\title{
MUTAGENESIS OF NOVEL CLOSTRIDIAL FUSANTS FOR ENHANCED GREEN BIOBUTANOL PRODUCTION USING RENEWABLE AND SUSTAINABLE FEEDSTOCK
}

\author{
by \\ Pallavi Roy
}

B. Eng, Chemical Engineering, Birla Institute of Technology and Science, Pilani, India

\author{
A Thesis \\ presented to Ryerson University \\ in partial fulfilment of the requirements \\ for the degree of \\ Master of Applied Science \\ in the program of \\ Environmental Applied Science and Management \\ Toronto, Ontario, Canada, 2014 \\ CPallavi Roy, 2014
}




\section{AUTHOR'S DECLARATION FOR ELECTRONIC SUBMISSION OF A THESIS}

I hereby declare that I am the sole author of this thesis. This is a true copy of the thesis, including any required final revisions, as accepted by my examiners.

I authorize Ryerson University to lend this thesis to other institutions or individuals for the purpose of scholarly research.

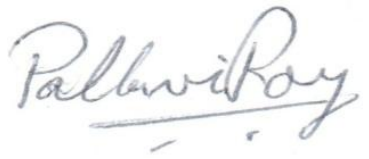

Pallavi Roy

I further authorize Ryerson University to reproduce this thesis by photocopying or by other means, in total or in part, at the request of other institutions or individuals for the purpose of scholarly research.

I understand that my thesis may be made electronically available to the public.

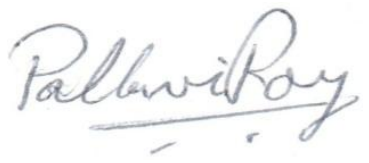

Pallavi Roy 


\title{
ABSTRACT \\ UV AND CHEMICAL MUTAGENESIS OF NOVEL CLOSTRIDIAL FUSANTS FOR ENHANCED GREEN BIOBUTANOL PRODUCTION USING AGRICULTURE RESIDUES AND ALGAE IN FEEDSTOCK
}

\author{
Pallavi Roy \\ Master of Applied Science \\ Environmental Applied Science and Management \\ Ryerson University
}

2014

Biobutanol was produced in the present work through Simultaneous Saccharification and Fermentation (SSF) of cellulosic feedstock (i.e. wheat straw (WS)) and algal biomass. Novel Clostridial fused strains developed earlier underwent mutagenesis for strain enhancement using UV and chemical mutagen (ethyl methanesulphonate). Results for mutated strains showed higher biobutanol production of $14.6 \mathrm{~g} / \mathrm{L}$, with total acetone, biobutanol and ethanol (ABE) yield of 0.6 $\mathrm{g} / \mathrm{g}$. Moreover, mutated strains showed tolerance to biobutanol toxicity at $15 \mathrm{~g} / \mathrm{L} ; \sim 15 \%$ increase over literature values. Algal biomass was pre-treated using different thermal, chemical and enzymatic pre-treatments to define its biobutanol production potential compared to WS. A total sugar concentration of $26.4 \mathrm{~g} / \mathrm{L}$ and glucose concentration of $12.48 \mathrm{~g} / \mathrm{L}$ was obtained with enzymatic pre-treatment. Biobutanol production through SSF of algal biomass showed maximum concentration of biobutanol of $7.52 \mathrm{~g} / \mathrm{L}$ with a total ABE yield of $0.48 \mathrm{~g} / \mathrm{g}$.

Keywords: Biobutanol, Mutation, Wheat Straw, Algae, Simultaneous Saccharification and Fermentation (SSF) 


\section{ACKNOWLEDGMENTS}

I would like to express my sincere gratitude to my supervisor, Dr. Yaser Dahman from Department of Chemical Engineering at Ryerson University, for his guidance, assistance, encouragement and support throughout the successful completion of this study.

I would also like to thank the Department of Environmental Applied Science and Management for giving me this opportunity and funding support for my research. I would also like to acknowledge Dr. Ronald Pushchak, whose inputs, advice and suggestions immensely benefitted this research; Dr. Michael Bardecki, Dr. Lynda McCarthy for their inputs and help during my study. I would like to mention Elias Chu, Isabella Fernandes, and Alison MacLeod, Ryerson University staff, for their support and guidance during my masters; Ali Hemmati and Daniel Boothe, Engineering Technologists of the Department of Chemical Engineering, for their technical support and assistance on my experimental setup and other laboratory materials and technical help. I would also like to thank Shawn Mcfadden for his guidance and teachings of the HPLC analytical method and usage of the machine.

Furthermore, I would like to thank my colleagues Banafsheh Mohtasebi, Kashif Seyed, Hamza Nakhoda, Wahib Al Abdallah, Wendy Stone and Ciro LeCompte for their help in troubleshooting, support and advice.

Finally, I would also like to express my sincere appreciation to my parents for their unconditional love, support and guidance. 
AUTHOR'S DECLARATION FOR ELECTRONIC SUBMISSION OF A THESIS ........... ii

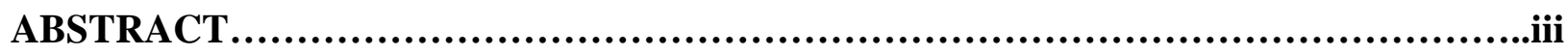

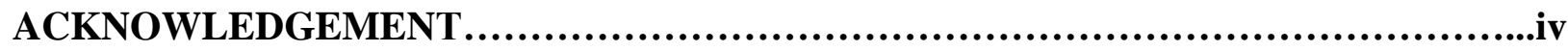

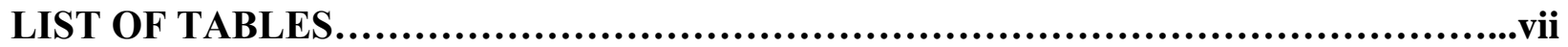

LIST OF FIGURES.......................................................................viii

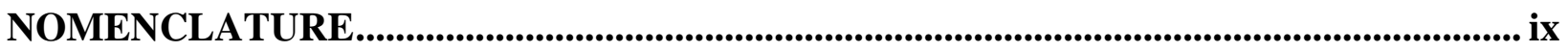

ACRONYMS

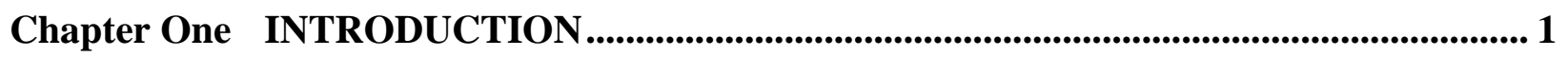

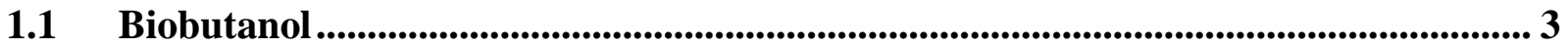

1.2 Objectives......................................................................................................................................... 4

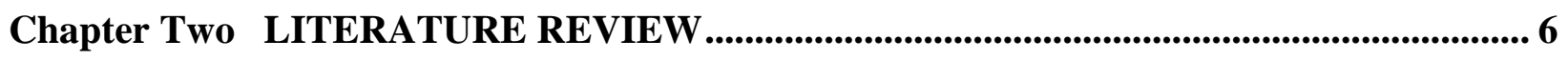

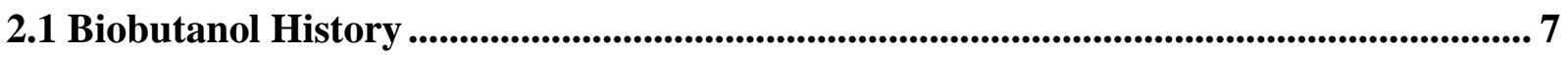

2.2 Energy Return on Investment ...................................................................................................8 8

2.3 Agricultural Biomass as Feedstock......................................................................................9

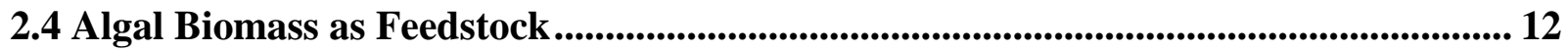

2.4.1 Uses of Algal Biomass ................................................................................................... 13

2.4.2 Advantages of Using Algal Biomass ....................................................... 15

2.4.3 Cultivation System for Algae ....................................................................................... 17

2.4.4 Algae Based Bioenergy Products ............................................................................ 21

2.4.5 Biorefinery of Algae ................................................................................................................ 23

2.5 Pre-treatment of Cellulosic Feedstock................................................................................ 24

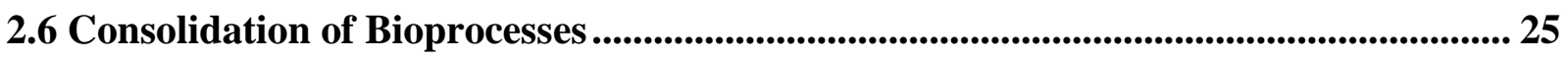

2.7 Acetone Butanol Ethanol (ABE) Fermentation Process .............................................. 27

2.8 Clostridial Strain Development for Biobutanol Production ............................................ 30

2.8.1 Protoplast Fusion Technology ............................................................................... 31

2.8.2 Mutagenesis of Bacterial strains...................................................................................... 33

2.8.3 Oxygen Tolerance ..................................................................................... 35

Chapter Three MATERIALS AND METHODS.......................................................................... 36

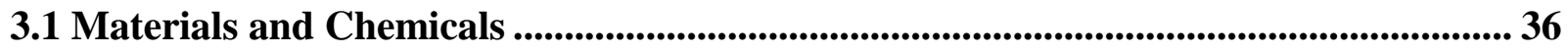

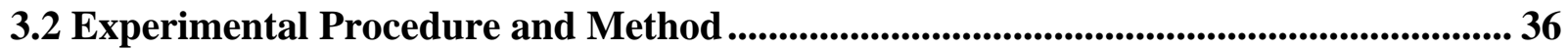


3.2.1 Culture Conditions and Medium Preparation ........................................................... 38

3.2.2 Mutagenesis Study .............................................................................................. 39

3.2.3 Biobutanol Production in Batch SSF using WS as Feedstock ............................. 41

3.2.4 Biobutanol Production in Batch SSF using Algal Biomass................................... 42

3.2.5 Oxygen Tolerance Study .................................................................................................... 44

3.3 Analytical Methods ........................................................................................................................ 44

3.3.1 High Performance Liquid Chromatography (HPLC)............................................ 45

3.3.2 Cell Count and Growth Rate Calculations............................................................... 46

3.4 Biomass Composition Calculation ............................................................................ 47

3.5 Error Analysis ............................................................................................................. 48

Chapter Four RESULTS AND ANALYSIS............................................................................... 51

4.1 Mutagenesis of Bacterial Strains and Production of Biobutanol...................................... 51

4.2 Algal Hydrolysis and Biobutanol Production Studies ...................................................... 67

4.3 Oxygen Tolerance Studies ................................................................................................. 75

Chapter Five CONCLUSIONS AND RECOMMENDATIONS ......................................... 79

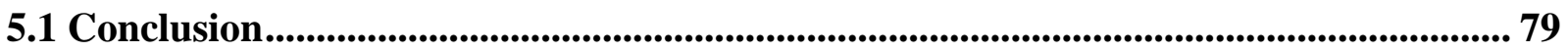

5.2 Future Study Recommendations .................................................................................................... 80

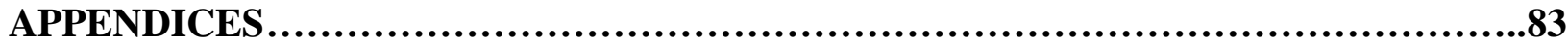

Appendix A Chemicals used in the current study ...................................................................... 83

Appendix B Sugars, ABE, and acids Standard Calibration Curves (HPLC)..................... 84

Appendix $\mathrm{C}$ Raw data for mutagenesis, sugar profile, $\mathrm{ABE}$ and acids produced during SSF of WS and Algal biomass ........................................................................................................ 89

Appendix D Error calculation for SSF study raw data ............................................................. 96

Appendix E Error calculation for Algal Bio-refinery study .................................................... 100

REFERENCE.................................................................................................................................... 102 


\section{LIST OF TABLES}

Table 1.1 Properties of common fuels 4

Table 2.1 Yield of crops and crop residues in Canada 11

Table 2.2 Lipid content of different microalgae species $\quad 13$

Table 2.3 Productivity of selected oil crops $\quad 15$

Table 2.4 Concentration of $\mathrm{ABE}$ and acids produced using the protoplast fused strains at 32 $45^{\circ} \mathrm{C}$

Table 3.1 Strain nomenclature for further study $\quad 40$

Table 3.2 Hydrolysis of algae under different conditions $\quad 43$

Table 3.3 Different pre-treatment methods selected before SSF 44

Table 4.2 Individual sugar concentrations produced by mutated strains during SSF of WS 61

Table 4.2 ABE and acid concentrations produced by mutated strains during SSF of WS 64

Table 4.3 Comparison of sugar consumption and ABE yield for all strains during SSF of 67

WS

Table 4.4 Sugar concentrations for different pre-treatment conditions from algae 68

Table 4.6 Sugar concentrations obtained from hydrolysis of WS and algal biomass $\quad 71$

Table 4.6 Composition of algal biomass in the present study compared to WS and Corn 72

Stover compositions from literatures

Table 4.7 ABE production values using algal biomass as feedstock at 120 hours of SSF 73

Table 4.8 Butanol and ABE yield comparison from SSF experiments using WS and algal 74

biomass as feedstocks

Table 4.9 Productivity of cellulosic feedstocks as determined from literature 75

Table A.1 Chemicals used in the study $\quad 83$

Table D.1 Total sugar profile for strain S1 for three SSF experiments 96

Table D.2 Total sugar profile for strain S2 over three SSF experiments 96

Table D.3 Sugar profile for strain S3 over three SSF experiments 97

Table D.4 Sugar profile for strain S4 over three SSF experiments 97

Table D.5 Sugar profile for strain S5 over three SSF experiments 98

Table D.6 Sugar profile for strain S6 over three SSF experiments 98

Table D.7 Sugar profile for strain S7 over three SSF experiments 99

Table E.1 Total sugar concentration for all samples over three hydrolysis experiments $\quad 100$

Table E.2 Total butanol concentration for all samples over three SSF experiments $\quad 101$ 


\section{LIST OF FIGURES}

Figure 1.1 Categorisation of biofuels based on feedstock 2

$\begin{array}{ll}\text { Figure 0.2 Energy return on investment } & 7\end{array}$

Figure 2.3 Structure of lignocellulosic biomass $\quad 9$

Figure 2.3 Raceway pond schematic $\quad 19$

Figure 2.4 Overview of energy products from algae $\quad 21$

Figure 2.5 Effect of pre-treatment on lignocellulosic biomass 27

Figure 2.6 Diagram of fuel ethanol production from lignocellulosic biomass 29

Figure 2.7 ABE Pathway $\quad 30$

Figure 0.4 Flow chart of experimental procedure 36

Figure 4.1 Cell count after mutagenesis with EMS $\quad 52$

Figure 4.2 Cell count of EMS mutated cells in contact with 15g/L of Butanol 52

Figure 4.3 Surviving fraction and Relative frequency of induced mutation from EMS 53

Figure 4.4 Cell count after mutagenesis with UV radiation $\quad 54$

Figure 4.5 Cell count of EMS mutated cells in contact with 15g/L of Butanol 54

Figure 4.6 Surviving fraction and Relative frequency of induced mutation from UV 55

Figure 4.7 Individual sugar consumption profile of strain S1 during SSF of WS 56

Figure 4.8 Sugar concentration profile by strain S2 during SSF of WS 57

Figure 4.9 Sugar concentration profile by strain S3 during SSF of WS 59

Figure 4.10 Sugar concentration profile by strain S4 during SSF of WS 59

Figure 4.11 Sugar concentration profile by strain S5 during SSF of WS 59

Figure 4.12 Sugar concentration profile by strain S6 during SSF of WS 59

Figure 4.13 Sugar concentration profile by strain S7 during SSF of WS 59

Figure 4.14 Cell concentrations of different strains over 120 hours of SSF 63

Figure 4.15 Cell count for samples grown in aerobic conditions compared with sample 76

Figure 4.16 ABE production for SSF in aerobic condition compared to SSF in anaerobic 77

Figure B.1 HPLC calibration curve for Glucose $\quad 84$

Figure B.2 HPLC calibration curve for Galactose $\quad 84$

Figure B.3 HPLC calibration curve for Xylose $\quad 85$

Figure B.4 HPLC calibration curve for Mannose $\quad 86$

Figure B.5 HPLC calibration curve for Arabinose $\quad 86$

Figure B.6 HPLC calibration curve for Acetone $\quad 87$

Figure B.7 HPLC calibration curve for Biobutanol $\quad 87$

Figure B.8 HPLC calibration curve for Ethanol $\quad 88$

Figure B.9 HPLC calibration curve for Acetic acid $\quad 88$

Figure B.10 HPLC calibration curve for Butyric acid 89 


\section{NOMENCLATURE}

\%RSD percent relative standard deviation

$\mathrm{Cb} \quad$ Clostridium beijerinckii

$\mathrm{CbCt} \quad$ Fused clostrial strain: $\mathrm{Cb}$ and $\mathrm{Ct}$

$\mathrm{c}_{\mathrm{h}} \quad$ the specific heat $\left(\mathrm{J} / \mathrm{g} .{ }^{\circ} \mathrm{C}\right)$

$\mathrm{Ct} \quad$ Clostridium thermocellum

$\mathrm{m} \quad$ mass of the substance $(\mathrm{g})$

X data point

$\bar{x} \quad$ sample mean value

\section{ACRONYMS}

$\begin{array}{ll}\text { ABE } & \text { acetone-biobutanol-ethanol } \\ \text { CBM } & \text { clostridium basal medium } \\ \text { CBP } & \text { consolidated bioprocessing } \\ \text { CS } & \text { corn stover } \\ \text { EMS } & \text { Ethyl methane sulphonate } \\ \text { ERoI } & \text { energy return on investment } \\ \text { GHG } & \text { greenhouse gas } \\ \text { HPLC } & \text { high performance liquid chromatography } \\ \text { PEG } & \text { polyethylene glycol } \\ \text { SSF } & \text { simultaneous saccharification and fermentation } \\ \text { STDEV } & \text { standard deviation } \\ \text { UV } & \text { ultra violet } \\ \text { WS } & \text { wheat straw }\end{array}$




\section{CHAPTER ONE INTRODUCTION}

Rising fossil fuel and food prices, and increasing international pressure on climate change mitigation, have intensified the search for a renewable source of energy (Coyle, 2007). A biofuel is a type of renewable and green fuel whose energy is derived from biological carbon fixation. Biofuels include fuels derived from biomass conversion, as well as solid biomass, liquid fuels like ethanol, soybean oil and various biogases. Biofuels are being looked upon as not only an effective alternative energy source but also as a means of lowering greenhouse gas (GHG) emissions (Walsh et al., 2003; Sorda et al., 2010).

A distinction is made between primary and secondary biofuels. Primary biofuels consist of fuel wood, wood chips and pellets where organic materials are used in an unprocessed form, primarily for heating, cooking or electricity production. Secondary biofuels result from processing of biomass and include liquid biofuels such as ethanol and biodiesel that can be used in vehicles and industrial processes. Liquid Biofuels are categorised into first, second and third generation biofuels (Phillipidis et al., 1993; Carere et al., 2008; Sims et al., 2010; Nigam and Singh, 2011). The primary distinction between them is the feedstock used. The classification is illustrated in Figure 1.1 


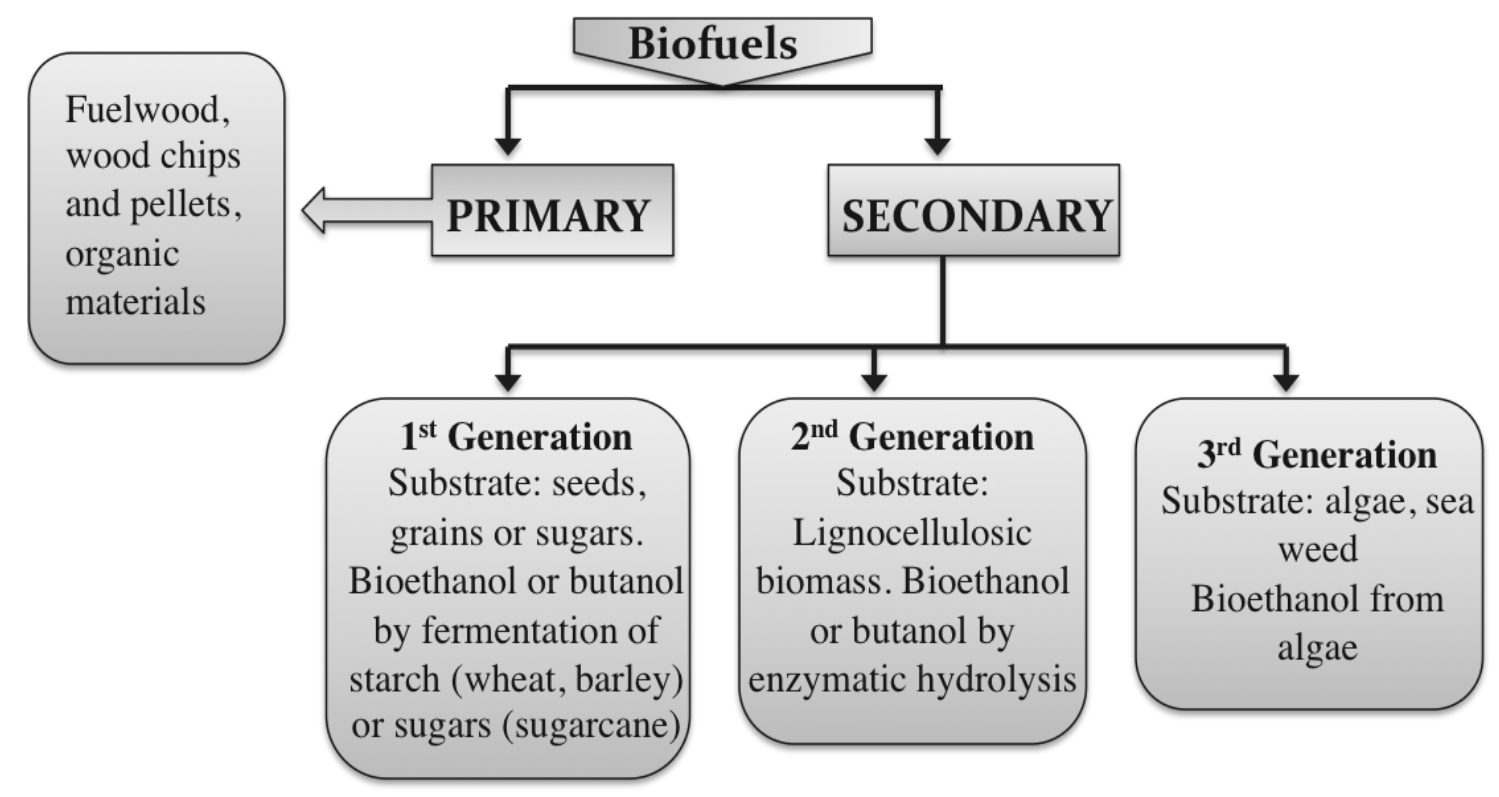

Figure 1.1 Categorisation of biofuels based on feedstock

The first-generation of secondary biofuels has generally been produced from sugars, grains or seeds and require a simple process to convert it into biofuel. Ethanol from corn (in USA) or sugarcane (in Brazil) is the most common and well known of the first generation fuels. It is mixed with gasoline in many countries around the world and is very close to being cost comparative to gasoline (Balat and Balat, 2009). However, Ethanol was first mixed with gasoline in the US in the 1990s as a replacement for methyl-ter-butyl ether (MTBE) as an additive to oxygenate gasoline, as MTBE had issues of water contamination (Dewsbury et al., 2003). Then seeing the potential for rural development by using agricultural produce (mostly corn) for fuel generation, ethanol production and the biofuel mandate received a boost, in terms of government programs, investment and subsidies in the US (Tyner and Taheripour, 2008).

Tyner et al., (2010) comments that the sustainability and 'green' nature of this generation is questionable due to its conflict with the food supply and changes in land use. Biofuels are 
technically supposed to reduce GHG emissions. However, the process of growing the crops, making fertilizers and pesticides, and processing the biomass into fuel consumes a lot of energy. So much energy is used that there is debate about whether ethanol from corn actually provides more energy than is required to grow and process it. Also, because much of the energy used in production comes from coal and natural gas, biofuels don't replace as much oil as they use. Then there is the food vs fuel debate. Converting edible crops into fuel can affect their prices (Thompson et al., 2009). Also changes in land use add to indirect GHG emissions (Tyner et al., 2010).

The issues with first generation biofuels have led to the development of second-generation biofuels. The second generation biofuels are produced from biological or thermochemical processing of ligno-cellulosic biomass. This generation has a significant advantage over the previous generation as it utilizes the non-edible residues of food crops like wheat and corn. However, the production of second-generation biofuels requires not only sophisticated processing technologies but also more investment of resources per unit of production accompanied by large-scale facilities (Nigam and Singh, 2011).

\subsection{Biobutanol}

Butanol formed from plant material is often referred to as biobutanol. It is chemically similar to butanol produced from petroleum. Butanol, because of its longer hydrocarbon chain has a $30 \%$ more energy content than ethanol and is closer to gasoline in properties as apparent in Table 1.1. Butanol, in its pure form can be blended in any concentration with gasoline unlike ethanol which can only be blended up to $85 \%$ (Dürre, 2007). The introduction of butanol into the existing car engines as a combustible fuel requires minimal modification to the engine technology. Biobutanol has been demonstrated to work in some vehicles designed for use with gasoline 
without any modification (Savage, 2011). The product's lower vapour pressure makes it safer to handle. Butanol is not hygroscopic (water absorbent) which allows blending with gasoline at a refinery way ahead of storage and distribution. This is in stark contrast to ethanol, which requires blending to occur shortly before distribution due to its hygroscopic nature (Dürre, 2007).

Table 1.1 Properties of common fuels (Qureshi et al., 2007)

\begin{tabular}{|c|c|c|c|c|c|c|}
\hline Fuel & $\begin{array}{c}\text { Energy } \\
\text { density }\end{array}$ & $\begin{array}{c}\text { Air-fuel } \\
\text { ratio }\end{array}$ & $\begin{array}{c}\text { Specific } \\
\text { energy }\end{array}$ & $\begin{array}{c}\text { Heat of } \\
\text { vaporization }\end{array}$ & RON $^{\mathbf{1}}$ & MON $^{\mathbf{2}}$ \\
\hline Gasoline & $32 \mathrm{MJ} / \mathrm{L}$ & 14.6 & $\begin{array}{c}2.9 \mathrm{MJ} / \mathrm{kg} \\
\text { air }\end{array}$ & $0.36 \mathrm{MJ} / \mathrm{kg}$ & $91-99$ & $81-89$ \\
\hline Butanol & $\mathbf{2 9 . 2 ~ M J / L}$ & $\mathbf{1 1 . 2}$ & $\begin{array}{r}\mathbf{3 . 2} \mathbf{~ M J} / \mathbf{k g} \\
\mathbf{a i r}\end{array}$ & $\mathbf{0 . 4 3} \mathbf{M J} / \mathbf{k g}$ & $\mathbf{9 6}$ & $\mathbf{7 8}$ \\
\hline Ethanol & $19.6 \mathrm{MJ} / \mathrm{L}$ & 9.0 & $\begin{array}{c}3.0 \mathrm{MJ} / \mathrm{kg} \\
\text { air }\end{array}$ & $0.92 \mathrm{MJ} / \mathrm{kg}$ & 129 & 102 \\
\hline Methanol & $16 \mathrm{MJ} / \mathrm{L}$ & 6.5 & $\begin{array}{r}3.1 \mathrm{MJ} / \mathrm{kg} \\
\text { air }\end{array}$ & $1.2 \mathrm{MJ} / \mathrm{kg}$ & 136 & 104 \\
\hline
\end{tabular}

${ }^{1}$ Research Octane Number: determined with a test engine running at a low speed of $600 \mathrm{rpm}$

${ }^{2}$ Motor Octane Number: determined with a test engine running at a low speed of $900 \mathrm{rpm}$

\subsection{Objectives}

From the discussion presented in the earlier section, it is revealed that $2^{\text {nd }}$ generation biobutanol, could play a coherent role in achieving sustainable energy management goals. Though cellulosic biofuels are renewable, the impact on agriculture, food systems, land use system and the environment are potentially significant. Most importantly cellulosic biobutanol is not yet 
economically competitive with petroleum or first generation ethanol. Thus, the main objective of this study is to enhance biobutanol production and yield by investigating metabolic engineering of bacterial strains and selection of renewable and sustainable feedstock.

The main focus of the present study was to determine whether UV irradiation and treatment with an appropriate chemical mutagen (ethyl methane sulphonate) are the means of producing desirable mutants of a novel fused clostridial strain that was developed in our laboratory at Ryerson University. Following that, production of biobutanol was examined using agriculture residues of WS and algae to determine their suitability as feedstocks. Both biomass feedstock types were pretreated and hydrolysed using different methods prior to utilization. This thesis, detailing the work done in the present study to answer the objectives mentioned above, is structured in five chapters as follows:

Chapter One - introduces the reader to the thesis topic and motivation to conduct the study and gives a brief description of the document.

Chapter Two - presents the literature review on the factors associated with mutagenesis of bacterial strains, cellulosic feedstock selection and SSF conducted to produce biobutanol.

Chapter Three - describes the materials and methods that employed in the experimental work.

Chapter Four - presents the experimental results and an analysis of the mutation study, growth condition study focused on aerotolerance of bacterial strain, algal hydrolysis and SSF of cellulosic feedstock using mutated strains.

Chapter Five - gives general concluding remarks, along with recommendations for future work. 


\section{CHAPTER TWO LITERATURE REVIEW}

\subsection{Biobutanol History}

Biobutanol is produced using the Acetone Biobutanol Ethanol (ABE) pathway. The ABE pathway was discovered by Louis Pasteur and it was the main pathway used for most of the late 1800s to early 1900 s for the production of biobutanol. During prohibition there was an amyl alcohol shortage which was an important solvent for the paint industry (Dürre, 2007). Biobutanol proved to be a perfect alternative for amyl alcohol and several ABE production plants were opened in different countries to fulfill the industrial requirements. Therefore, until 1950 two thirds of world's biobutanol supply came from biological fermentation. Interest in the fermentation process eventually declined, owing to competition from cheaper chemical synthetic processes using petrochemical feedstock (Awang et al., 1988). From that point until 2000s, biobutanol was produced as an intermediate in petroleum distillation. Recently it has gained attention again as an alternative to ethanol as transportation fuel. BP and DuPont have proposed to restart an industrial $\mathrm{ABE}$ fermentation plant to provide biobutanol to Great Britain (Dürre, 2007). BP is currently working towards producing more effective microbes that convert both corn and other cellulosic feedstocks into biobutanol. Denver based Gevo Inc. is lining up financing for five more ethanol plants for to be converted to butanol production. These new biobutanol capacities could produce up to 200 million gallons per year if the company succeeds in raising finances (Scotia Captial Inc, 2010). As mentioned above, due to an interest in biobutanol as a fuel source the ABE process is again gaining research interest. The goal of most 
researchers now is to improve the process by developing enhanced bacterial strains, increase yields and use of novel feedstock.

\subsection{Energy Return on Investment}

Energy return on investment (ERoI) is the ratio of the energy delivered by a process to the energy used directly and indirectly in that process. The history of the development of human civilization and its material standard of living is directly linked to successive access to and development of fuel sources with increasingly greater ERoI. The transitions from basic energy sources such as plant biomass, and animals, to wind and waterpower, to fossil fuels and electricity enabled increases in per capita yield due to increases in the quantity of fuel available to produce non-energy goods. The evolution to higher ERoI fuels also aided social and economic improvement as increasingly less of the total available energy was used in the energy securing process, meaning more fuel was available to support other activities.

One way to evaluate the production of biofuels is to calculate the energy return on (energy) investment (ERoI), which is similar to the net energy ratio (NER), and can be used to assess the feasibility and sustainability of an energy source.

$E_{\text {out }}$ is the energy in a certain amount of biofuel output, and $E_{\text {in, }}$ often from non-renewable resources, is energy input to the manufacturing process for that same amount of biofuel.

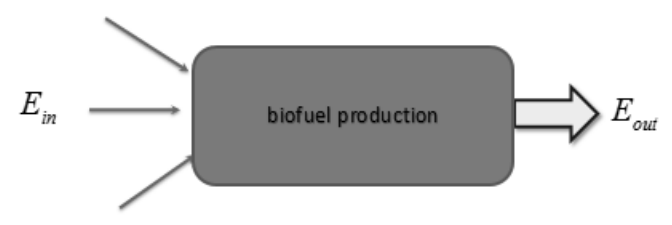

Figure 2.1 Energy return on investment 
As this term is a ratio, as long as $E_{\text {out }}$ and $E_{i n}$, are both of the same unit, the ERoI is unitless. ERoI tells us how any energy production technology utilises the non-renewable energy to produce it. One is an important threshold value for ERoI. If ERoI $<1$, then the total energy in the biofuel is less than the non-renewable energy that went into it, and we might as well have made direct use of the non-renewable fuels instead. If ERoI > 1, then we have managed to capture at least some renewable energy value with our non-renewable investment.

Since ERoI is the amount of energy produced divided by the amount of energy required for that production, it has been used to characterize many resources. For example, the ERoI for production of conventional oil and gas, coal, wind energy, and corn ethanol has been estimated to be $\sim 15, \sim 80, \sim 19$, and $\sim 1$, respectively (Shapouri et al., 2002; Cleveland, 2005; Farrell et al., 2006; Kubiszewski et al., 2010). As is evidenced, biofuels have a long way to go in terms of competitive ERoI when compared to conventional sources. This identifies a need for more research in the field of renewable energy.

\subsection{Agricultural Biomass as Feedstock}

Recent technologies for agricultural biomass conversion (through their hydrolysate solutions) have proven that agricultural wastes have enough carbon sources to produce value-added biobased products (Dahman et al., 2010).

Agriculture biomass is composed mainly of three bio-based chemicals called cellulose (35-48 \%dry wt), hemicellulose (22-48\% dry wt) and lignin (15-27\% dry wt) (Scurlock, 2001; Sun and Cheng, 2005). Together, they are called lignocellulose, a composite material of rigid cellulose fibers embedded in a cross-linked matrix of lignin and hemicellulose that bind the fibers. Lignocellulose material is by necessity resistant to physical, chemical, and biological attack, but 
it is of interest to bio-refining because the cellulose and hemicellulose can be broken down through a hydrolysis process to produce fermentable, simple sugars.

Cellulose is a very large polymer molecule composed of many hundreds or thousands of glucose molecules (polysaccharide). Unlike starch, the glucose monomers of cellulose are linked together through bonds resulting in tightly packed and highly crystalline structures that are resistant to hydrolysis. Therefore, pre-treatment of lignocellulosic biomass before enzymatic hydrolysis is a vital step. Hemicellulose consists of short, highly branched, chains of sugars. It contains fivecarbon sugars (usually D-xylose and L-arabinose) and six-carbon sugars (D-galactose, D-glucose and D-mannose) and uronic acid. Hemicellulose is amorphous and relatively easy to hydrolyze to its constituent sugars (Vassilev et al., 2010). Lignin is a polymer constructed of noncarbohydrate, alcohol units that are not fermentable such as p-coumaryl alcohol, coniferyl alcohol, and sinapyl alcohol (Vassilev et al., 2010). While cellulose and hemicellulose contribute to the amount of fermentable sugars for ethanol production, products of lignin degradation are recognized as a potential source of microbial inhibitors (Ezeji et al., 2007). Figure 2.2 visually represents the structure of lingo-cellulosic biomass.

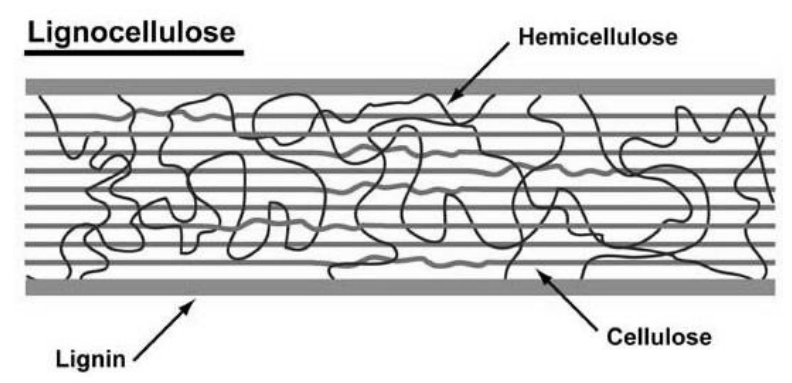

Figure 2.2 Structure of lignocellulosic biomass (USDA Agricultural Research Service)

Table 2.1 lists the amount of biomass generated from agricultural crop residues in Canada. Almost 14.6 Million tonnes of Carbon per year (Mt C/yr) with an energy value of $0.6 \mathrm{EJ}$ 
(exajoule), is recoverable from the field at the same time preserving soil integrity and accounting for losses during harvest process. However, traditional uses reduce the current availability to 8.6 Mt C/yr with an energy potential of 0.3 EJ (Woods and Layzell., 2003).

From the Table 2.1, (Woods and Layzell, 2003) we can see the immense energy potential associated with wheat straw in Canada. Out of a total production of 26.7 million oven-dried tonnes per year (M ODT/yr) of wheat straw, more than $50 \%$ of it is recoverable (after harvest) contributing to a potential energy contribution of $0.241 \mathrm{EJ} /$ year. However, currently only $7.46 \mathrm{M}$ ODT/year is available, contributing to about $0.12 \mathrm{EJ} / \mathrm{year}$, roughly half of its maximum potential. The reader might also realize from the table the need to invest in wheat straw as substrate in Canada due to large-scale production (of roughly more than a quarter of current crop production) coming from wheat crops.

Also previous attempts at producing biobutanol from Wheat Straw Hydrolysate (WSH) have been very successful (Qureshi et al., 2008). WS contains cellulose, hemicellulose, and low amount of lignin that makes it noticeable among agricultural residues (Harper and Lynch, 1981). Other studies by Qureshi et al., (2007) and Qureshi and Ezeji (2008) have shown that not only was the fermentation more rapid than the ones in which glucose (as a substrate) was exclusively used, but also there was an absence of inhibition due to salts or other inhibitory products. 
Table 2.1 Yield of crops and crop residues in Canada (Woods and Layzell, 2003)

\begin{tabular}{|c|c|c|c|c|c|c|c|c|c|}
\hline & Yield of $\mathrm{Cr}$ & ps and Crop Re & idues & & & & Currently & Available 1 & sidues \\
\hline Crop & $\begin{array}{l}\text { Total } \\
\text { Production }\end{array}$ & Straw/Stover & $\begin{array}{l}\text { Sustainably } \\
\text { Removable } \\
\text { Residues }\end{array}$ & Recoverab & e SRR & $\begin{array}{l}\text { Energy } \\
\text { Potential of }\end{array}$ & $\begin{array}{l}\text { Amount } \\
\text { Available }\end{array}$ & $\begin{array}{l}\text { Carbon } \\
\text { content }\end{array}$ & $\begin{array}{l}\text { Energy } \\
\text { potential }\end{array}$ \\
\hline Units & M ODT/yr ${ }^{a}$ & M ODT/yr & M ODT/yr & M ODT/yr & $\mathrm{MtC} / \mathrm{yr}$ & $\mathrm{EJ} / \mathrm{yr}^{\mathrm{b}}$ & $\mathrm{M} \mathrm{ODT} / \mathrm{yr}$ & $\mathrm{Mt} \mathrm{C} / \mathrm{yr}^{\mathrm{c}}$ & $\mathrm{EJ} / \mathrm{yr}$ \\
\hline Wheat & 20.6 & 26.7 & 21.4 & 14.97 & 6.74 & 0.241 & 7.49 & 3.37 & 0.12 \\
\hline Barley & 10.8 & 10.8 & 8.68 & 6.07 & 2.73 & 0.098 & 3.04 & 1.37 & 0.049 \\
\hline Oats & 2.7 & 2.7 & 2.15 & 1.51 & 0.68 & 0.024 & 0.75 & 0.34 & 0.012 \\
\hline Grain Corn & 8.3 & 8.3 & 6.65 & 3.33 & 1.5 & 0.054 & 3.33 & 1.5 & 0.054 \\
\hline Canola & 4.9 & 4.9 & 3.94 & 2.76 & 1.24 & 0.044 & 2.76 & 1.24 & 0.044 \\
\hline Soybeans & 1.6 & 1.6 & 0.33 & 0.16 & 0.07 & 0.003 & 0.16 & 0.7 & 0.003 \\
\hline Flaxseed & 0.72 & 0.72 & 0.57 & 0.4 & 0.18 & 0.006 & 0.2 & 0.9 & 0.003 \\
\hline Rye & 0.23 & 0.23 & 0.18 & 0.13 & 0.57 & 0.002 & 0.06 & 0.29 & 0.001 \\
\hline Fodder Corn & 5.2 & 0 & 0 & 0 & 0.26 & 0.009 & 0.26 & 0.12 & 0.004 \\
\hline Tame hay & 23.1 & 0 & 0 & 0 & 1.157 & 0.041 & 1.16 & 0.52 & 0.019 \\
\hline Totals & 78.27 & 56.09 & 43.89 & 29.33 & 14.62 & 0.523 & 17.79 & 8.64 & 0.309 \\
\hline
\end{tabular}

${ }^{a}$ M ODT/yr represents Million Oven dried tonnes per year

${ }^{\mathrm{b}} \mathrm{EJ} / \mathrm{yr}$ is Exajoule per year. $1 \mathrm{EJ}=10^{18} \mathrm{~J}$

${ }^{\mathrm{c}} \mathrm{MtC} / \mathrm{yr}$ represents Million tonnes of Carbon per year 


\subsection{Algal Biomass as Feedstock}

Recently algae have been getting a lot of consideration as a potential biofuel feedstock. Interest on algae is continuously growing because algae has potential to meet global transportation fuel demand (Szulczyk and McCarl, 2010). Moreover, microalgae has high productivity per unit area in contrast to other crops and algae do not require field to grow. Algae produce 2,500,000 Litres $/ \mathrm{km}^{2}$ of oil whereas soybeans produce 59,000 Litres $/ \mathrm{km}^{2}$ of oil at medium productivity per annum (Pienkos and Darzins, 2009). However, biodiesel production from algae oil is not economically competitive, yet. Therefore, taking a bio-refinery approach and refining valuable by-products to increase avenues of revenue generation can improve this.

Algae are autotrophic organism which range from unicellular to multicellular forms. It utilizes sunlight to reduce $\mathrm{CO}_{2}$ to biodiesels (main product), foods, fertilizers and other useful products i.e. energy, proteins, animal feed, pharmaceuticals etc. Microalgae has various advantages over other agricultural raw material. Most significant is, can be grown anywhere and every season because algae has variety of spices that have different properties and adaptations. It can grow in open ponds, sea water, fresh water, deserts, arid lands etc. For growth of algae some parameters such as $\mathrm{pH}$, light, salinity, temperature and quality of ingredients are important (Demirbas and Demirbas, 2011). Table 2.2 illustrates the lipid content of different microalgae. The lipid content of different microalgae vary substantially, thus the choice of microalgae species as feedstock becomes critical. 
Table 2.2. Lipid content of different microalgae species (Food and Agriculture Organisation [FAO], 2009)

\begin{tabular}{|l|l|}
\hline Microalgae & Oil content $(\%$ w/w) \\
\hline Botryococcus braunii & $25-75$ \\
\hline Chlorella protothecoides & $14-57$ \\
\hline Crypthecodinium cohnii & $20-51$ \\
\hline Dunaliella tertiolecta & $16-71$ \\
\hline Nannochloris sp. & $20-56$ \\
\hline Neochloris oleoabundans & $29-65$ \\
\hline Phaeodactylum tricornutum & $18-57$ \\
\hline Schizochytrium sp. & $50-77$ \\
\hline Skeletonema coastatum & $13-51$ \\
\hline
\end{tabular}

\subsubsection{Uses of Algal Biomass}

The importance of exploring new options offered by algae cultivation is driven by the fact that different species of algae are very efficient at converting light, water and carbon dioxide $\left(\mathrm{CO}_{2}\right)$ into biomass in a system that does not necessarily require agricultural land. Algae can be grown in freshwater as well as seawater and can also grow in wastewater. Depending on the species and cultivation conditions, algae can contain extremely high percentages of lipids or carbohydrates that are easily converted into a whole range of biofuels including biodiesel or bioethanol and biobutanol. Moreover, the remaining biomass, mostly protein and carbohydrate, may be processed into many other products such as: foods, chemicals, medicines, vaccines, minerals, animal feed, fertilizers, pigments, salad dressings, ice cream, puddings, laxatives and skin creams (Subhadra and Edwards, 2011). Algae- based products can serve as an alternative to a wide range of products that are currently produced from fossil resources or land-based agriculture, but without requiring high quality land and in some cases without requiring fresh water, with $\mathrm{CO}_{2}$ as the only carbon input. 
In recent years, biofuel production from algae has attracted the most attention among other possible products. This can be explained by the global concerns over depleting fossil fuel reserves and climate change. Furthermore, increasing energy access and energy security are seen as key actions for reducing poverty thus contributing to the Millennium Development Goals. Access to modern energy services such as electricity or liquid fuels is a basic requirement to improve living standards. One of the steps taken to increase access and reduce fossil fuel dependency is the production of biofuels. Biofuels are crucial especially because they are currently the only short-term alternative to fossil fuels for transportation. The so-called first generation biofuels are produced from agricultural feedstocks that can also be used as food or feed purposes. The possible competition between food and fuel makes it impossible to produce enough first generation biofuel to offset a large percentage of the total fuel consumption for transportation. As opposed to land-based biofuels produced from agricultural feedstocks, cultivation of algae for biofuel does not necessarily use agricultural land and requires only negligible amounts of freshwater (if any), and therefore competes less with agriculture than first generation biofuels. Combined with the promise of high productivity, direct combustion gas utilization, potential wastewater treatment, year-round production, biochemical content of algae and chemical conditions of their oil content can be influenced by changing cultivation conditions.

On the other hand, microalgae, as opposed to most plants, lack heavy supporting structures and anchorage organs, which pose some technical limitations to their harvesting. The real advantage of microalgae over plants lies in their metabolic flexibility, which offers the possibility of modification of their biochemical pathways (e.g. towards protein, carbohydrate or oil synthesis) and cellular composition (Tredici, 2010). 


\subsubsection{Advantages of Using Algal Biomass}

Algal biofuel has the potential to be the fuel of the future and meet energy demands. Algal biomass is an ideal feedstock due to its attractive properties like high productivity, reduced land use etc., which are explained in detail further in this section.

a) High productivity

As mentioned earlier, algae have high growth rates. Algae are the fastest growing plants in the worlds. They don't require herbicides and fungicides either, providing a cleaner growing environment and fewer emissions (Brennan and Owende, 2010). They have high levels of oil production, as evident in the Table 2.3 that lists oil yield for different feedstocks.

Table 2.3 Productivity of selected oil crops (Singh and Gu, 2010)

\begin{tabular}{|l|l|}
\hline \multicolumn{1}{|c|}{ Crop } & Oil Yield (L/Hectare) \\
\hline Corn & 172 \\
\hline Soyabean & 446 \\
\hline Canola & 1190 \\
\hline Rapeseed & 1190 \\
\hline Jatropha & 1892 \\
\hline Oil Palm & 5940 \\
\hline Microalgae (30\% oil w/w) & 58700 \\
\hline Microalgae (70\% oil w/w) & 136900 \\
\hline
\end{tabular}


b) Feedstock and land use

One of the main drawbacks of first generation fuels is the use of food crops for energy production. Using corn and other food products as a feedstock takes away from the amount of food available for consumption. Algae does not require the use of fertile land which could otherwise be growing food crops, and therefore has no impact on the food supply or food costs. In fact, depending on the cultivation methods, algae could be grown on land which does not serve any other purpose, such as brownfields, thereby increasing the carbon density of the land upon which it is grown (Zandi et al., 2011).

c) Water use

Another great advantage of algae is that it doesn't require huge amounts of fresh water to grow in (Pittman et al., 2011). In fact it can be grown in sea water and even waste water. Algae can be especially grown in wastewater to remove pollutants like nitrogen and phosphorus which are hard to remove (Christenson and Sims, 2011). This not only satisfies the nutritional needs of the algae but cleans the water as well.

d) Waste to energy

There are a number of industries that create large quantities of $\mathrm{CO}_{2}$ as a by-product of operation. Efforts have been made to integrate the algae biofuel creation process into these industries to stop the $\mathrm{CO}_{2}$ emissions at the source. "The microalgae Botryococcus braunii 765 is one strain which has shown that it is able to thrive in flue gas $\mathrm{CO}_{2}$ concentrations ranging from $2 \%-20 \%$ " (Ge et al., 2011). This makes it feasible for use at industrial plants. For example, Pond Biofuels has established an operation that utilizes the $\mathrm{CO}_{2}$ generated during the concrete manufacturing process as feedstock for algal growth. As for power plants fuelled by coal, literature states that 
conjoined algal biofuel production could lead to a net greenhouse gas avoidance of $26.3 \%$ (Brune et al., 2009).

Even though algae have these advantages, the main barrier to commercialization of algal biofuel remains the cost of cultivation. However, algae produce a variety of different products as and a good approach is to use the algae left over from fuel generation for co-products. The biomass left over after the oil has been extracted could also be used for applications such as livestock feed, fertilizer, or electricity production via direct burning or digester gas methane combustion (Brune et al., 2009). Also after extraction of lipids, the biomass can be used to produce biobutanol as another source of biofuels.

\subsubsection{Cultivation System for Algae}

Although not specific to biofuel production from algae, it is important to understand the basics of algae cultivation systems as this forms an important consideration in respect to algae costs. Systems which use artificial light requirement increase the energy demand, thus reducing the ERoI gained only systems using natural light are considered useful for large scale algae growth for commercial use. Seaweed has historically been harvested from natural populations or collected after washing up on shore. To a much lesser extent, a few microalgae have also been harvested from natural lakes by indigenous populations (FAO 2009). However, these practices are unlikely to contribute significantly to algal feedstock supply.

Artificial cultivation systems are mainly of three types: open, closed, and sea based cultivation systems. 


\section{a) Open cultivation system}

Cultivation of algae in open ponds has been extensively studied. Open ponds can be categorized into natural waters (lakes, lagoons, ponds) and artificial ponds or containers. The most commonly used systems include shallow big ponds, tanks, circular ponds and raceway ponds. One of the major advantages of open ponds is that they are easier to construct and operate than most closed systems. However, major limitations in open ponds include poor light utilization by the cells, evaporative losses, diffusion of $\mathrm{CO}_{2}$ to the atmosphere, and requirement of large areas of land. Furthermore, contamination by predators and other fast growing heterotrophs have restricted the commercial production of algae in open culture systems to only those organisms that can grow under extreme conditions. Also, due to inefficient stirring mechanisms in open cultivation systems, their mass transfer rates are very poor resulting to low biomass productivity (Johnson, 2009).

The ponds in which the algae are cultivated are usually what are called the "raceway ponds" illustrated in Figure 2.3. In these ponds, the algae, water \& nutrients circulate around a racetrack. With paddlewheels providing the flow, algae are kept suspended in the water, and are circulated back to the surface on a regular frequency. The ponds are usually kept shallow because the algae need to be exposed to sunlight, and sunlight can only penetrate the pond water to a limited depth. The ponds are operated in a continuous manner, with $\mathrm{CO}_{2}$ and nutrients being constantly fed to the ponds, while algae-containing water is removed at the other end.

The biggest advantage of these open ponds is their simplicity, resulting in low production costs and low operating costs. While this is indeed the simplest of all the growing techniques, it has some drawbacks owing to the fact that the environment in and around the pond is not completely under control. Bad weather can stunt algae growth. Contamination from strains of bacteria or 
other outside organisms often results in undesirable species taking over the desired algae growing in the pond. The water in which the algae grow also has to be kept at a certain temperature, which can be difficult to maintain. Another drawback is the uneven light intensity and distribution within the pond (Khan et al., 2009).

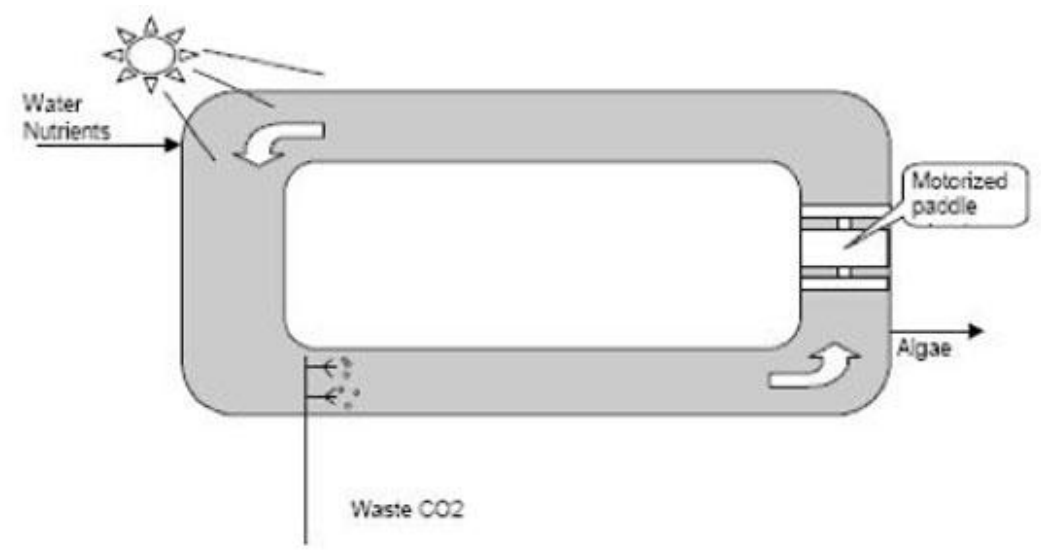

Figure 2.3 Raceway pond schematic (Benemann, 2008)

b) Closed cultivation systems

Many of the issues with an open cultivation system can be resolved by using a closed system. In a closed system, the configuration usually consists of transparent containers/tubes through which the culture medium flows and since they are transparent, light can be provided to the algae, to provide ideal growing conditions. Also $\mathrm{CO}_{2}$ can be supplied from various different sources like cement factories etc.

Photo bioreactor is defined as a closed reactor which is utilized for the inside growth of prototroph or photo-biological reactions to occur. In the contrast to open ponds, photobioreactors have better control over the growing environment leading to higher yields (Chisti, 2007). Photo-bioreactors have various reactor geometry i.e. tubular reactors can be vertical or 
horizontal and they can also be inclined. Usually flat type photo-bioreactors are preferred because of low energy consumption, high mass transfer capacity, reduction of oxygen increases, high photosynthetic efficiency compared to other bioreactors. Flat plate bioreactors have illuminated surfaces and are made out of transparent materials so it utilizes solid light with a maximum degree. Photo-bioreactors can run in a batch or continuous process. For industrial approach continuous bioreactors are preferred because it provides more control, growth rates can be maintained, in longer periods (Doucha et al., 2005).

c) Sea based cultivation system

Microalgae cultivation has been discussed in the above two headings, however algae can be grown in seawater, which is the traditional mode of growing seaweed. Due to the availability of large tracks of seawater, cultivation of seaweed for various bi-product productions could be very valuable. Seaweed should be produced in floating cultivation systems across hundreds of hectares. Most seaweed need a support to hook to; which in practice means that the cultivation system must contain a network of support mostly ropes. The amount of construction material could be drastically reduced when free-floating seaweed (like some Sargassum species) is cultivated, a structure to contain the colony would then be needed. Sea-based systems are less well developed than land based systems, although currently R\&D initiatives have been undertaken. The system for seaweed cultivation around the world like in China, Chile (a major exporter of seaweed) etc. has not changed much, hence there is scope for research and development there and options for modernization have been identified (Tseng, 2004). 


\subsubsection{Algae Based Bioenergy Products}

There are numerous fuel options that can be produced from algae. Fig 2.4 gives a brief overview along with the production technique.

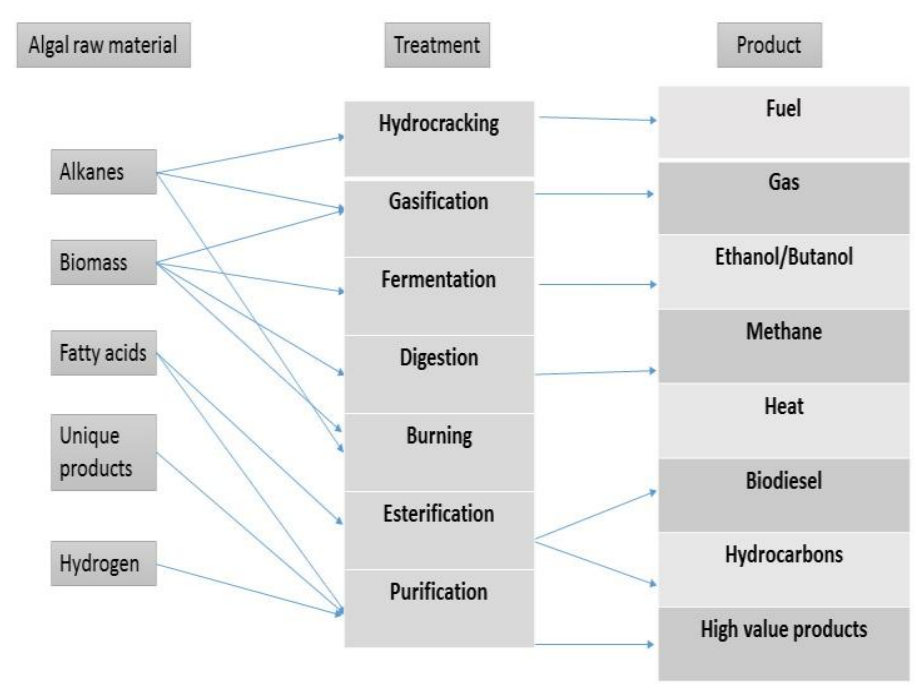

Figure 2.4 Overview of energy products from algae

The most popular of these is biodiesel produced from esterification of lipids. Algae as a source of biodiesel have gained a lot of popularity since algae can contain potentially over $80 \%$ total lipids, (while rapeseed plants, for instance, contain about 6\% lipids) (Johnson, 2009). Under normal growth conditions the lipid concentration is lower $(<40 \%)$ and high oil content is always associated with very low yields. The various lipids production can be stimulated under stress conditions, e.g. insufficient nitrogen availability. Stress conditions do enhance the lipid production but also decrease the biomass content, restricting the use for other purposes. (Food and Agriculture Organisation, United Nations, 2009). Some of the bioenergy products are explained in greater detail as follows: 
a) Hydrocarbons : Botryococcus species of algae does not produce lipids as other species do, making them unsuitable for biodiesel production, but they produce long chain hydrocarbons. These can be processed and refined in the same manner as conventional petroleum. (Banerjee et al., 2002). The disadvantage of this species is the extremely slow growth rate.

b) Ethanol: ethanol can be produced from starch containing feedstock as well as the cellulosic and hemicellulosic components of algae, present mainly in the cell wall. Algae contain low levels of cellulose and hemicellulose as compared to other feedstocks, however, they also contain very low amounts of lignin. Also algae are easier to breakdown than other cellulosic feedstocks, reducing the energy required for the process (Bush and Hall, 2006).

c) Biobutanol: cellulosic biomass and starch present in algae can also be converted to biobutanol using the Acetone-Butanol-Ethanol pathway. Recent study in this field has shown this to be a promising product produced from algae growing mostly in waste water (Ellis et al., 2012).

d) Biogas: anaerobic digestion converts organic material into biogas that contains about $60 \%$ $70 \%$ bio-methane, while the rest is mainly $\mathrm{CO}_{2}$, which can be fed back to the algae. A main advantage is that this process can use wet biomass, reducing the need for drying. Another advantage is that the nutrients contained in the digested biomass can be recovered from the liquid and solid phase (Samson and Leduy, 1982). However, the high cost of feedstock makes this not commercially viable, but using algae from wastewater can mitigate this.

e) Hydrogen: some green algae can be manipulated to photosynthetically generate $\mathrm{H}_{2}$ gas. This is done by a two-stage photosynthesis process in a closed sulfur deprived environment. The addition of ferrous hydrogenase caused anaerobiosis in the growth medium, a condition that automatically stimulated $\mathrm{H}_{2}$ production ${ }_{\mathrm{n}}$ by the algae, Chlymadomonas reinhardtii. However 
this is extremely expensive and not enough yield is shown to be considered for commercial use (Melis and Happe, 2001).

\subsubsection{Biorefinery of Algae}

Although algae possess many potential advantages, such as the ability to produce petroleum fuel substitutes without the need for fresh water or arable land (Sheehan et al., 1998; Schenk et al., 2008; Wijffels and Barbosa, 2010), profitable production has yet to be realized. This is mainly due to issues of low energy return on investment (ERoI) and huge resource requirements for large scale production facilities (Robertson et al., 2008). The ERoI of biodiesel from algae has been calculated to be around 0.22 (Beal et al., 2012). This value is very low and leads to more energy used than produced, making it a very inefficient source of energy. Thus, the low ERoI of algal fuel makes it unable to compete with other fuels (Beal et al., 2012).

Continued research and development could yield innovations to address these challenges. We propose the use of oil waste, the biomass left after extraction of oil, as feed stock for development of transportation fuel such as butanol. The biomass contains cellulose and hemicellulose and can be used by microorganisms to produce other products thus increasing the ERoI and eventually making the process economically viable (Subhadra and Edwards, 2011). This is a great use of the biomass which is normally wasted from the extraction of algal oil. The

present work studies the carbohydrate concentrations left in the algal biomass after extraction of oil and its feasibility to generate transportation fuel, especially biobutanol. 


\subsection{Pre-treatment of Cellulosic Feedstock}

The complex intertwined structure associated with the lignocellulosic biomass possesses a technological challenge in processing of lignin, cellulose and hemicellulose. The process of breaking the bonds between the lignin and other carbohydrates using chemical or thermochemical operation is called pre-treatment as illustrated in Figure 2.5. Pre-treatment is an important step to increase the bioavailability of sugar monomers from cellulosic biomass. Several pre-treatment methods like steam explosion, ammonia fibre explosion, dilute acid hydrolysis, lime treatment, carbon dioxide explosion, alkaline hydrolysis, oxidative delignification, pulsed-electric-field pre-treatment, biological pre-treatment and many others have been employed in past studies (Kumar et al., 2009).

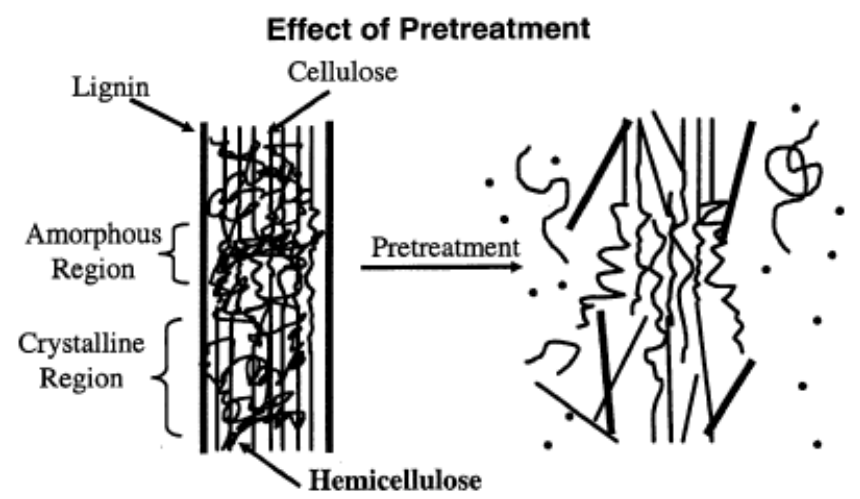

Figure 2.5 Effect of pre-treatment on lignocellulosic biomass (Zhang and Shahbazi, 2011)

If pre-treatment was not performed, the hydrolysis enzymes would face difficulty accessing the polysaccharide chains embedded within the lignin polymer. Steam pre-treatment coupled with dilute acid constitutes the best strategy to convert all hemicellulose into monosaccharides and oligosaccharides. While the wet-oxidation and alkaline methods are relatively more effective in 
solubilizing lignin, they leave behind insoluble hemicellulose in polymeric form (Bjerre et al., 1996). It is possible that during acid pre-treatment, a complex mixture of bacterial inhibitors such as furfural and hydroxymethyl furfural would be generated; however, the inhibitors could be substrate-specific (Ebener et al., 2003). Furfural is not an inhibitor to C. beijerinckii but it affects the growth of other microorganisms and the biobutanol yield (Ezeji et al., 2007). Earlier experiments in the lab determined that Furfural inhibitor production during the SSF was quantified to be in the range of 0.5 to $0.6 \mathrm{~g} / \mathrm{L}$ for all strains (Syed, 2012). These concentrations were significantly lower than the inhibitory levels of $1 \mathrm{~g} / \mathrm{L}$, above which furfural activity is known to negatively affect fermentation (Modig et al., 2002). The low concentration of furfural can be explained by the lower temperature of $120^{\circ} \mathrm{C}$ at which pre-treatment was performed and due to the use of dilute acid (Saha et al., 2005). Studies have shown that the concentration of inhibitors increases with an increase in pre-treatment temperature (Wei et al., 2012). Therefore, this study focussed on the effect of other inhibitors like butanol while neglecting the effect of insignificant concentrations of furfural.

\subsection{Consolidation of Bioprocesses}

Biomass processing schemes involving enzymatic or microbial hydrolysis commonly involve four biologically mediated transformations: the production of saccharolytic enzymes (cellulases and hemicellulases); the hydrolysis of carbohydrate components present in pretreated biomass to sugars; the fermentation of hexose sugars (glucose, mannose and galactose); and the fermentation of pentose sugars (xylose and arabinose) (Lynd, 2005). Usually, after pre-treatment, enzymatic hydrolysis is used to convert the cellulose and hemicellulose into monomeric sugars. The sugars are then fermented to solvents (ethanol, biobutanol and others) using microbes (yeast 
or bacteria). When enzymatic hydrolysis and fermentation are performed sequentially, the process is referred to as separate hydrolysis and fermentation (SHF). However, the two process steps can be performed simultaneously, i.e. simultaneous saccharification and fermentation (SSF) (Takagi et al., 1977). In a variant of the SSF process, simultaneous saccharification and co-fermentation (SSCF), the hydrolysed hemicellulose and the solid cellulose are not separated after pre-treatment, allowing the hemicellulose sugars to be converted to ethanol (EtOH) concurrently with SSF of the cellulose (McMillan et al., 1999; Teixeira et al., 1999). Kumar et $a l$,. (2005) have proposed an interesting way to integrate the feedstock transport with the ethanol production facility and the saccharification process named simultaneous transport and saccharification. The authors consider that the enzymatic hydrolysis of corn stover can be carried out in pipelines during its transport; the hydrolyzed corn stover could directly enter the ethanol fermentation plant, saving about 0.2 US cents/L EtOH. This could be a potential method and transport for biobutanol production as well. Figure 2.6 depicts a schematic of the different types of consolidated bioprocesses. The acronyms used in the figure are as follows: CF: cofermentation; SSF: simultaneous saccharification and fermentation; SSCF: simultaneous saccharification and co-fermentation; CBP: consolidated bioprocessing. Main stream components: C: cellulose; H: hemicellulose; L: lignin; Cel: cellulases; G: glucose; P: pentoses; I: inhibitors; EtOH: ethanol 


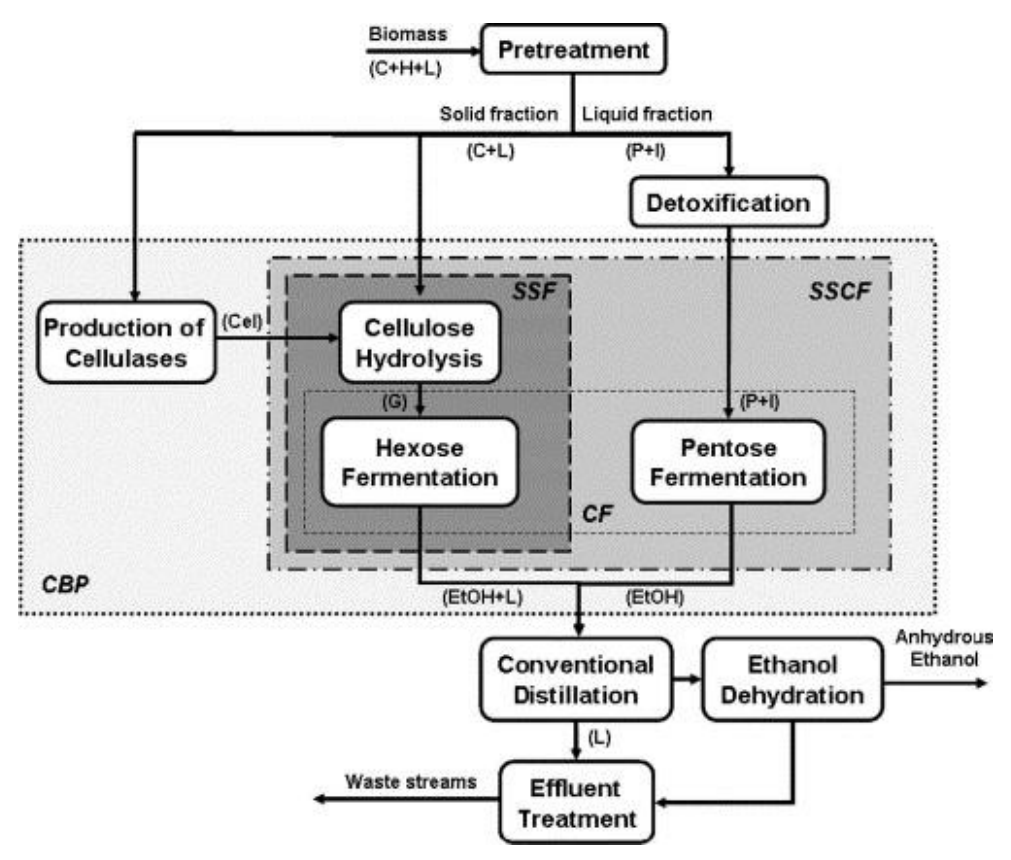

Figure 2.6 Diagram of fuel ethanol production from lignocellulosic biomass (Cardona and Sanchez, 2007)

Processes in which cellulosic biomass is fermented to desired products in one step without adding externally produced enzymes are of obvious appeal. Consolidated Bioprocessing (CBP) is widely recognized as the ultimate configuration for low cost hydrolysis and fermentation of cellulosic biomass (Olson et al., 2012). However the critical problem with CBP (SSF/ SSCF/) is the difference in temperature optima of the cellulases and the fermenting microorganism (Lynd et al., 2005).

\subsection{ABE Fermentation Process}

Several studies have shown that biobutanol can be produced from numerous microorganisms belonging to the clostridium family (Schoutens et al., 1985; Formanek et al., 1997). ABE fermentation is a two phase process involving acidogenesis (production of acids like acetic and 
butyric acid) followed by solventogenesis (production of solvents by conversion to acetone, biobutanol and ethanol) (Dürre, 1998). The enzymes produced by the strains can consume and metabolize sugars into acetone, butanol and ethanol by the ABE pathway as shown the Figure 2.7 .

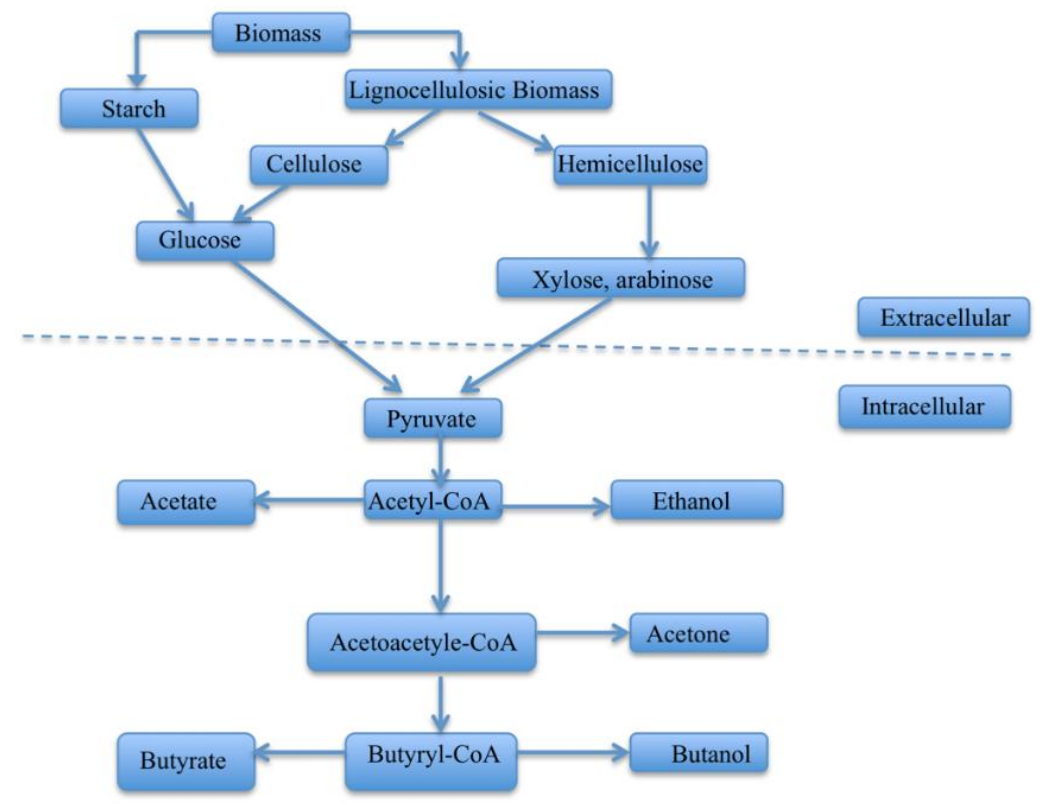

Figure 2.7 ABE Pathway (Nigam and Singh, 2011)

The process of production of the solvents is very complicated and difficult involving secretion of numerous enzymes by clostridia that facilitate the breakdown of polymeric carbohydrates into monomers of simple sugars. There are two metabolic units in the stages of organic acid formation. The first one is the unit of acetic acid formation from carbohydrate (glucose) and the second is the metabolic unit of butyric acid formation from glucose. Both processes are shown in the Figure 2.7. For the first unit, Glucose is converted to pyruvate and then to acetyl-CoA, which is converted to acetyl-P using the enzyme phosphate trans-acylase and finally to acetate (acetic acid) using the enzyme acetate kinase. The second metabolic unit of this acidogenic stage is the 
conversion of glucose to butyrate. Glucose is converted to pyruvate through glycolysis, which is then converted to acetyl-CoA. It then uses the enzyme thiolase to convert to acetoacetyl-CoA. The enzyme 3-hydroxybutyryl-CoA dehydrogenase converts acetoacetyl-CoA to 3hydroxybutyryl-CoA. Crotonase enzyme then converts the previous product to crotonyl-CoA. Butyryl-CoA dehydrogenase converts crotonyl-CoA to butyril-CoA. This product can be then converted to butyrate utilizing any of three possible pathways. These units comprise the acidogenesis sequence. The solventogenic sequence follows the same sequence as the first metabolic unit of the acidogenic sequence until the formation of acetyl-CoA. This product in the solventogenic stage is converted first to acetaldehyde using enzyme acetaldehyde dehydrogenase and is later converted to ethanol using ethanol dehydrogenase. The same acetyl-CoA is also converted to acetoacetyl-CoA using thiolase and then converted to acetoacetate and finally to acetone using enzyme acetoacetate decarboxylase. The pathway for the generation of the biobutanol is similar to the butyrate acidogenic pathway until the production of butyrl-CoA. While in the acidogenic pathway, butyril-CoA is converted to butyrate; in the solventogenic pathway the product is converted to butyraldehyde and later to biobutanol using the enzyme butyraldehyde dehydrogenase and butanol dehydrogenase respectively (Jones and Woods, 1986). To render ABE fermentation economically feasible, it is important to integrate pretreatment, hydrolysis, fermentation and recovery into a single stage (Hahn-Hägerdal et al., 2006). Furthermore, biobutanol toxicity is a major issue in $\mathrm{ABE}$ fermentation. A concentration of around $13 \mathrm{~g} / \mathrm{L}$ of $\mathrm{n}$-biobutanol is relatively toxic and will inhibit the bacterial cells from producing more solvents (Qurat-ul-Ain Syed et al., 2008). 


\subsection{Clostridial Strain Development for Biobutanol Production}

The ABE process has undergone extensive study, thus the biggest potential for optimization lies in the metabolic engineering of bacterial species, i.e clostridia (Luque et al., 2011). It is well known that cellulolytic and solventogenic (solvent producing) bacterial species such as Clostria thermocellum $(\mathrm{Ct}), \mathrm{C}$. beijerinckii $(\mathrm{Cb})$, and C. acetobutylicum $(\mathrm{Ca})$ have the potential to ferment carbohydrates into acetone, biobutanol, and ethanol (ABE) via consolidated bioprocessing, which is attractive for economic and environmental reasons (Formanek et al., 1997). Clostridia are obligate anaerobe, gram-positive, sporulating firmicutes that include both pathogenic species to humans and animals, and non-pathogenic species relevant to the commercial conversion of renewable resources into biofuels and other chemicals (Jones and Woods, 1986). Among them, Clostridium beijerinckii $(\mathrm{Cb})$ and Clostridium acetobuylicum are best-known strains for biobutanol fermentation and have the ability to produce solvents from lignocellulosic biomass via simultaneous saccharification and fermentation (SSF). During the acidogenic stage, acetic and butyric acid are produced leading to a drop in the $\mathrm{pH}$; then in the solventogenic stage, microorganisms produce acetone, biobutanol, and ethanol. After solvents start forming, the butyrate decreases to extremely small levels, and $\mathrm{CO}_{2}$ and $\mathrm{H}_{2}$ are produced as co-products of the fermentation (Ladisch and Svarczkopf, 1991).

As mentioned earlier (see section 2.6) one of the major challenges of SSF and SSCF is the different temperatures required for the enzymes to break down the cellulose and the microbes fermenting the sugars released. To overcome this hurdle, The Nanocomposites and Biomaterials lab, Ryerson University (P.I. Dr. Yaser Dahman) has done work to fuse together $C t$ with $\mathrm{Ca}$ and 
$\mathrm{Cb}$. This created fused strains where the saccharification and fermentation was done by the same strain and the strain was also efficient at handling higher temperatures that are required for breaking down of cellulose (Syed, 2012). Previous work in the Nanocomposites and Biomaterials Lab focussed on fusing $C t$ that is an anaerobic cellulolytic (breaks down cellulose to produce sugars) thermophilic bacteria that grows at higher temperatures with $C a$ and $C b$, both of which are mesophilic bacteria (grow at moderate temperatures) that are saccharolytic (breaks down sugars).

\subsubsection{Protoplast Fusion Technology}

Protoplast fusion is a genetic engineering technology that involves fusion of cells of two different varieties being fused together to create a new hybrid variety having desired characteristics of both (Kao and Michayluk, 1974). This method, initially used in plant genetic modifications, is a great way to change the genetic makeup of cells and imparting desired characteristics to a plant species for example imparting resistance to potato leaf roll disease in potato plant (Helgeson et al., 1986).

Protoplasts are cells where cell walls have been removed and the cytoplasmic membrane is the outermost layer in such cells. Protoplast can be readily isolated from bacterial cells by digestion of cell walls with the help of lysozyme in the presence of osmotic stabilizers (Gokhale et al., 1993). Chemical fusogens (fusion-inducing) like polyethylene glycol (PEG) can help induce the fusion process. However, several other complex, efficient and expensive technologies like electro-fusion have reported higher fusion frequencies than PEG induced fusion (Sarkar et al., 2007). The use of a relatively simple technique of protoplast fusion as a means to produce novel strains and new products unobtainable by conventional methods is exciting and has aroused great 
interest in breeding intra-species, inter-species and inter-genetic hybrids for improving abilities of industrial microorganisms like that of the bacillus genera (Syed, 2012).

Previous study by colleagues in the Nanocomposites and Biomaterials Lab focussed on creating fused strains with $C b$ and $C t$ and $C a$ and $C t$ strains of clostridium respectively using PEG. ABE solvent production was examined for SSF using two protoplast-fused strains of the wild clostridial species and were compared with co-culture fermentation of the corresponding species. Fused strains were further studied for their reproducible stability. The results were contrasted with co-cultures of the bacterial strains. The fused strains showed higher yields. Table 2.4 illustrates Syed's (2012) results from fusion studies comparing the two fused strains. For the present study only the fused $C b C t$ strain which showed higher butanol production has been used. $\mathrm{Ca}$ has been discussed to give a background of the fusion studies conducted previously and has no relevance to the present study.

Table 2.4 Concentration of $\mathrm{ABE}$ and acids produced using the protoplast fused strains at $4^{\circ} \mathrm{C}$ (Syed, 2012)

\begin{tabular}{|c|c|c|c|c|c|}
\hline \multirow{2}{*}{ Fused strains } & \multicolumn{3}{|c|}{ ABE (g/L) } & \multicolumn{2}{c|}{ Acids (g/L) } \\
\cline { 2 - 6 } & Acetone & Biobutanol & Ethanol & Acetic acid & Butyric acid \\
\hline$C a C t$ (fused) & 6.11 & 12.08 & 2.01 & 1.78 & 0.92 \\
\hline$C b C t$ (fused) & 6.89 & 13.81 & 2.28 & 1.75 & 0.87 \\
\hline
\end{tabular}




\subsubsection{Mutagenesis of Bacterial strains}

However, even with the fused strains showing better yield than the wild strains and having better temperature tolerance, one of the major hurdles limiting biobutanol fermentation is the toxicity of biobutanol produced by the microorganisms, which acts as a limiting condition in biobutanol production (Liu and Qureshi, 2009). Butanol toxicity to the fermenting microorganisms limits concentrations in the fermentation broth, resulting in low butanol yields and a high cost for butanol recovery from the dilute solutions. The current toxicity levels mentioned in the literature occur at $13 \mathrm{~g} / \mathrm{L}$ (Lütke-Eversloh and Bahl, 2011; Qurat-ul-Ain Syed et al., 2008). Strain improvement has been conventionally achieved through mutation and selection. Research has shown that a clostridial strain that is more resistant to biobutanol also becomes more productive at producing biobutanol (Lütke-Eversloh and Bahl, 2011; Nochur et. al., 1990). Studies have shown that mutated $C t$ shows higher yield of biobutanol. (Nochur et al., 1990). Similarly solvent tolerant mutated C. beijerinckii strains also showed higher biobutanol yield (Thomas et al., 2014). Mutagenesis of strains is an established way to identify stronger strains (Kenyon, 1983). Mutagenesis of Clostridia can be conducted using different mutagens, for example UV or chemical mutagenesis (using mutagens like Ethyl methane sulphonate). UV and Ethyl methane sulphonate (EMS) have been used with success in numerous mutagenesis studies (Bowring and Morris, 1985; Qurat-ul-Ain Syed et al., 2008; Rogers and Palosaari, 1987) and thus were chosen for the present study. The mutagenesis process involves the exposure of mutagens to cultures of bacteria at different concentrations and time periods. These cultures are then analysed for cell count in the presence of high levels of biobutanol to determine selectivity. The strains that survive in the highest concentrations of biobutanol can then be isolated from their cultures and studied further as a potentially useful strain (Bowring and Morris, 1986). 
This study focuses on mutation of the fused $C b C t$ strain produced by colleagues at The Nanocomposites and Biomaterials lab, Chemical Engineering Dept. at Ryerson University. The $\mathrm{CbCt}$ strain was chosen for further enhancement because it showed the highest biobutanol yield during SSF using WS as feedstock.

\subsubsection{Oxygen Tolerance}

Anaerobic bacteria are those that don't require oxygen for their growth. Anaerobes are of two types:

- Facultative anaerobes that are able to grow either with or without free oxygen

O Obligate anaerobes that are able to grow only in the absence of oxygen and are inhibited by the presence of oxygen.

Clostridial species used in this study belong to those bacteria that are considered obligate anaerobes where oxygen is harmful or lethal to these bacteria. Thus the whole SSF process is conducted in anaerobic conditions, which is expensive to handle. Nevertheless, it is known that they can survive with limited exposure to air, and often eliminate oxygen or reactive derivatives via $\mathrm{NAD}(\mathrm{P}) \mathrm{H}$-dependent reduction. This system does apparently contribute to survival after oxidative stress, but is insufficient to establish long-term tolerance of aerobic conditions (Hillman et al, 2008).

Different oxidative stress protein systems are found in various anaerobicanaerobic bacteria which help them survive exposure to oxygen, for example Rubrerythrin oxidative reductase (Lumppio et al., 2001; May et al., 2008), Superoxide dismutase (SOD) (Brioukhanov et al., 2002) etc. 
Previous studies showed that manipulation of the regulatory mechanism of the oxidative stress defence mechanism could trigger aerotolerance in the obligate anaerobe Clostridium acetobutylicum (Hillman et al., 2008). Deletion of a peroxide repressor (PerR)-homologous protein resulted in prolonged aerotolerance, limited growth under aerobic conditions and rapid consumption of oxygen from an aerobic environment. The mutant strain also revealed higher resistance to $\mathrm{H}_{2} \mathrm{O}_{2}$ and activities of NADH-dependent scavenging of $\mathrm{H}_{2} \mathrm{O}_{2}$ and organic peroxides in cell-free extracts increased by at least one order of magnitude. Several genes encoding the putative enzymes were up-regulated and identified as members of the clostridial PerR regulon, including the heat shock protein Hsp21, a reverse rubrerythrin that was massively produced and became the most abundant protein in the absence of PerR. This multifunctional protein is proposed to play the crucial role in the oxidative stress defence. Studies also showed that clostridium exhibits a typical adaptive response to oxidative stresses: cells treated with a sublethal dose of a stress agent can subsequently withstand higher doses of the same agent or products generating identical reactive oxygen species (Sies, 1986).

Oxidative stress is an important consideration during the life cycle and production capabilities of the clostridium strains involved in biobutanol production. Currently the $\mathrm{ABE}$ pathway is conducted in absolute anoxic conditions, leading to use of expensive machinery and chemicals to create an anaerobic environment. This is an energy and cost intensive part of the whole process. If the bacterial strains are able to function with complete efficiency in presence of air, the costly practice of maintaining anoxic conditions wouldn't be required and regular industrial fermenters can be employed. Thus studying the oxygen tolerance of the bacterial strains and improvements to the process are an important step in making biobutanol a viable commercial fuel (Kato et al., 2004). 


\section{CHAPTER THREE MATERIALS AND METHODS}

\subsection{Materials and Chemicals}

The main bacterial strain that was used in this study is a fusant of two clostridia species namely Clostridium beijerinckii (ATCC BA101) (Cb) and Clostridum thermocellum (ATCC 27405) (Ct) that were both purchased initially from American Type Culture Collections. The fused strain $C b C t$ was prepared in the Nanocomposites and Biomaterials lab at Ryerson University (P.I. Dr. Yaser Dahman) (Syed, 2012). The $C b C t$ strain showing the highest ABE concentration (see Table 2.5) was chosen for further mutagenesis and biobutanol production study. All chemicals were purchased from Sigma-Aldrich, and were used as received without any further purification. Table 1 in appendix A summarizes all chemicals that were used in the current study.

\subsection{Experimental Procedure and Method}
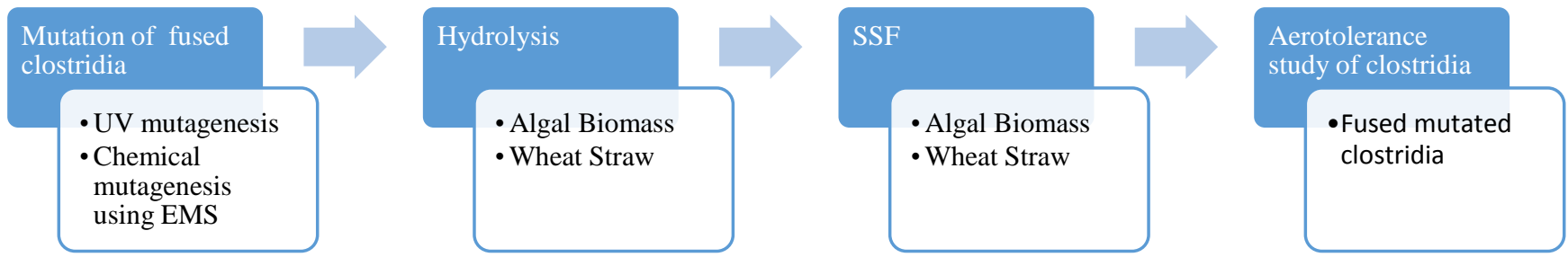

Figure 3.1 Flow chart of experimental procedure 
Figure 3.1 explains the sequential nature of the experiments conducted in this study. At first, fused clostridial strains were enhanced using mutation. The fused strains were mutated using UV radiation and chemical mutation using Ethyl methane sulphonate (EMS). Algal biomass left over after extraction of lipids was analysed for its cellulose and hemicellulose content. The algal biomass was hydrolysed using different thermal, chemical and enzymatic methods of hydrolysis. Wheat straw was hydrolysed as well. Following the hydrolysis study, SSF of the algal biomass was conducted using mutated bacterial strain. These strains were examined for their biobutanol producing capabilities during SSF of wheat straw as well. Results were compared for algal biomass with wheat straw and other cellulosic feedstocks using literature values and results generated in this study. Finally the bacterial strain was studied for its aero-tolerant capabilities.

\subsubsection{Culture Conditions and Medium Preparation}

The fused strain that was prepared earlier from the fusion of protoplast derived from $C b$ and $C t$ (i.e., $C b C t$ ) and showed the highest biobutanol concentration was selected for mutation studies (Syed, 2012). Generally, the fusion process consists of three steps; formation of protoplast, fusion and regeneration of cell wall around the fused protoplast (Bjerre et al., 1996). This protoplast-fused strain used throughout the current study is referred to as the fused parent strain.

All the mutagenesis and other microbiological practices were carried out in an anaerobic glove box (Terra Universal, Canada) under sterile conditions at a mean temperature of $25 \pm 2{ }^{\circ} \mathrm{C}$. In order to create an anaerobic environment inside the glove box (Terra Universal, Canada), a vacuum pump was used for 10 minutes to extract the air from the chamber. Then $\mathrm{N}_{2}$ gas was purged thorough the box for 10 minutes to create a sterile anaerobicanaerobic environment. The

$\mathrm{N}_{2}$ gas was stitched off after all the microbiology techniques were performed in the 
anaerobicanaerobic glove box and all the serum bottles were properly sealed using a crimper. The glove box was cleaned routinely by wiping the work surface with $70 \%$ ethanol before and after the work. In addition, the work surface was exposed to the ultraviolet light to be sterilized for 20 minutes before inoculation of the bacteria (Wedum et al., 1956).

The parent fused clostridium strain $C b C t$ was inoculated in a Clostridial Basal Medium (CBM) overnight to bring them out of their sporulation state (Qureshi and Blaschek, 2001). Prior to inoculation of the strains, their spores were heat shocked at $80^{\circ} \mathrm{C}$ for 5 minutes and then the heatshocked spore suspensions were grown overnight in a Clostridial Basal Medium (CBM) under severe anaerobic conditions (Qureshi and Blaschek, 2001). The CBM was created by mixing Glucose $10 \mathrm{~g} / \mathrm{L}, \quad \mathrm{MgSO}_{4} .7 \mathrm{H}_{2} \mathrm{O} \quad 0.2 \mathrm{~g} / \mathrm{L}, \mathrm{MnSO}_{4} .5 \mathrm{H}_{2} \mathrm{O}$ 0.01g/L, $\mathrm{FeSO}_{4} .7 \mathrm{H}_{2} \mathrm{O}, 4$ '-Para amino benzoic acid (PABA), 0.001g/L, Biotin 0.2g/L, Thiamine hydrochloride $0.001 \mathrm{~g} / \mathrm{L}$, Casein hydrolysate $4 \mathrm{~g} / \mathrm{L}$ into distilled water. After autoclaving for 20 minutes at $121^{\circ} \mathrm{C}$ sterile potassium phosphate buffer $\mathrm{pH} 7.0$ was added aseptically to a final molar concentration of 0.05 . (Bowring and Morris, 1986). The agar plates were prepared by mixing nutrient agar 23g/L of distilled water. A pour plate technique was used to create petri dishes containing nutrient agar. These plates were used to grow bacterial colonies and determine the colony count. The 2\% Ethyl methane sulphonate (EMS), a chemical mutagen, was created for chemical mutagenesis (Bowring and Morris, 1986). All media was autoclaved at $120^{\circ} \mathrm{C}$ for 60 minutes in the autoclave (Qureshi et al., 2008). The bacterial cells were incubated overnight in the CBM. A bacterial culture of $3 \mathrm{ml}$ was inoculated in $50 \mathrm{ml}$ of $\mathrm{CBM}$ media and left over night in $45{ }^{\circ} \mathrm{C}$ in a $\mathrm{CO}_{2}$ environment. After 18 hours of incubation, the bacterial culture was subjected to mutation by exposing the culture to UV radiation and EMS, a chemical mutagen. 


\subsubsection{Mutagenesis Study}

A mutagenesis study was conducted on the fused clostridium strain $C b C t$ using UV light mutagenesis and EMS chemical mutagenesis. All mutated strains were later analysed for their tolerance to biobutanol toxicity by growing them on agar plates infused with $15 \mathrm{~g} / \mathrm{L}$ and $16 \mathrm{~g} / \mathrm{L}$ of butanol. The mutated strains were then studied for their biobutanol production capabilities during SSF of WS.

\section{a. UV-Mutagenesis}

The culture medium with 18 hours of bacterial growth was placed in a flat petri dish of size 100 $\mathrm{cm}^{2}$ X $15 \mathrm{~mm}$ (i.e., surface area X depth), inside the anaerobic glove box (Terra Universal, Canada). The surface of the media was placed at a distance of $6 \mathrm{~cm}$ from the UV-light source (245 nm) (Bowring and Morris, 1986). A control sample of 100 microliters was plated on 2\% agar plates of size $100 \mathrm{~cm}^{2}$ X $15 \mathrm{~mm}$. Then the sample was placed below the UV-light tubes and exposed for time intervals of 5 minutes for a total time of 30 minutes. In order to analyse the mutated strain tolerance to biobutanol toxicity, a sample of 100 microliters was taken after each interval of 5 minutes, and were plated on nutrient agar plates in addition to agar plates containing $15 \mathrm{~g} / \mathrm{L}$ and $16 \mathrm{~g} / \mathrm{L}$ of butanol. These plates were incubated overnight and next day the cell count was determined.

\section{b. Chemical Mutagenesis}

A control sample was taken initially and plated on an agar plate. $2 \%$ EMS was added to the media and samples were taken at time limits of 20, 40, 50 and 60 minutes. Each time a sample was taken, it was washed with buffer $(25 \mathrm{mM}$ potassium phosphate with $1 \mathrm{mM}$ magnesium sulphate at $\mathrm{pH}$ 7.0) twice by centrifuging it at $2000 \mathrm{~g}$ for 5 minutes. This was done to remove the 
EMS and then the remaining cells were re-suspended in buffer and 100 microliters of the solution was plated on agar plates and $15 \mathrm{~g} / \mathrm{L}$ and $16 \mathrm{~g} / \mathrm{L}$ of butanol-infused agar plates. These were incubated and cell count was determined the next day (Bowring and Morris, 1986).

The cell count method was used to calculate the surviving fraction, which is the fraction of cells that survive exposure to the mutagen. The relative induced mutation frequency (RF) was calculated as the proportion of a mutant strain present in a cell population that had survived a recorded period of exposure to a potential mutagen, divided by the proportion of the same mutant strain that was present in the cell population not exposed to the mutagen (Bowring and Morris, 1986). The mutated strains showing the highest relative frequencies and tolerance to butanol were selected and the biobutanol production from SSF of WS was investigated. Table 3.1 depicts the strains selected for further study.

Table 3.1 Strain nomenclature for further study

\begin{tabular}{|c|c|}
\hline Strain nomenclature & Mutation parameters \\
\hline S1 & Fused parent strain \\
\hline S2 & 10 min UV \\
\hline S3 3 min UV \\
\hline S4 & 20 min EMS \\
\hline S5 & 40 min EMS \\
\hline S6 & 50 min EMS \\
\hline S7 & 60 min EMS \\
\hline
\end{tabular}

\subsubsection{Biobutanol Production in Batch SSF using WS as Feedstock}




\section{a. Hydrolysis of WS}

Prior to using it as a substrate for fermentation, WS was ground into fine particles using a $1 \mathrm{~mm}$ Sieve screen in a hammer mill (Retsch GmbH Inc., USA). Acidic pre-treated WS was obtained by suspending $4.5 \mathrm{~g}$ (dry) in $50 \mathrm{~mL}$ of $1 \%$ dilute sulphuric acid $\left(\mathrm{H}_{2} \mathrm{SO}_{4}\right)$ in $250 \mathrm{ml}$ Wheaton serum bottles (Talebnia et. al., 2010). The dilute sulphuric acid (1\%) solution was prepared by adding $1 \mathrm{ml}$ of $99.99 \%$ sulphuric acid to $99 \mathrm{ml}$ water. The WS-acid solution was autoclaved at $121^{\circ} \mathrm{C}$ for 60 minutes. The $\mathrm{pH}$ of the culture medium was adjusted to 7.0 using $\mathrm{NaOH}$ and the volume was increased to $50 \mathrm{ml}$ using autoclaved water to make up for the water lost during autoclaving process. The serum bottles were removed from the autoclave and allowed to cool down to room temperature prior to inoculation (Qureshi et al., 2008). A blank sample was taken before inoculation and analysed for initial individual and total sugars present.

\section{b. Biobutanol Production in Batch SSF}

Production of biobutanol was examined using the mutated strains showing the highest growth and relative frequency of mutation. Cells were taken from each chosen strain and incubated for 18 hours in CBM for inoculation in pre-treated WS medium. The pre-treated WS was inoculated with the mutated strains and the SSF was carried on for 120 hours. Previous studies conducted beyond 120 hours showed no change in solvent concentration after 120 hours (Liu and Qureshi., 2009), thus in the present study the SSF was carried out upto 120 hours. Samples were taken initially and then every 24 hours until 120 hours. All samples were stored at $-82^{\circ} \mathrm{C}$ in Eppendorf tubes inside an ultra-low freezer prior to being analysed. All samples were analyzed to obtain the concentration of sugars, solvents and acids, in addition to bacterial cell growth rates. These samples were quantitatively analysed using High Performance Liquid Chromatography (HPLC). 


\subsubsection{Biobutanol Production in Batch SSF using Algal Biomass}

\section{a. Hydrolysis of algal biomass}

The algae were obtained from Pond Biofuels Inc. (located in Markham, Ontario). 2grams of algae was used for each hydrolysis experiment. All hydrolysis experiments were conducted with 2 grams of algae suspended in solution with total volume of $25 \mathrm{ml}$. The dried algae were treated with different methods as follows:

1) Physical pre-treatment: The dried algae were crushed using a ball mill (Retsch GmbH Inc., USA). The final algae powder had a particle size smaller than 75 micrometers.

2) Thermal treatment: The sample was subjected to temperature of $121^{\circ} \mathrm{C}$ for 30 minutes.

3) Chemical treatment: In acidic pre-treatment the sample was subjected to $1 \%$ and $2 \% \mathrm{H}_{2} \mathrm{SO}_{4}$ (v/v). In alkaline pre-treatment the samples were treated with $1 \%$ and $2 \% \mathrm{NaOH}(\mathrm{v} / \mathrm{v})$.

4) Enzymatic treatment: The effects of a combination of xylanase, cellulase, and $\beta$-glucosidase were examined during saccharification. The samples were treated with either two enzymes (i.e., Cellulase and $\beta$-glucosidase) or all three enzymes (i.e., Xylanase, Cellulase, and $\beta$ glucosidase) to understand the effect of the combination of enzymes on breakdown of lignocellulosic material. The samples were incubated for three days when undergoing enzymatic degradation.

A combination of physical, chemical, enzymatic and thermal treatments was employed for the hydrolysis of algal biomass as detailed in Table 3.2.

Table 3.2 Hydrolysis of algae under different conditions

\begin{tabular}{|l|l|l|l|}
\hline Sample & Chemical & Thermal & Enzymatic Treatment \\
\hline
\end{tabular}




\begin{tabular}{|c|c|c|c|}
\hline & Treatment & Treatment & \\
\hline Algae1 & $1 \% \mathrm{H}_{2} \mathrm{SO}_{4}(\mathrm{v} / \mathrm{v})$ & No & No \\
\hline Algae 2 & $2 \% \mathrm{H}_{2} \mathrm{SO}_{4}(\mathrm{v} / \mathrm{v})$ & No & No \\
\hline Algae 3 & $1 \% \mathrm{H}_{2} \mathrm{SO}_{4}(\mathrm{v} / \mathrm{v})$ & $121^{\circ} \mathrm{C}$ for $30 \mathrm{~min}$ & No \\
\hline Algae 4 & $2 \% \mathrm{H}_{2} \mathrm{SO}_{4}(\mathrm{v} / \mathrm{v})$ & $121^{\circ} \mathrm{C}$ for $30 \mathrm{~min}$ & No \\
\hline Algae 5 & Water & $121^{\circ} \mathrm{C}$ for $30 \mathrm{~min}$ & No \\
\hline Algae 6 & $1 \% \mathrm{NaOH}(\mathrm{v} / \mathrm{v})$ & No & No \\
\hline Algae 7 & $2 \% \mathrm{NaOH}(\mathrm{v} / \mathrm{v})$ & No & No \\
\hline Algae 8 & Water & No & Cellulase and $\beta$-glucosidase \\
\hline Algae 9 & Water & No & Xylanase, Cellulase, and $\beta$-glucosidase \\
\hline Algae 10 & Water & $121^{\circ} \mathrm{C}$ for $30 \mathrm{~min}$ & Cellulase and $\beta$-glucosidase \\
\hline Algae 11 & Water & $121^{\circ} \mathrm{C}$ for $30 \mathrm{~min}$ & Xylanase, Cellulase, and $\beta$-glucosidase \\
\hline Algae 12 & $1 \% \mathrm{H}_{2} \mathrm{SO}_{4}(\mathrm{v} / \mathrm{v})$ & $121^{\circ} \mathrm{C}$ for $30 \mathrm{~min}$ & Cellulase and $\beta$-glucosidase \\
\hline Algae 13 & $1 \% \mathrm{H}_{2} \mathrm{SO}_{4}(\mathrm{v} / \mathrm{v})$ & $121^{\circ} \mathrm{C}$ for $30 \mathrm{~min}$ & Xylanase, Cellulase, and $\beta$-glucosidase \\
\hline
\end{tabular}

\section{b. Biobutanol production in batch SSF}

Following the hydrolysis of algal biomass, the production of biobutanol from algal biomass was studied and yield calculated. A total of 2 grams of algal biomass was used per sample in this experiment. The algal biomass was subjected to physical pre-treatment to create particles with larger surface area, thus enhancing the effects of the subsequent pre-treatments (Mosier et al., 2005). In this study the physical pre-treatment was followed by thermal, chemical and enzymatic pre-treatment methods as detailed in Table 3.3. 
Table 3.3 Different pre-treatment methods selected before SSF

\begin{tabular}{|l|l|l|l|}
\hline Sample & Chemical treatment & Thermal treatment & Enzymatic treatment \\
\hline A1 & Water & $121^{\circ} \mathrm{C}$ for $30 \mathrm{~min}$ & No \\
\hline A2 & Water $+1 \%$ Acid $(\mathrm{v} / \mathrm{v})$ & $121^{\circ} \mathrm{C}$ for $30 \mathrm{~min}$ & No \\
\hline A3 & Water $+1 \%$ Base $(\mathrm{v} / \mathrm{v})$ & $121^{\circ} \mathrm{C}$ for $30 \mathrm{~min}$ & No \\
\hline A4 & Water $+1 \%$ Acid $(\mathrm{v} / \mathrm{v})$ & $121^{\circ} \mathrm{C}$ for $30 \mathrm{~min}$ & Xylanase, Cellulase, and $\beta$-glucosidase \\
\hline
\end{tabular}

The pretreated samples were then adjusted for $\mathrm{pH}$ using an acid $\left(\mathrm{H}_{2} \mathrm{SO}_{4}\right)$ or base $(\mathrm{NaOH})$ to create a $\mathrm{pH}$ of 7.0. These samples were inoculated with the mutated clostridium strains showing the highest biobutanol yield. A sample was taken initially and then every 24 hours upto 120 hours. These samples were stored at $-82^{\circ} \mathrm{C}$ in Eppendorf tubes inside a freezer and analysed in a High Performance Liquid Chromatography (HPLC) to determine the yield of biobutanol and other solvents.

\subsubsection{Oxygen Tolerance Study}

The strain showing the highest biobutanol yield was selected to investigate the oxygen tolerance of the mutated strain. The mutated strain was grown in CBM overnight, under both anaerobicanaerobic and aerobic conditions. Samples were taken initially, then every 8 hours upto 24 hours and were plated on agar plates to analyze growth rates and cell counts. Then, the mutated strain was used to produce biobutanol from WS in batch SSF, in both aerobic and anaerobic conditions to compare the effects of oxygen on solventogenic properties. The flask exposed to air was incubated at $45{ }^{\circ} \mathrm{C}$ in a shaking incubator (Thermo Scientific, USA) while the other flask was incubated in $45{ }^{\circ} \mathrm{C}$ in a $\mathrm{CO}_{2}$ environment. Samples were taken initially and 
subsequently every 24 hours upto 120 hours. These samples were evaluated using the HPLC to determine the $\mathrm{ABE}$ and acid concentrations (Kato et al., 2004).

\subsection{Analytical Methods}

\subsubsection{High Performance Liquid Chromatography (HPLC)}

Sugar and solvent concentrations were analyzed using pre-calibrated High Performance Liquid Chromatography (HPLC) (Perkin Elmer). This instrument was equipped with an Ion Exchange column, a pump Series 200 (Perkin Elmer), Auto sampler Series 200 (Perkin Elmer) and a Refractive Index Detector (HP1047A, Hewlett Packard). Two HPLC columns were used: Shodex KC811 for measuring sugar concentrations, and Aminex HPX-87H to measure ABE solvent and acid concentrations. The samples were initially centrifuged at $15,000 \mathrm{~g}$ for $15 \mathrm{~min}$ and double filtered through $0.2 \mu \mathrm{m}$ PTFE- filters (Whatman, USA). The solvent (mobile phase, 5 $\mathrm{mM} \mathrm{H}_{2} \mathrm{SO}_{4}$ ) was filter-sterilized and autoclaved at $121^{\circ} \mathrm{C}$ for 15 minutes. Following that, solvent was degassed using vacuum filtration. A blank sample with only double distilled water was applied in the first sample vial tray of HPLC. Samples of $100 \mu \mathrm{L}$ were diluted 20 -fold with deionized water and filtered ( $0.45 \mu \mathrm{m}$-Gelman Acrodisc CR PTEF, Millipore). Total of $10 \mu \mathrm{L}$ from each diluted sample was injected into the column and circulated for $30 \mathrm{~min}$ at a flow rate of $0.6 \mathrm{~mL} / \mathrm{min}$ using filtered ( $0.2 \mu \mathrm{m}$ nylon Millipore) and degassed mobile phase of $5 \mathrm{mM} \mathrm{H}_{2} \mathrm{SO}_{4}$. The column temperature was maintained at $60^{\circ} \mathrm{C}$ using the column heater $\mathrm{CH}-30$ controlled by an Eppendorff TC 50 (Buday et al., 1990). Data were processed by the computer software (Turbochrom Navigator). It was important to fill the HPLC testing vials to a minimum headspace to reduce the loss of solvents in the vapor phase. The reliability of HPLC column, and testing parameters were confirmed by running solvent, acid, and sugar standards in triplicate. Sugar and 
solvent concentrations were quantified from calibration curves that were constructed from standard compound of known concentration and are displayed in Appendix B.

\subsubsection{Cell Count and Growth Rate Calculations}

The cell concentration in the culture was measured using a pre-calibrated UV/Vis scanning spectrophotometer. The Beer-Lambert Law, as applied to spectrophotometric turbidity studies, correlates the concentration of bacterial growth in a solution to the absorption of visible light (Dominguez et al., 2001). Light of wavelength 450 nanometer, in the visible spectrum is passed through a dilute sample of the cultured medium kept in plastic disposable cuvettes. The resulting change light intensity due to the different samples is used to determine the growth. A plot of absorbance over time tracks the bacterial growth curve.

The cell concentration in culture was also measured using the traditional Petri dish counting technique. The initial culture was diluted to a factor of $10^{5}$. A $0.1 \mathrm{ml}$ sample of culture was added to $0.9 \mathrm{ml}$ of autoclaved water, creating a dilution of factor 10 . This was repeated 5 times to create a sample diluted to a factor of $10^{5}$ of the initial culture. A sample of $0.1 \mathrm{ml}$ or 100 microliters of the final dilution was plated onto agar plates. The plates were marked with the appropriate strain name and the dilution rate. The plates were left overnight for colonies to form. Each colony represents one cell in the original sample. The numbers of colonies were counted and multiplied by the dilution rate and expressed in cells /ml. Results were compared with the ones obtained from the UV/Vis. spectrophotometer.

The cell count method was used to calculate the surviving fraction, which is the fraction of cells that survived exposure to the mutagen. The relative induced mutation frequency (RF) was calculated as the proportion of a mutant strain present in a cell population that had survived a 
recorded period of exposure to a potential mutagen, divided by the proportion of the same mutant strain that was present in the cell population not exposed to the mutagen (Bowring and Morris, 1986).

\subsection{Biomass Composition Calculation}

Since the algal biomass used in the study is a mix of micro-algae harvested from ponds, the sugar profile for the algal biomass as a result of pre-treatment and saccharification is essential in determining the cellulose and hemicellulose concentrations present in the biomass. In the present study cellulose and hemicellulose contents of algal biomass were quantified. Four samples of air dried, ground $(75 \mu \mathrm{m})$ algal biomass (2 grams each) were boiled with $10 \mathrm{~mL}$ of $72 \%$ w/w $\mathrm{H}_{2} \mathrm{SO}_{4}$ solution for 4.5 hours in order to hydrolyse the cellulose and hemicellulose. The suspension remaining after the above treatment was filtered through a crucible and the solid residue dried at $105^{\circ} \mathrm{C}$ for 24 hours and weighed (W1). The residue was then transferred to a pre-weighed dry porcelain crucible and heated at $600{ }^{\circ} \mathrm{C}$ for $5 \mathrm{~h}$. After cooling down, it was weighed (W2) and the ash content (\%) was determined. Glucose (C1) and reducing sugar (C2) concentrations were determined from HPLC data (Ververis et al., 2007). Following these measurements, the cellulose content in the starting material was calculated using the following equation (Ververis et al., 2007):

$$
\text { Cellulose content }(\% \text { by wt. })=\left(\frac{0.9}{0.96}\right) \times \mathrm{C} 1 \times\left(\frac{\mathrm{V}}{\mathrm{M}}\right) \times \alpha \times 100
$$

where 0.9 is the coefficient that results from the molecular weight ratio of the polymer and the monomer hexose. The saccharification yield was taken as $0.96, \mathrm{C} 1$ as the glucose concentration 
$(\mathrm{g} / \mathrm{L}), \mathrm{V}$ the total volume of sugar solution $(\mathrm{L}), \mathrm{M}$ the dry weight of the algal biomass sample $(\mathrm{g})$ and $\alpha$ the dilution of the sample (if any). The percentage of hemicellulose content was calculated from the following equation (Ververis et al., 2007):

$$
\text { Hemicelluloses }(\% \text { by wt. })=\left(\frac{0.88}{0.93}\right) \times(C 2-C 1) \times\left(\frac{V}{M}\right) \times \alpha \times 100 \text {, }
$$

where 0.88 is the coefficient that results from the molecular weight ratio of the polymer and the monomer pentose, 0.93 is the saccharification yield of xylane to xylose, $\mathrm{C} 2$ is the determined reducing sugars concentration $(\mathrm{g} / \mathrm{L})$ from the HPLC results, $\mathrm{C} 1$ the glucose concentration $(\mathrm{g} / \mathrm{L})$ from HPLC results, V the total volume of sugar solution (L), M the dry weight of the algal biomass sample (g) and $\alpha$ the dilution of the sample (if any) (Ververis et al., 2007).

\subsection{Error Analysis}

In order to calculate the error and ensure repeatability of the results, SSF was repeated three times for each strain and samples were collected and stored for final analyses. Tables in Appendix C, D and $\mathrm{E}$ present raw data for concentrations of total sugars and produced biobutanol. These tables also show the averages of concentrations, standard deviation and Percent Relative Standard Deviation (\%RSD) for the repeated triplicates. Equation 3.3 was used to calculate standard deviations.

$$
\sigma=\sqrt{\frac{\sum(\mathrm{X}-\overline{\mathrm{X}})^{2}}{(\mathrm{n}-1)}}
$$

Where, 
$\sigma=$ Standard deviation Error

$\overline{\mathrm{X}}=$ Sample mean value; $\mathrm{X}=$ data point $\mathrm{n}=$ sample size;

Percent Relative standard deviation (\%RSD) was calculated by taking a ratio of the standard deviation with the mean and multiplying it with 100 as illustrated in equation 3.4

$$
\operatorname{RSD}(\%)=\frac{\text { STDEVX100 }}{\overline{\mathrm{X}}}
$$

To calculate standard deviation and \%RSD, Equations 3.3 and 3.4 were used respectively. Appendix C, D and $\mathrm{E}$ list the raw data for total sugar concentrations and biobutanol concentrations determined from three SSF experiments and the error calculations. The percent error (\%RSD) for total sugar concentrations in Tables 1-7 in Appendix D is below 2\% and within acceptable range of error for all strains used in the current study. The standard deviation for biobutanol produced from WS was in the range of 0.004 to 0.03 and the percent error was in the range of $0.03 \%$ to $0.28 \%$. The $\% \mathrm{RSD}$ for total sugar concentration from algal hydrolysis in Table 1 of Appendix E and highest error was $2.1 \%$. The error percentage for biobutanol production from algal biomass range was under $2 \%$ as well and well within acceptable levels of error. 


\section{CHAPTER FOUR RESULTS AND ANALYSIS}

\subsection{Mutagenesis of Bacterial Strains and Production of Biobutanol}

The fused bacterial strain $C b C t$ was mutated using UV radiation and EMS (see Section 3.2.2). The cell count after the mutagenesis study was used to calculate surviving fractions and relative induced mutation frequency (RF) (see Section 3.3.2). Table 1 and 2 in Appendix $C$ show the raw data results from the mutagenesis study. Figure 4.1 shows cell count after chemical mutagenesis of fused clostridia strain $C b C t$ after different mutation periods, while Figure 4.2 gives the cell count of mutated strains on exposure to $15 \mathrm{~g} / \mathrm{L}$ of butanol. As shown in Figure 4.1, the cell count from the agar plates showed a gradual decrease (from $27 \times 10^{6}$ cells $/ \mathrm{ml}$ to $7 \times 10^{6}$ cells $/ \mathrm{ml}$ ), indicating cell death due to contact with EMS (Rogers and Palosaari, 1987). However, the cell count stabilises at $50 \mathrm{~min}$ indicating a decrease in cell death rates caused by DNA repair (Bowring and Morris, 1986). Furthermore Figure 4.2 shows that bacterial cell concentrations were generally lower in the presence of butanol (i.e., $2 \times 10^{5}$ cells $/ \mathrm{ml}$ to $5 \times 10^{4}$ cells $/ \mathrm{ml}$ ) indicating the toxicity effect of butanol on the bacterial strains. However, some cells showing growth in the presence of butanol exhibited tolerance. These strains were then selected for further study. The cells at $40 \mathrm{~min}$ of EMS mutation showed the highest cell count at $15 \mathrm{~g} / \mathrm{L}$ concentration of Butanol (i.e., $2.4 \times 10^{4}$ cells $/ \mathrm{ml}$ ). 


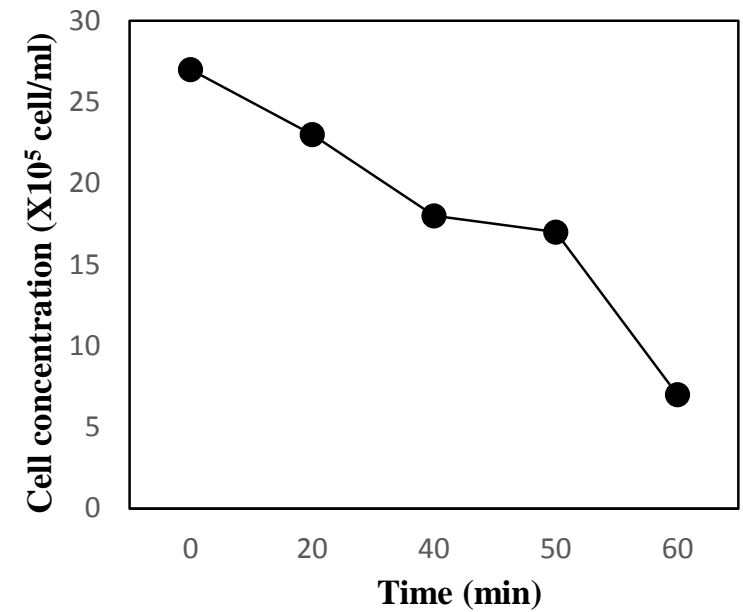

Figure 4.1 Cell count after mutagenesis with EMS

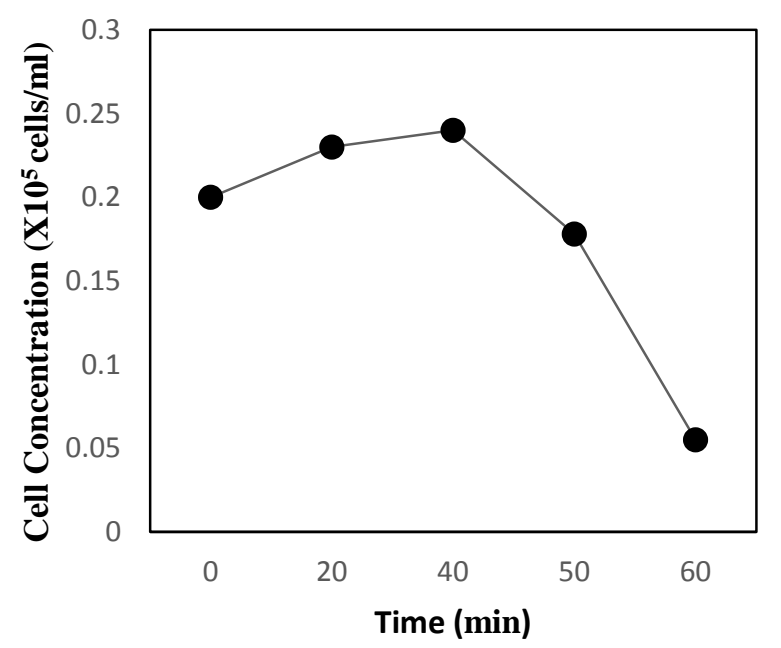

Figure 4.2 Cell count of EMS mutated cells in contact with $15 \mathrm{~g} / \mathrm{L}$ of Butanol

Figure 4.3 shows results for the surviving factor and relative frequencies calculated, and plotted for the strains mutated with EMS. For strains exposed to EMS, an initial decrease in cell count was observed, then surviving fraction value stabilised and there was no further decrease observed between the values obtained at $40 \mathrm{~min}$ and $50 \mathrm{~min}$, indicating adaptation to the mutagen. This is followed by a drastic decrease at 60 min of EMS contact indicating higher cell death and loss of viability. The relative induced mutation frequency (RF) value increased up to $40 \mathrm{~min}$ and then decreased at $50 \mathrm{~min}$ and $60 \mathrm{~min}$. This indicates an initial increase in desirable mutants that represents tolerance to butanol followed by a decrease in the butanol tolerance. This is in agreement with previous study conducted by Bowring and Morris (1986). 


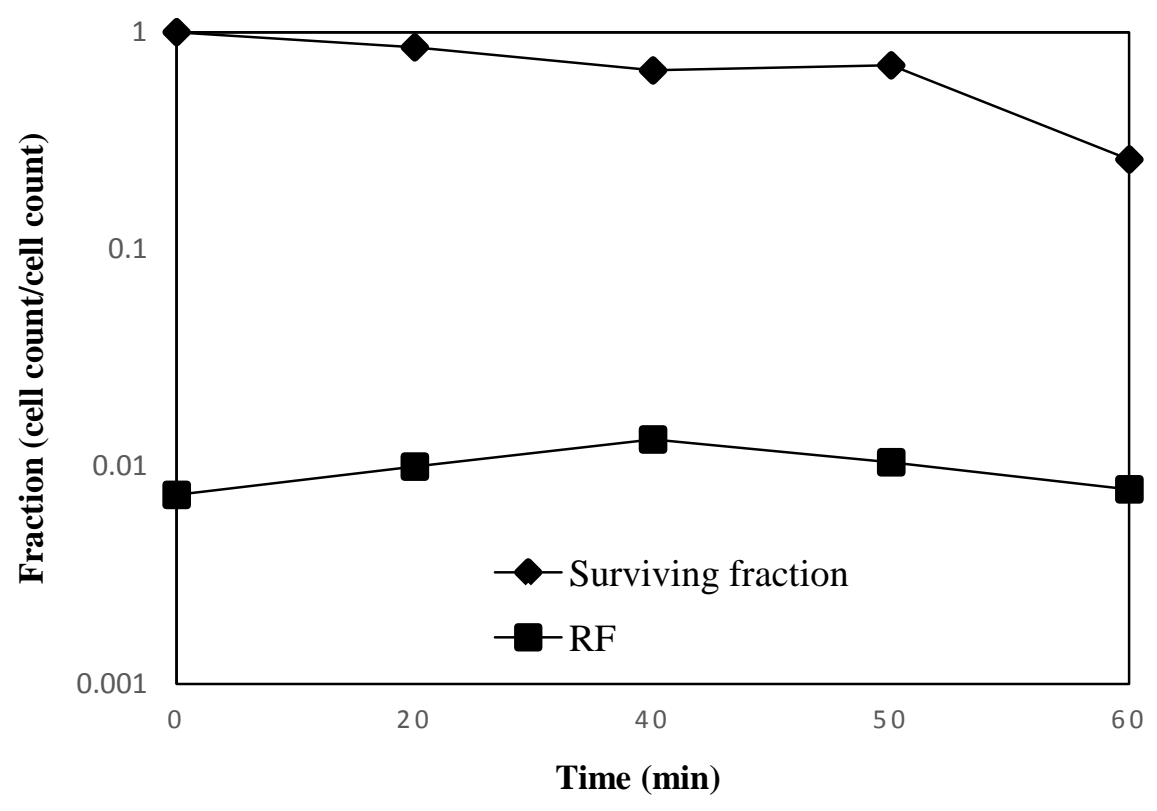

Figure 4.3 Surviving fraction and Relative frequency of induced mutation from EMS contact

Similarly, Figure 4.4 and 4.5 illustrates the cell count after UV mutagenesis. The mutated sample after exposure to UV radiation was plated on nutrient agar plates, and on $15 \mathrm{~g} / \mathrm{L}$ butanol-infused agar plates. The resulting colonies were used to determine the cell count. The strain exposed to 10 minute of UV radiation showed the most resistance to $15 \mathrm{~g} / \mathrm{L}$ of butanol as evident from the highest cell count (i.e., $1.4 \times 10^{5}$ cells/ml). The cell count decreased continuously with increase of UV exposure due to cell death as a result of prolonged UV radiation. Also, cells irradiated with longer exposure of UV failed to show any butanol tolerance, indicating a lack of vigour due to excessive damage of DNA (Ikehata and Ono, 2011). 


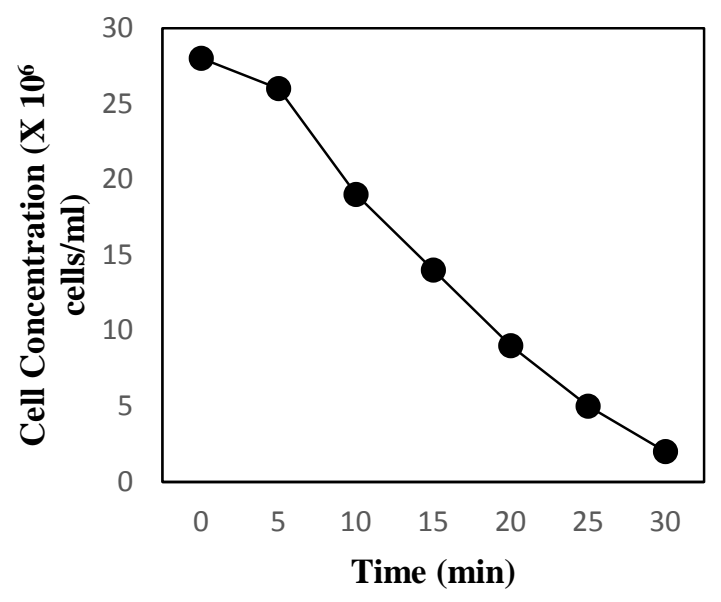

Figure 4.4 Cell count after mutagenesis with UV radiation

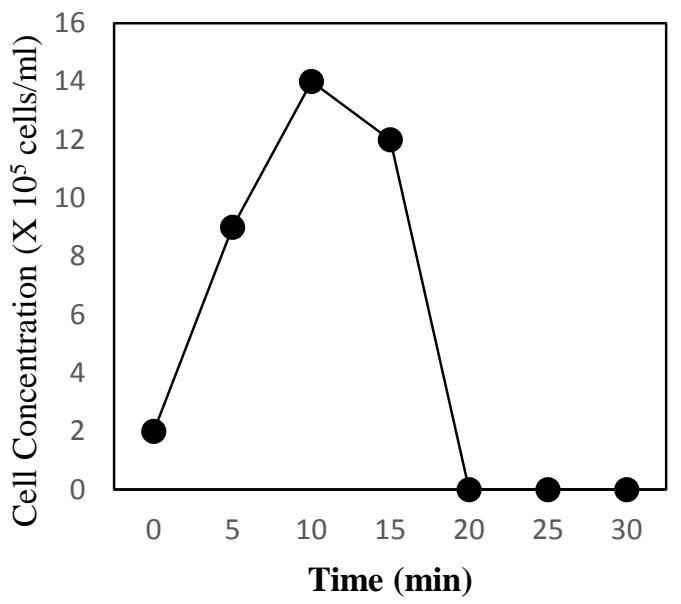

Figure 4.5 Cell count of EMS mutated cells in contact with 15g/L of Butanol

Figure 4.6 elucidates the surviving fraction and RF for cells mutated by exposure to UV radiation. The surviving factor decreased significantly with exposure to UV radiation above 15 minutes and a high relative induced mutation frequency was evident from the Figure. There was a sudden increase in RF, from fused parent strain to strain exposed to UV for 10 minutes followed by a lag as exposure time to UV increased, indicating a reduction in the rate of relative frequency of mutations induced. 


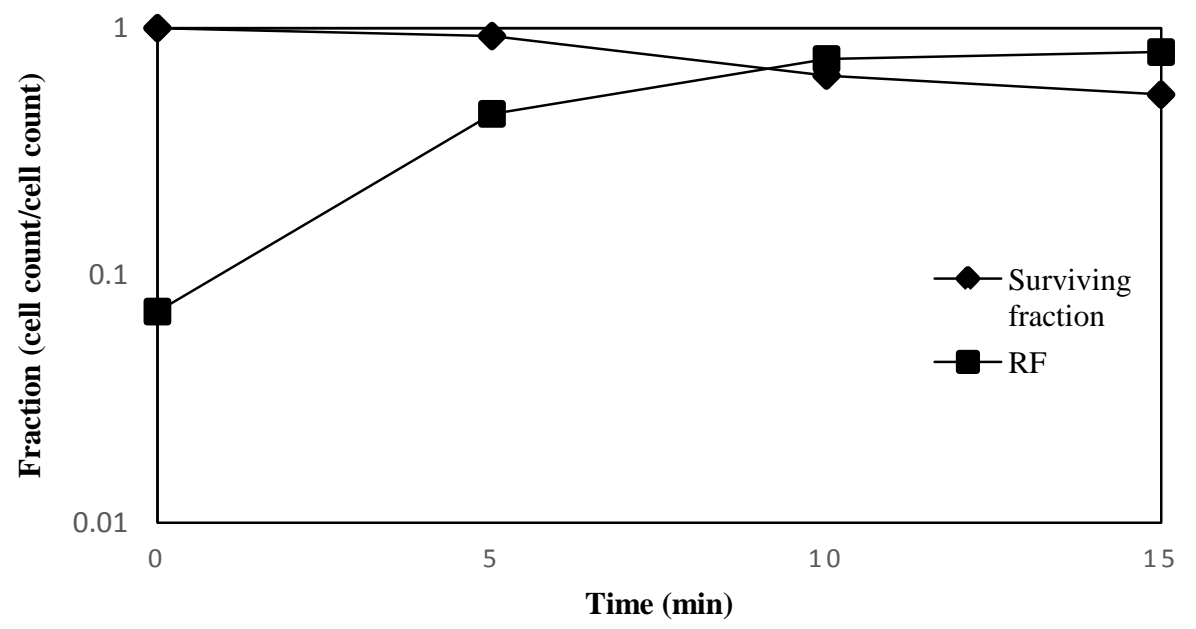

Figure 4.6 Surviving fraction and Relative frequency of induced mutation from UV exposure

The cell count trend obtained after mutation with UV and EMS indicated that the loss of cell viability was lower for prolonged (60 minutes) EMS mutation (70\% cell death) when compared with UV exposure (30 minutes) where it was significant (93\% cell death). The RF however, was much higher for UV than EMS. A similar trend was noticed in previous studies (Bowring and Morris, 1986) This was explained by the different mechanism of mutations caused by UV and EMS, where UV mutation is an indirect mutation caused by misrepair of DNA thus causing heavy DNA damage, whereas EMS causes direct point mutation without as a heavy collateral DNA damage (Ikehata and Ono, 2011). The mutated strains showing the highest relative frequencies and tolerance to butanol for both UV and EMS mutagenesis were selected and the biobutanol production from SSF of WS was investigated. SSF was conducted for a total of 120 hours.

Figure 4.7 displays individual sugars' concentration profiles obtained during butanol SSF experiments using the non-mutated $\mathrm{CbCt}$ parent strain of fused clostridia. According to Figure 
4.7, results demonstrated that the sugar concentrations increased in the first day of fermentation. This can obviously be observed for glucose, xylose, and arabinose, and while the increase in the concentration of mannose was relatively minor, while there was no increase in galactose concentration. The increase in total sugar is a result of the continuous saccharification of nonhydrolyzed polysaccharides that release monomers like glucose, xylose, mannose, galactose and arabinose by action of the enzymes released from the fused strains (Qureshi et al., 2008). It is important to note that no external enzymes were added during the SSF and all enzymes were generated after inoculation with the fused strains. Figure 4.7 shows a rise in sugar concentrations in the first 24 hours followed by a decrease upto the end of the 120 hours, where most of glucose (98\%), arabinose $(100 \%)$ and mannose $(100 \%)$ was consumed. While individual sugars concentrations rise during the first 24 hours due to the cellulolytic action of the cells, they start to drop significantly afterwards due to their consumption and metabolism into solvents and acids through the ABE process (Qureshi et al., 2007). Figure 4.7 also indicates that hemicellulotic pentose sugars such as xylose (56\%) are not completely consumed at the end of the fermentation. At $120 \mathrm{~h}$, the concentration of xylose stood at $5.76 \mathrm{~g} / \mathrm{L}$. However very small traces of glucose $(0.56 \mathrm{~g} / \mathrm{L})$ were found suggesting a nearly complete consumption of glucose. High levels of galactose $(62 \%)$ were left after the 120 hours. This has been explained in the literature by the different uptake mechanism associated with the different sugars. The transport of sugars into the cell through the cell membrane uses the phosphoenolpyruvate-dependent phosphotransferase system (PTS), which is involved in the transfer of a phosphate group from phosphoenolpyruvate (PEP) to the sugar. While glucose uptake is associated by PTS, galactose transport was supported by a non-PTS mechanism, as the phospohorylation of this sugar was supported by adenosine triphosphate and not PEP (Ezeji et al., 2007). 


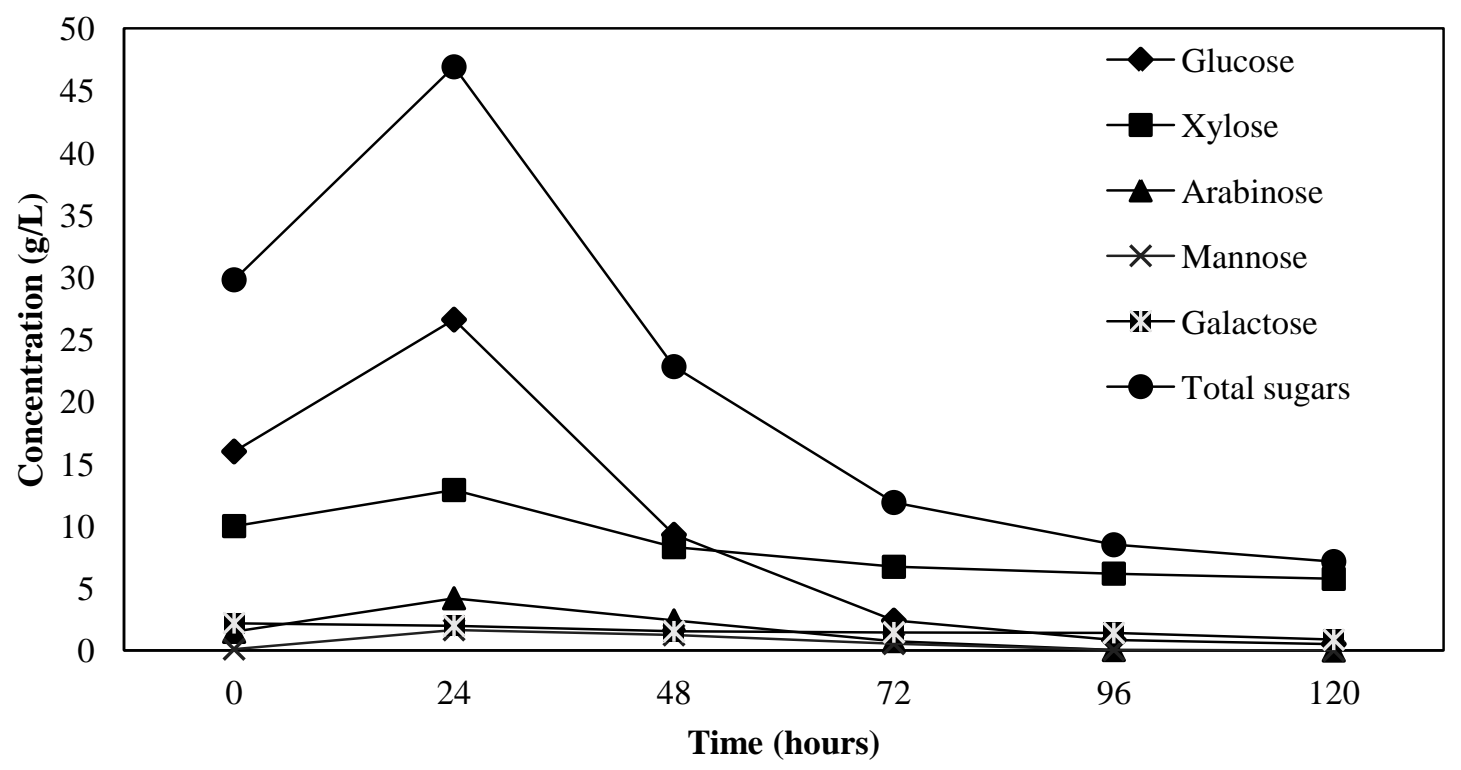

Figure 4.7 Individual sugar consumption profile of strain S1 during SSF of WS

Figure 4.8 illustrates individual sugar concentration profiles obtained with strain S2, which was exposed to UV for 10 minutes (see Table 3.1). It follows a similar pattern of sugar production as strain S1. Similarly, consumption of sugar was due to cellulolytic action of the enzymes produced by the clostridial strain until the first day of SSF (i.e., 24 hours). This was followed by sugar consumption and metabolism to biobutanol and other solvents and acid though the $\mathrm{ABE}$ fermentation process. 


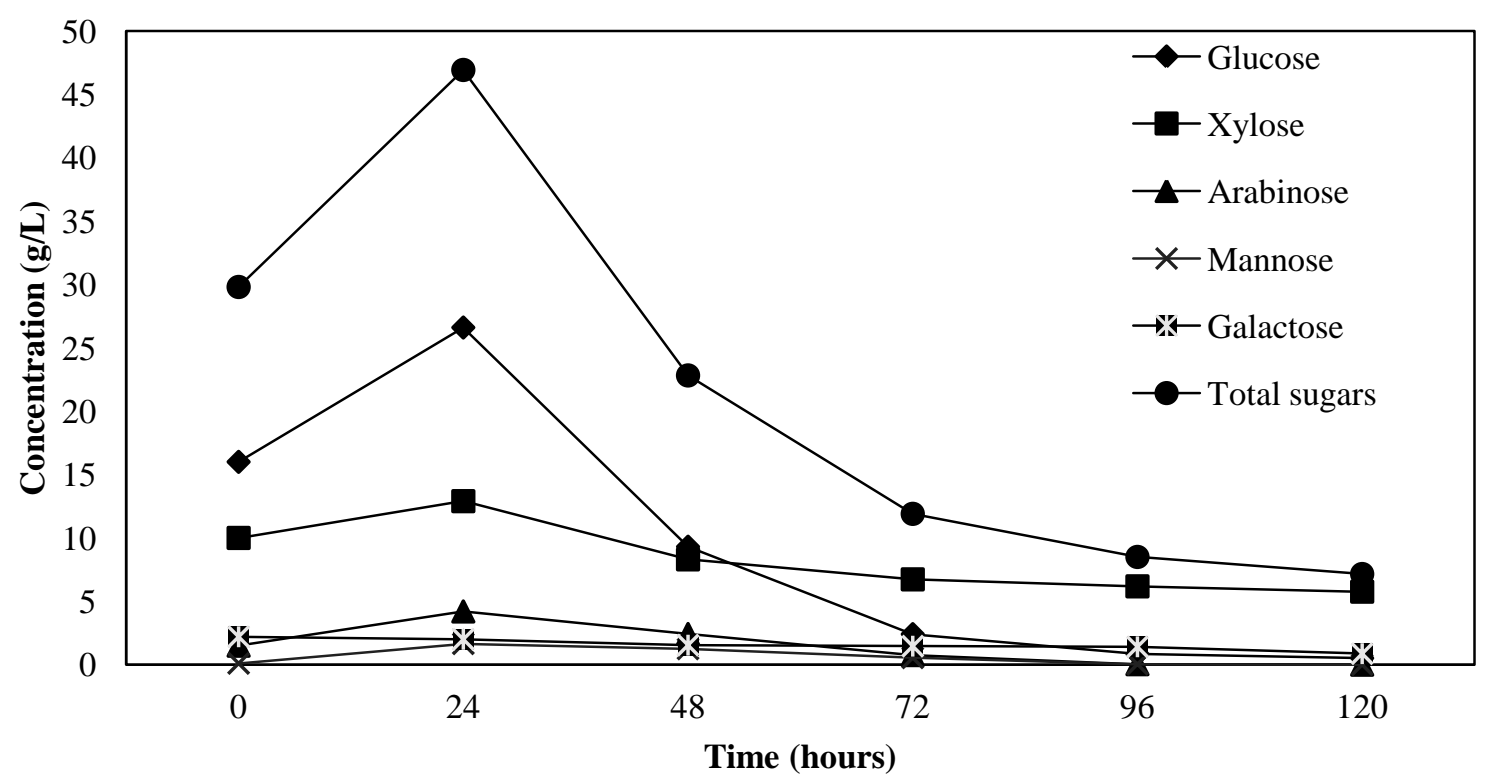

Figure 4.8 Sugar concentration profile by strain S2 during SSF of WS

Figures 4.7 to 4.13 also shows individual sugar consumption patterns during SSF of WS. It is clear that all profiles followed similar patterns for all mutated strains. Strains S2, S4 and S5 showed higher sugar production and consumption compared to all other and were the best performing of all mutated strains in terms of sugar produced and consumed. It is also interesting to note that the hemi-cellulosic pentose sugars such as xylose were not completely consumed at the end of the fermentation, whereas Mannose and Arabinose were completely consumed. The sugar consumption data for all the strains is displayed in Table 3 to 9 in Appendix C. 


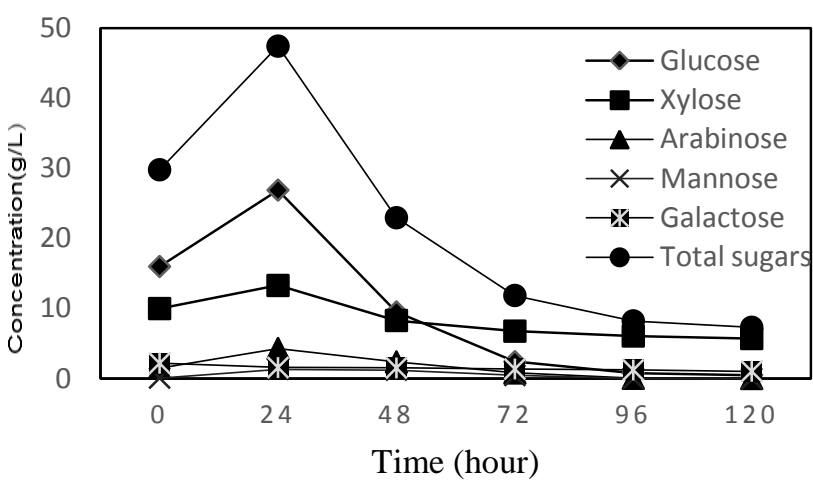

Figure 4.9 Sugar concentration profile by strain S3 during SSF of WS

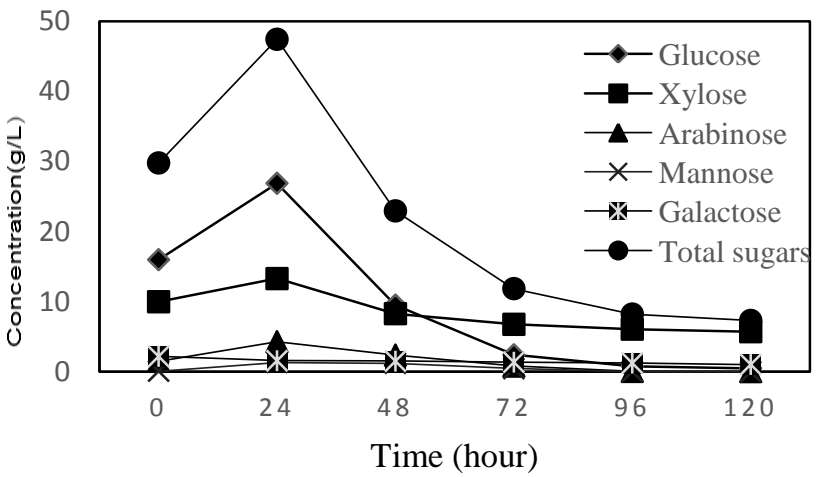

Figure 4.11 Sugar concentration profile by strain S5 during SSF of WS

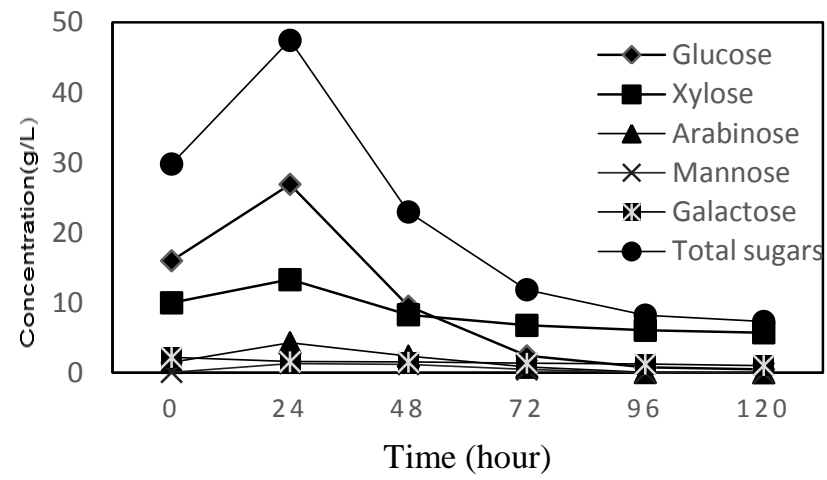

Figure 4.13 Sugar concentration profile by strain S7 during SSF of WS

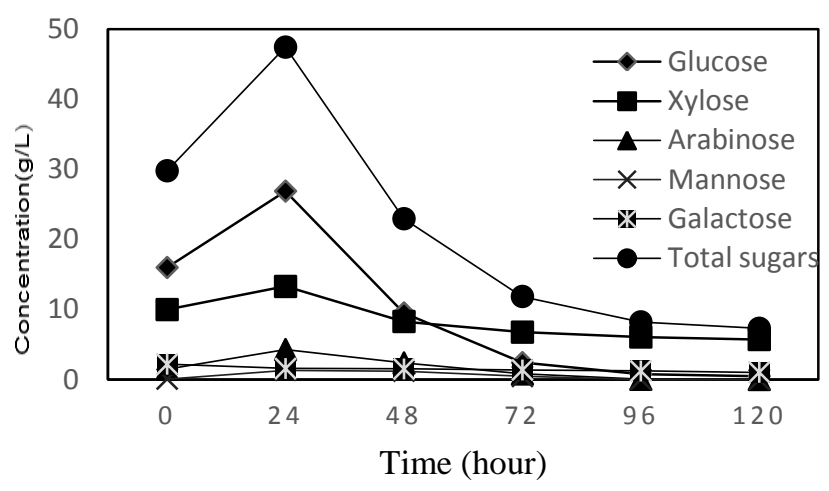

Figure 4.10 Sugar concentration profile by strain S4 during SSF of WS

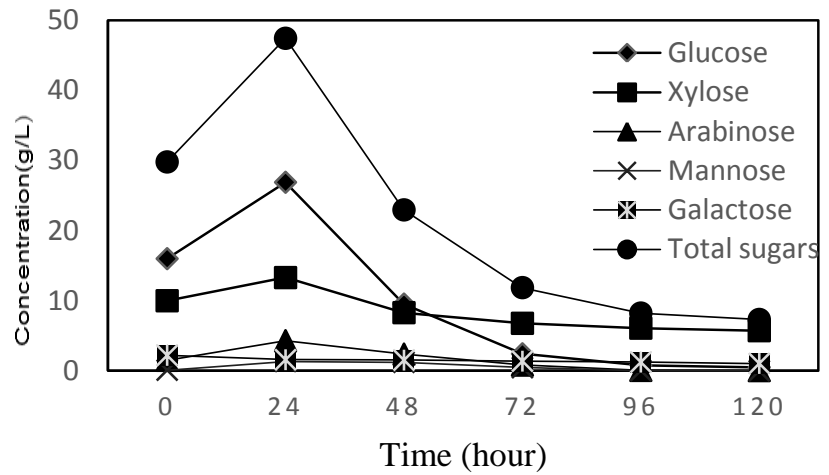

Figure 4.12 Sugar concentration profile by strain S6 during SSF of WS 
Table 4.1 lists initial and final individual and total sugar concentrations during SSF of WS. In the current study, it was found that total sugars produced during the hydrolysis of WS were around $45 \mathrm{~g} / \mathrm{L}$. This value is almost equivalent to the total sugars concentration reported from previous studies (i.e., range of 40-45 g/L by Qureshi et al. (2007). Examining Table 4.1 reveals that the highest total sugar consumption was observed with strain S2 (i.e., consumption of $41.26 \mathrm{~g} / \mathrm{L}$ ). S2 was closely followed by strains S5 (i.e., $40.11 \mathrm{~g} / \mathrm{L}$ ). A total of $85.4 \%$ of sugar conversion was noticed with strain S2 that was the highest value, amongst all the strains mutated by either UV or EMS. The highest glucose consumption was exhibited by strain S2 (i.e., 26.6 g/L). Glucose, arabinose, mannose were consumed near to completion, however larger amounts of xylose and some galactose were left at the end of 120 hours. In previous studies, it was found that in either batch or fed-batch cultures xylose utilization was inhibited at higher glucose concentrations. This was attributed to glucose mediated catabolic repression (Fond et al., 1986; El Kanouni et al., 1998; Ounine et al., 1985; Xiao et al., 2011). This is evident also in Figures 4.7 to 4.13 as well. It was noticed that the presence of higher concentrations of glucose (above $15 \mathrm{~g} / \mathrm{L}$ ) inhibited utilization of xylose leading to invariably higher percentages of xylose left during the SSF time period, as well as galactose whereas glucose, arabinose and mannose were completely utilized. The values of total sugar consumed by all strains examined in this study can be found in Table 10 in Appendix $\mathrm{C}$ along with the values of percentage sugar conversion. Percentage sugar consumption is calculated as the value of sugar consumed for conversion to solvents and acids through the ABE process, divided by the highest value of sugar present in the solution. Strain S2 had the highest percentage of sugar utilisation at $85.4 \%$. 
Table 4.1 Individual sugar concentrations produced by mutated strains during SSF of WS

\begin{tabular}{|c|c|c|c|c|c|c|c|c|c|c|c|c|}
\hline Strain & \multicolumn{2}{|c|}{ Glucose } & \multicolumn{2}{|c|}{ Xylose } & \multicolumn{2}{|c|}{ Arabinose } & \multicolumn{2}{|c|}{ Mannose } & \multicolumn{2}{|c|}{ Galactose } & \multicolumn{2}{|c|}{ Total Sugar } \\
\hline & $\begin{array}{c}\text { Initial }^{[\mathrm{a}]} \\
(\mathrm{g} / \mathrm{L})\end{array}$ & $\begin{array}{l}\text { Final } \\
(\mathrm{g} / \mathrm{L})\end{array}$ & $\begin{array}{l}\text { Initial } \\
(\mathrm{g} / \mathrm{L})\end{array}$ & $\begin{array}{l}\text { Total } \\
(\mathrm{g} / \mathrm{L})\end{array}$ & $\begin{array}{l}\text { Initial } \\
(\mathrm{g} / \mathrm{L})\end{array}$ & $\begin{array}{l}\text { Final } \\
(\mathrm{g} / \mathrm{L})\end{array}$ & $\begin{array}{l}\text { Initial } \\
(\mathrm{g} / \mathrm{L})\end{array}$ & $\begin{array}{l}\text { Final } \\
(\mathrm{g} / \mathrm{L})\end{array}$ & $\begin{array}{l}\text { Initial } \\
(\mathrm{g} / \mathrm{L})\end{array}$ & $\begin{array}{l}\text { Final } \\
(\mathrm{g} / \mathrm{L})\end{array}$ & $\begin{array}{l}\text { Initial } \\
(\mathrm{g} / \mathrm{L})\end{array}$ & $\begin{array}{l}\text { Final } \\
(\mathrm{g} / \mathrm{L})\end{array}$ \\
\hline S1 & 16 & 0.52 & 10 & 5.76 & 1.5 & 0 & 1.65 & 0 & 2.2 & 0.87 & 31.35 & 7.15 \\
\hline $\mathrm{S} 2$ & 16 & 0.5 & 10 & 5.71 & 1.5 & 0 & 1.65 & 0 & 2.2 & 0.88 & 31.35 & 7.11 \\
\hline S3 & 16 & 0.6 & 10 & 5.74 & 1.5 & 0.01 & 1.65 & 0 & 2.2 & 0.89 & 31.35 & 7.14 \\
\hline S4 & 16 & 0.56 & 10 & 5.74 & 1.5 & 0.02 & 1.65 & 0 & 2.2 & 1.02 & 31.35 & 7.3 \\
\hline S5 & 16 & 0.52 & 10 & 5.73 & 1.5 & 0.03 & 1.65 & 0.01 & 2.2 & 1.05 & 31.35 & 7.33 \\
\hline S6 & 16 & 0.51 & 10 & 5.77 & 1.5 & 0.01 & 1.65 & 0.01 & 2.2 & 0.9 & 31.35 & 7.15 \\
\hline S7 & 16 & 0.53 & 10 & 5.91 & 1.5 & 0.02 & 1.65 & 0.01 & 2.2 & 1.04 & 31.35 & 7.51 \\
\hline
\end{tabular}


Bacterial cell concentration for both parent $\mathrm{CbC} t$ and mutated strains were evaluated during SSF. Figure 4.14 displays the changes in cell concentration for the mutated strains over 120 hours of SSF. During the first few hours all bacteria experienced a lag phase. In this phase the cell concentration remained approximately constant because strains were adjusting themselves to the medium, temperature, and $\mathrm{pH}$ levels. After this phase, a sharp increase in cell concentration was seen, where the cells grew rapidly by feeding on the nutrients present in the culture medium. After the initial sugars present in the culture were utilised, we can see another decrease in the cell growth rate. In this phase the cells started breaking down the cellulosic biomass available to form sugar monomers, which were then utilized to produce solvents and acids. The acids are produced first (see Section 2.7), leading to a reduction in $\mathrm{pH}$, which in turn affects the growth rate. Once the strains adjusted to the new levels of $\mathrm{pH}$ they show an increase in growth again. This effect has been documented in previous studies and attributed to an injury - recovery process exhibited by clostridium strains (Baronofsky et al., 1984; Shoemaker and Pierson, 1976). The growth rate increased following this period and stays stationary till $96 \mathrm{~h}$. During the whole log phase (24h 96h) strains showed an average increase in cell concentration 500\% of the initial value. This phase ended after $96 \mathrm{~h}$ when the cell concentration decreased slowly by entering the decay phase. This phase corresponds to the solventogenic phase in the SSF process, where sugar levels are minimal and biobutanol toxicity is increasing, thus inhibiting the cell growth.

As described before, the mutated fused strains are capable of tolerating higher biobutanol concentrations. This was clearly seen until $96 \mathrm{~h}$ when there was no decline in cell concentration. Moreover, the strains exhibited a wider stationary phase until $96 \mathrm{~h}$, in which the biobutanol concentration kept increasing. This was followed by a decay phase at $96 \mathrm{~h}$, when the sugars were mostly consumed and the cell concentration decreased slowly due to rising biobutanol toxicity. 
Strain S7 differed from this pattern showing a prolonged phase, from 0 to $96 \mathrm{~h}$, followed by a lag upto 120 hours.

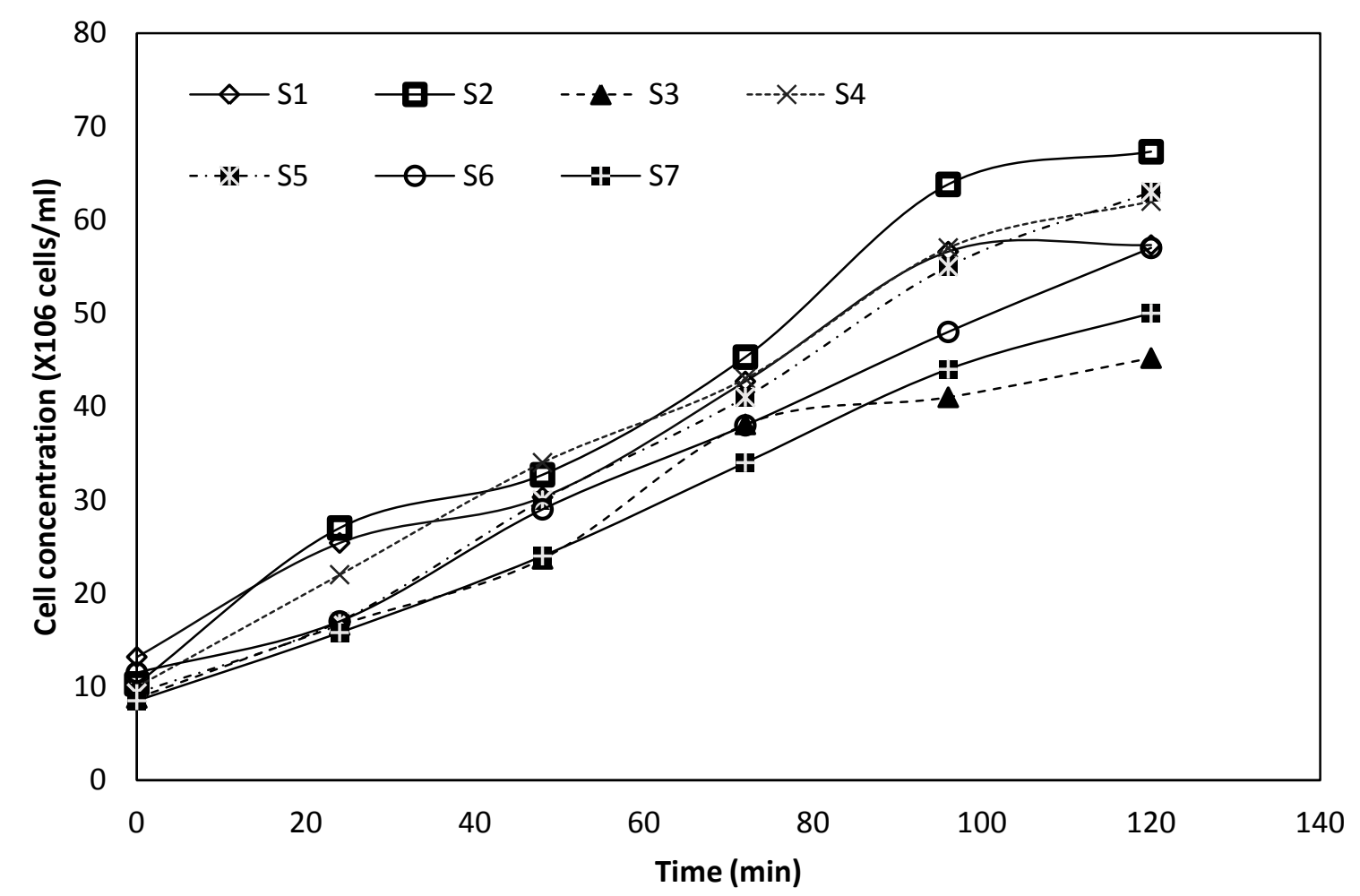

Figure 4.14 Cell concentrations of different strains over 120 hours of SSF

The growth rates for the different bacterial species were calculated. Strain S5 showed the highest overall growth rate $\left(5.3 \times 10^{5}\right.$ cell/ml.hr $)$. The highest growth rate was in the log phase in the first 96 hours for strains. The highest growth rate for the log phase wass shown by strain $\mathrm{S} 2\left(5.5 \times 10^{5}\right.$ cells $/ \mathrm{ml} . \mathrm{h}$ ) and the average cell growth rate for the log phase was $3 \times 10^{5}$ cells $/ \mathrm{ml} . \mathrm{h}$. The average cell growth rate for the acidogenic phase from was $2.3 \times 10^{5}$ cells $/ \mathrm{ml} . \mathrm{h}$. The average cell growth rate for the lag phase showed after 96 hours was $1.72 \times 10^{5}$ cells $/ \mathrm{ml} . \mathrm{h}$ 
Table 4.2 shows the final ABE produced concentration, as well as the acid production obtained for both the non mutated parent strain and mutated strains (Strain S1 to S7) from SSF of WS. As presented in Table 4.2, the highest ABE solvents and acids production was achieved by strain S2, which was exposed to UV radiation for a duration of 10 minutes. The strain was able to produce $24.8 \mathrm{~g} / \mathrm{L}$ of total $\mathrm{ABE}$ and $14.8 \mathrm{~g} / \mathrm{L}$ of biobutanol at $45^{\circ} \mathrm{C}$. According to the previous study done by Parekh et al., (1999), using the wild $\mathrm{C} b$ strain (BA101) produced lower amounts of ABE solvents (i.e., $24 \mathrm{~g} / \mathrm{L}$ ) at a pilot plant scale using a corn steep water medium, not a cellulosic feedstock. In the current study, strains S4 and S5 (chemically mutated by exposure to EMS) showed similar levels of butanol concentration to strain S2 (mutated by UV radiation) at $14.7 \mathrm{~g} / \mathrm{L}$ and $14.6 \mathrm{~g} / \mathrm{L}$ respectively.

Table 4.2 ABE and acid concentrations produced by mutated strains during SSF of WS

\begin{tabular}{|l|l|l|l|l|l|c|}
\hline Strain & Acetone & Butanol & Ethanol & Acetic & Butyric & Total \\
& $(\mathbf{g} / \mathbf{L})$ & $(\mathbf{g} / \mathbf{L})$ & $(\mathbf{g} / \mathbf{L})$ & Acid & Acid & ABE \\
$(\mathbf{g} / \mathbf{L})$ & & & $(\mathbf{L})$ & $(\mathbf{g} / \mathbf{L})$ \\
\hline S1 & 6.8 & 13.6 & 2.3 & 1.8 & 0.8 & 22.7 \\
\hline S2 & 7.2 & 14.8 & 2.8 & 1.9 & 1 & 24.8 \\
\hline S3 & 6.8 & 14.2 & 2.6 & 1.7 & 0.9 & 23.6 \\
\hline S4 & 6.8 & 14.7 & 2.4 & 1.7 & 0.9 & 23.9 \\
\hline S5 & 6.9 & 14.5 & 2.5 & 1.8 & 0.9 & 23.9 \\
\hline S6 & 6.9 & 14.2 & 2.4 & 1.8 & 0.9 & \\
\hline S7 & 6.4 & 13.2 & 2.4 & 1.8 & 0.9 & \\
\hline
\end{tabular}


Acetone and ethanol toxicity are not as great of a concern when compared to butanol due to the higher concentrations required. Cell growth inhibition was previously observed by other researchers for acetone at $70 \mathrm{~g} / \mathrm{L}$ and for ethanol at $50 \mathrm{~g} / \mathrm{L}$ to $60 \mathrm{~g} / \mathrm{L}$ (Cost and Moreira, 1983; Leung and Wang, 1981). In the current study, ethanol and acetone concentrations do not reach above $10 \mathrm{~g} / \mathrm{L}$ and therefore do not contribute to solvent toxicity and cell inhibition. However, in the case of butanol, it can be concluded that the mutation of fused strains has been able to create robust strains exhibiting higher tolerance to butanol toxicity and a higher butanol production capability.

The butanol concentration that was achieved by strain S2 is higher than previous studies (Qureshi et al., 2007; biobutanol production was examined from wheat straw using clostridium strains with an initial sugar concentration of $62 \mathrm{~g} / \mathrm{L}$ ). Several processes were examined in Qureshi's study including two that utilize SSF at $35^{\circ} \mathrm{C}$. However, one particular process that employed SSF coupled with gas stripping to remove biobutanol from the batch system recorded the highest biobutanol production of $12.7 \mathrm{~g} / \mathrm{L}$. although this value is lower than the one obtained with S2, gas stripping is essential to reduce the effect of toxicity by accumulated biobutanol and thus expected to improve the productivity of the bacterial strains. The higher values achieved in the present study are without gas stripping and show higher tolerance of the mutated novel fused strains to butanol toxicity. This demonstrates a significant potential to enhance production of biofuel by utilizing the enhanced mutated strains at industrial scale.

Table 4.3 shows the analysis of the ABE yield developed through the mutagenesis study and compares it to the data generated by the $\mathrm{C} b \mathrm{C} t$ strain data collected during previous studies. The total ABE yield was calculated for total production with respect to total sugar consumption; it 
was determined by dividing the final total $\mathrm{ABE}$ as well as acetone, biobutanol and ethanol concentrations with total sugars consumed in $120 \mathrm{~h}$ of fermentation. Strain S2 shows the highest sugar consumption and ABE yields during the SSF experiment with WS as a feedstock. According to Table 4.3, the total solvent yield was for strain S2 (UV mutated) was $0.59 \mathrm{~g} / \mathrm{g}$, with an acetone yield of $0.17 \mathrm{~g} / \mathrm{g}$, a biobutanol yield of $0.36 \mathrm{~g} / \mathrm{g}$, and an ethanol yield of about 0.06 g/g. Strains S5 and S6, (chemically mutated using EMS) showed comparable biobutanol yield values at 0.36 and 0.35 respectively and total solvent yield of $0.59 \mathrm{~g} / \mathrm{g}$ each.

Furthermore, the total ABE yield obtained from mutated strain S2 was almost 6\% higher than the $\mathrm{ABE}$ yield obtained by colleagues with a fused $C b C t$ strain. It exceeds the results observed in the literature where the total $\mathrm{ABE}$ yield of $0.49 \mathrm{~g} / \mathrm{g}$ has been reported (Qureshi et al., 2007). However, it should be mentioned that in the literature reported gas stripping method and bioreactor were used to increase the solvent production. Table 9 in Appendix C lists the yields of all solvents and acids from SSF of WS.

Table 4.3 illustrates that the mutated bacterial strains show improvement over the fused strains. There is a $6 \%$ increase in total $\mathrm{ABE}$ production. This is due to the biobutanol tolerance of the strains that has increased to $15 \mathrm{~g} / \mathrm{L}$. This is a significant increase over literature value of $13 \mathrm{~g} / \mathrm{L}$ (Qurat-ul-Ain Syed et al., 2008). Strain S7 shows a general lack of vigour that can be attributed to mutation damage due to long contact with the mutagen (Friedberg et al., 1995). 
Table 4.3 Comparison of sugar consumption and ABE yield for all strains during SSF of WS

\begin{tabular}{|c|c|c|c|c|c|c|}
\hline \multirow{2}{*}{ Strain } & \multicolumn{2}{|c|}{ Total Sugar Consumed } & \multicolumn{3}{|c|}{ ABE Yield } & \multirow{2}{*}{$\begin{array}{l}\text { Total } \\
\text { ABE } \\
\text { yield }\end{array}$} \\
\hline & $\begin{array}{l}\text { Concentration } \\
\qquad(\mathrm{g} / \mathrm{L})\end{array}$ & Percentage & $\begin{array}{c}\text { Acetone } \\
\text { yield }\end{array}$ & $\begin{array}{c}\text { Butanol } \\
\text { yield }\end{array}$ & $\begin{array}{l}\text { Ethanol } \\
\text { yield }\end{array}$ & \\
\hline $\mathrm{C} b \mathrm{C} t$ & 39.3 & 84.75 & 0.15 & 0.33 & 0.06 & 0.54 \\
\hline S1 & 39.77 & 84.76 & 0.15 & 0.33 & 0.05 & 0.55 \\
\hline S2 & 41.26 & 85.4 & 0.17 & 0.36 & 0.06 & 0.59 \\
\hline S3 & 39.88 & 84.82 & 0.17 & 0.34 & 0.06 & 0.57 \\
\hline S4 & 39.53 & 84.4 & 0.17 & 0.35 & 0.06 & 0.58 \\
\hline S5 & 40.11 & 84.54 & 0.17 & 0.35 & 0.06 & 0.58 \\
\hline S6 & 39.77 & 84.7 & 0.17 & 0.34 & 0.06 & 0.56 \\
\hline S7 & 38.47 & 84.6 & 0.17 & 0.32 & 0.06 & 0.53 \\
\hline
\end{tabular}

\subsection{Algal Hydrolysis and Biobutanol Production Studies}

Table 4.4 lists the individual and total sugar concentrations produced from algal biomass subjected to different methods of chemical, thermal and enzymatic hydrolysis (13 different pretreatment methods were used). The pre-treatment using enzymatic hydrolysis of the algal biomass in the presence of enzymes showed the highest glucose concentrations at $12.48 \mathrm{~g} / \mathrm{L}$ and $12.16 \mathrm{~g} / \mathrm{L}$. 
Table 4.4 Sugar concentrations for different pre-treatment conditions from Algal hydrolysate

\begin{tabular}{|l|l|l|l|l|l|l|}
\hline Sample & $\begin{array}{l}\text { Glucose } \\
(\mathbf{g} / \mathbf{L})\end{array}$ & $\begin{array}{l}\text { Xylose } \\
(\mathrm{g} / \mathbf{L})\end{array}$ & $\begin{array}{l}\text { Galactose } \\
(\mathrm{g} / \mathbf{L})\end{array}$ & $\begin{array}{l}\text { Mannose } \\
(\mathrm{g} / \mathbf{L})\end{array}$ & $\begin{array}{l}\text { Arabinose } \\
(\mathrm{g} / \mathbf{L})\end{array}$ & $\begin{array}{l}\text { Total } \\
(\mathrm{g} / \mathbf{L})\end{array}$ \\
\hline Algae1 & 8.64 & 5.6 & 1.84 & 4.08 & 2.4 & 22.56 \\
\hline Algae 2 & 8.16 & 5.92 & 1.68 & 4.84 & 2.48 & 22.08 \\
\hline Algae 3 & 8.88 & 5.68 & 1.68 & 4.76 & 2.8 & 22.8 \\
\hline Algae 4 & 9.36 & 5.76 & 1.68 & 4.76 & 2.72 & 24.28 \\
\hline Algae 5 & 7.12 & 5.68 & 1.6 & 4.68 & 2.96 & 21.04 \\
\hline Algae 6 & 8.24 & 6 & 1.68 & 4.6 & 2.64 & 22.16 \\
\hline Algae 7 & 8 & 6.08 & 1.76 & 4.6 & 2.48 & 21.92 \\
\hline Algae 8 & 12.48 & 6.56 & 1.6 & 4.68 & 2.08 & 26.4 \\
\hline Algae 9 & 12.16 & 6.4 & 1.84 & 4.52 & 2.16 & 26.08 \\
\hline Algae 10 & 10 & 6.24 & 1.84 & 4.92 & 2.32 & 24.32 \\
\hline Algae 11 & 10.16 & 6.24 & 1.76 & 4.76 & 2.56 & 24.48 \\
\hline Algae 12 & 11.2 & 6.8 & 1.68 & 4.28 & 1.76 & 24.72 \\
\hline Algae 13 & 11.36 & 6.72 & 1.68 & 4.2 & 1.92 & 24.88 \\
\hline
\end{tabular}

Table 4.4 shows that glucose concentrations changed in the presence of xylanase. Xylanase is used to break down xylan from hemicellulose into xylose. In Table 4.4, the results illustrate that xylose was produced without the application of xylanase as evident from samples Algae 8 and 12. Cellulase alone was sufficient to produce a high concentration of xylose. This has been noticed in previous studies of enzymatic hydrolysis of cellulosic materials (Qing et al., 2010). 
This occurred because hemicellulose could also be attacked by cellulase and result in xylose production (Gilbert \& Hazelwood, 1993; Girio et al., 2010). Studies show that xylo-oligomers produced from hemicellulose lead to competitive inhibition of cellulase (Qing et al., 2010; Thirmal and Dahman, 2012). In Table 4.4 sample Algae 8 (treated with two enzymes) showed a total sugar concentration of $26.4 \mathrm{~g} / \mathrm{L}$ which was slightly higher than sample Algae 9 (treated with all three enzymes) which showed a sugar concentration for $26.08 \mathrm{~g} / \mathrm{L}$, this can be credited to the competitive inhibition of cellulase.

It can be seen in Table 4.4 that the thermal pre-treatment had positive effect on the carbohydrate extraction as evidenced from samples Algae 3 and Algae 4. Total sugar concentrations in the hydrolysate have generally higher values in the thermally pre-treated samples than for samples where no heat was applied. Amongst samples treated with heat and other pre-treatments, acid pre-treatment with enzymatic treatment of three enzymes along with heat showed the highest glucose and total sugar concentrations (which samples). The alkaline treatment (samples Algae 6 and 7) showed results similar to samples treated with acid. The higher concentration of $\mathrm{NaOH}$ produced lower sugar concentrations, indicating lower concentrations work better for algal hydrolysis.

The sugar concentrations from samples hydrolysed by acid (samples Algae 1, 2, 3, 4, 12 and 13) illustrates that acid hydrolysis by itself (samples Algae 1 and 2) without any other pre-treatments is quite efficient in conversion of hemicellulose to xylose. Within the biomass, hemicellulose is connected to lignin and cellulose by covalent bonds, but because few hydrogen bonds are involved, it is much more readily broken down into smaller chain oligomers than crystalline cellulose (Jacobsen and Wyman, 2000). Unlike homogeneous cellulose, the heterogeneity of hemicellulose and the resulting variety of hydrolysis reaction mechanisms involved, challenge 
understanding of the hydrolysis process (Brigham et al., 1996). In this study the highest sugar concentrations when treated with acid were observed for sample treated with acid and heat and three enzymes. This would indicate that the $\mathrm{pH}$, which inhibits cellulase, does not affect xylose, which has been known to be active in different optimal $\mathrm{pH}$ and temperature conditions. (Thukral et al., 1989) The data also indicates that $2 \%$ acid treatment is not as effective as $1 \%$. This can be attributed to the less rigid structure of algae, which gets partially oxidised on treatment with higher concentrations of sulfuric acid (Nguyen et al., 2009).

The total sugar concentrations for all the 13 different pre-treated samples were calculated. Thus samples Algae 8 and Algae 9, which used enzymatic pre-treatment, show the best total sugar production, $26.4 \mathrm{~g} / \mathrm{L}$ and $26.08 \mathrm{~g} / \mathrm{L}$ respectively from the breakdown of cellulose and hemicellulose present in algal cell walls. This indicates that for the algal biomass enzymatic pretreatment is essential for breakdown of the cellulosic structure and increasing the bioavailability of sugar monomers thus signifying the important role played by enzymes in breaking down cellulose and hemicellulose.

Traditionally hydrolysis studies have produced higher sugar concentration with acid pretreatment and enzymatic hydrolysis together than only enzymatic pre-treatment. (Volynets and Dahman, 2011) However, the lower total sugar concentration of sample Algae 9 than Algae 8 in this experiment could be accounted for by the reduction in enzymatic activity due to non-optimal $\mathrm{pH}$. All individual sugar and total sugar yields are listed in Table 10 in Appendix C.

The highest sugar values from algal hydrolysis (Sample 8) were compared to pre-treated Wheat Straw hydrolysate (WSH) obtained from WS hydrolysed under similar conditions derived from the literature (Thirmal and Dahman, 2012). The individual and total sugar yield is calculated and 
represented in Table 11 in Appendix C. While the total sugar yield from WSH is $0.69 \mathrm{~g} / \mathrm{g}$, it is only $0.33 \mathrm{~g} / \mathrm{g}$ for algal hydrolysate.

Table 4.5 compares the sugars obtained from WS and algal biomass during pre-treatments. The values form two different pre-treatments are compared, one with acidic and thermal pretreatment and the other with acidic, thermal and enzymatic pre-treatment. WS showed higher concentrations with and without the use of enzymes for hydrolysis. The algal hydrolysis has shown higher values for both mannose and galactose than WS.

Table 4.5 Sugar concentrations from WS and algal biomass

\begin{tabular}{|c|c|c|c|c|c|c|c|}
\hline Feedstock & Pre-treatment & $\begin{array}{c}\text { Glucose } \\
(\mathrm{g} / \mathrm{L})\end{array}$ & $\begin{array}{c}\text { Xylose } \\
\text { (g/L) }\end{array}$ & $\begin{array}{l}\text { Arabinose } \\
\text { (g/L) }\end{array}$ & $\begin{array}{c}\text { Mannose } \\
\text { (g/L) }\end{array}$ & $\begin{array}{c}\text { Galactose } \\
(\mathrm{g} / \mathrm{L})\end{array}$ & $\begin{array}{c}\text { Total } \\
\text { sugars } \\
\text { (g/L) }\end{array}$ \\
\hline WS & Acid + Thermal ${ }^{[\mathrm{a}]}$ & 16 & 10 & 1.5 & 0.1 & 2.2 & 29.8 \\
\hline Algae & Acid + Thermal ${ }^{[\mathrm{a}]}$ & 8.88 & 5.68 & 1.68 & 4.76 & 2.8 & 22.8 \\
\hline WS* & $\begin{array}{l}\text { Acid + Thermal+ } \\
\text { Enzymatic }^{[\mathrm{b}]}\end{array}$ & 25.5 & 13.5 & 4.8 & 2.8 & 2.2 & 48.8 \\
\hline Algae & $\begin{array}{l}\text { Acid + Thermal+ } \\
\text { Enzymatic }^{[\mathrm{b}]}\end{array}$ & 12.48 & 6.56 & 1.6 & 4.68 & 2.8 & 26.4 \\
\hline
\end{tabular}

[a] $1 \%$ Acid $(\mathrm{v} / \mathrm{v})+121^{\circ} \mathrm{C}$ for $30 \mathrm{~min}$

[b] $1 \%$ Acid (v/v) $+121{ }^{\circ} \mathrm{C}$ for $30 \mathrm{~min}+$ Xylanase, Cellulase, and $\beta$-glucosidase

* Study conducted previously at the Nanocomposite and Biomaterials Lab, Ryerson University (Thirmal and Dahman, 2012)

Table 4.6 displays the cellulosic makeup of algal biomass. The values for algae were calculated from sugar values derived from the algal hydrolysis study and calculated according to the 
method in Chapter 3.5 (Ververis et al., 2008). This is compared with WS and corn stover values from literature. Amongst WS, algal biomass and corn stover, the latter has the highest cellulose value at $64.1 \%$ of the weight of a stover as shown in Table 4.5, whereas WS has the highest hemicellulosic content at $32.8 \%$. The algal values are corresponding closely with those reported previously in the literature (Harun and Danquah, 2011; Ververis et al., 2007). The clorococum species of algae studied had about $10 \%$ of xylose and $15 \%$ of glucose (Ververis et al., 2007).

Table 4.6 Composition of algal biomass in the present study compared to WS and Corn Stover compositions from literatures

\begin{tabular}{|c|c|c|l|}
\hline Feedstock & Cellulose (\%w/w) & Hemicellulose $\mathbf{( \% \mathbf { w } / \mathbf { w } )}$ & Reference \\
\hline Algae & 16.6 & 11.8 & Present study \\
\hline WS & 38 & 32.8 & Bjerre et al., 1996 \\
\hline Corn Stover & 64.1 & 24.6 & Zhao \& Xia, 2010 \\
\hline
\end{tabular}

As can be observed from Table 4.6, the amount of cellulose and hemicellulose in algae is about half of that of wheat straw and corn stover. Thus algae has less potential to generate sugars which can be converted to biofuel, polymers and the like. However, an advantage is that algae are easier to break down than wheat straw and corn stover thus requiring less energy. Also the absence of an inhibitor is attractive, which is due to lack of furfural releasing lignin in algal biomass (Ververis et al., 2007). Additionally, the sugars being extracted from the biomass are in addition to the lipids that has been extracted from them, which are also used to produce biofuel. Thus the energy content of algae is quite high.

Following the algal hydrolysis study, SSF of algal biomass was conducted with the mutated strain showing the highest biobutanol yield. Four different pre-treatments were used. (see Section 
3.2.4). SSF was carried for the four samples and sample $A 3$ showed the maximum ABE yield as presented in Table 13 in appendix C (i.e. $0.48 \mathrm{~g} / \mathrm{g}$ ). The solvents produced during the SSF were analysed and Table 4.7 details the different concentrations of ABE solvents produced. The values of butanol and total $\mathrm{ABE}$ concentrations $(7.52 \mathrm{~g} / \mathrm{L}$ and $12.68 \mathrm{~g} / \mathrm{L})$ are higher than the ones reported in the literatures $(5.61 \mathrm{~g} / \mathrm{L}$ and $9.74 \mathrm{~g} / \mathrm{L}$, respectively). This when xylanase and cellulase enzymes were supplemented to the pre-treated algae media and the bacterial species used was clostridium saccharoperbutylacetonicum (Ellis et al., 2012).

Table 4.7 ABE production values using algal biomass as feedstock at 120 hours of SSF

\begin{tabular}{|c|c|c|c|c|c|c|c|}
\hline Sample & $\begin{array}{c}\text { Total Sugar } \\
\text { consumed } \\
(\mathbf{g} / \mathbf{L})\end{array}$ & $\begin{array}{c}\text { Acetone } \\
(\mathrm{g} / \mathbf{L})\end{array}$ & $\begin{array}{c}\text { Butanol } \\
(\mathrm{g} / \mathbf{L})\end{array}$ & $\begin{array}{c}\text { Ethanol } \\
(\mathrm{g} / \mathbf{L})\end{array}$ & $\begin{array}{c}\text { Acetic } \\
(\mathbf{g} / \mathbf{L})\end{array}$ & $\begin{array}{c}\text { Butyric } \\
\text { Acid } \\
(\mathbf{g} / \mathbf{L})\end{array}$ & $\begin{array}{c}\text { Total } \\
\text { ABE } \\
(\mathbf{g} / \mathbf{L})\end{array}$ \\
\hline A1 & 21.26 & 2.8 & 6.2 & 0.9 & 0.54 & 0.5 & 9.9 \\
\hline A2 & 24.96 & 4.58 & 7.3 & 1.18 & 0.8 & 0.7 & 12.06 \\
\hline A3 & 26.76 & 4.77 & 7.52 & 1.39 & 1 & 0.86 & 12.68 \\
\hline A4 & 24.3 & 4.5 & 7.2 & 1.08 & 0.7 & 0.7 & 11.78 \\
\hline
\end{tabular}

As can be grasped from Table 4.7 the sample with acid treatment and enzymatic treatment, sample A3 showed the best production of butanol. This is comparable to sample A2 which was pre-treated with acid along with thermal treatment. The concentration of $\mathrm{ABE}$ products generated during the SSF of algal biomass are approximately similar for the different pre-treated samples of SSF. Samples pre-treated with enzymes show concentration of ABE at $12.06 \mathrm{~g} / \mathrm{L}$ while production of $11.78 \mathrm{~g} / \mathrm{L}$ was observed without the use of enzymatic pre-treatment. This illustrates that the fused cells produced enzymes to break down cellulose and hemicellulose and 
don't require additional enzymes in pre-treatment step of the SSF. The yield of biobutanol, acetone, ethanol and acids produced during SSF of the algal biomass is presented in Table 11 of Appendix C.

Table 4.8 compares the butanol and ABE yields generated from SSF of algal biomass with WS. The lower levels of yield for algal biomass indicate the presence of possible inhibitors (Ezeji et al., 2004). A previous study conducted suggests the removal of algal solids after hydrolysis increases productivity (Potts et al., 2011). This indicates possible inhibition from the substrate or presence of other inhibitors.

\section{Table 4.8 Butanol and ABE yield comparison from SSF experiments using WS and algal biomass as feedstocks}

\begin{tabular}{|c|c|c|}
\hline Feedstock & Biobutanol (w/w) & ABE (w/w) \\
\hline WS & 0.36 & 0.6 \\
\hline Algal & 0.28 & 0.48 \\
\hline
\end{tabular}

Wheat straw produced higher biobutanol and $\mathrm{ABE}$ yield when compared to algal biomass. The algal SSF process needs to be optimised to achieve similarly high yields as of WS and possible inhibitors investigated. Nonetheless, when productivity is calculated in terms of land use, realistic estimates for productivity for algae are in the order of magnitude of 40-80 tons of dry matter per year per hectare, depending on the technology used and the location of production (Chisti, 2007). This is still substantially higher than almost all agricultural crops as detailed in Table 4.9. Thus on a productivity basis, algal biomass would produce more butanol per hectare of harvest. 
Table 4.9 Productivity of cellulosic feedstock as determined from literature

\begin{tabular}{|c|c|l|}
\hline Feedstock & Productivity (dry Mg/ha yr) & Reference \\
\hline Corn & 7 & Dismukes et al., 2008 \\
\hline Switch grass & $4.5-15$ & David and Ragaukas, 2006 \\
\hline Wheat Straw & 44 & Woods and Layzell, 2003 \\
\hline Algae (Chlorella species) & $40-80$ & Chisti 2007 \\
\hline
\end{tabular}

The high per hectare productivity along with useful characteristics like less water use, less land use, and ease of growing makes algal species a lucrative feedstock. Technological advances are required to harness the energy available in algae and make them the feedstock of the future. Surpassing yields of 80 tons per year per hectare will likely require genetically improved strains or other technologies able to counteract photo-saturation (light induced plateau-ing of photo synthetic activity) and photo-inhibition (light-induced reduction in the photosynthetic capacity) (Tredici 2010).

\subsection{Oxygen Tolerance Studies}

Clostridia are obligate anaerobes, showing aerotolerance (Kato et al.,2004).The clostridia strain was further subjected to aero-tolerance studies. Figure 4.14 represents the cell count of the mutated species grown aerobically and anaerobically. It is evident that the aerobic conditions inhibit growth; however, the minimal growth observed in aerobic conditions indicate some tolerance to oxygen, albeit the growth was much slower in comparison with the sample grown in anaerobic conditions. As seen in Figure 4.15, the sample exposed to air showed less growth and were inhibited due to the presence of oxygen. The bacterial cell count went down (23\% of initial) in the first 8 hours as cells died due to being exposed to oxygen, but then revived showing 
adaptation and aerotolerance. (Hillman et al., 2008). The final cell concentration after $24 \mathrm{~h}$ in cells grown aerobically was $1.3 \times 10^{5}$ cells/ml. This was very low as compared to cells grown anaerobically $\left(2.4 \times 10^{6}\right.$ cells $\left./ \mathrm{ml}\right)$. The cell colony morphology was compared with other mutated $\mathrm{CbCt}$ strains to ascertain the identity of the species and was found to be in accordance with clostridium fused strains.

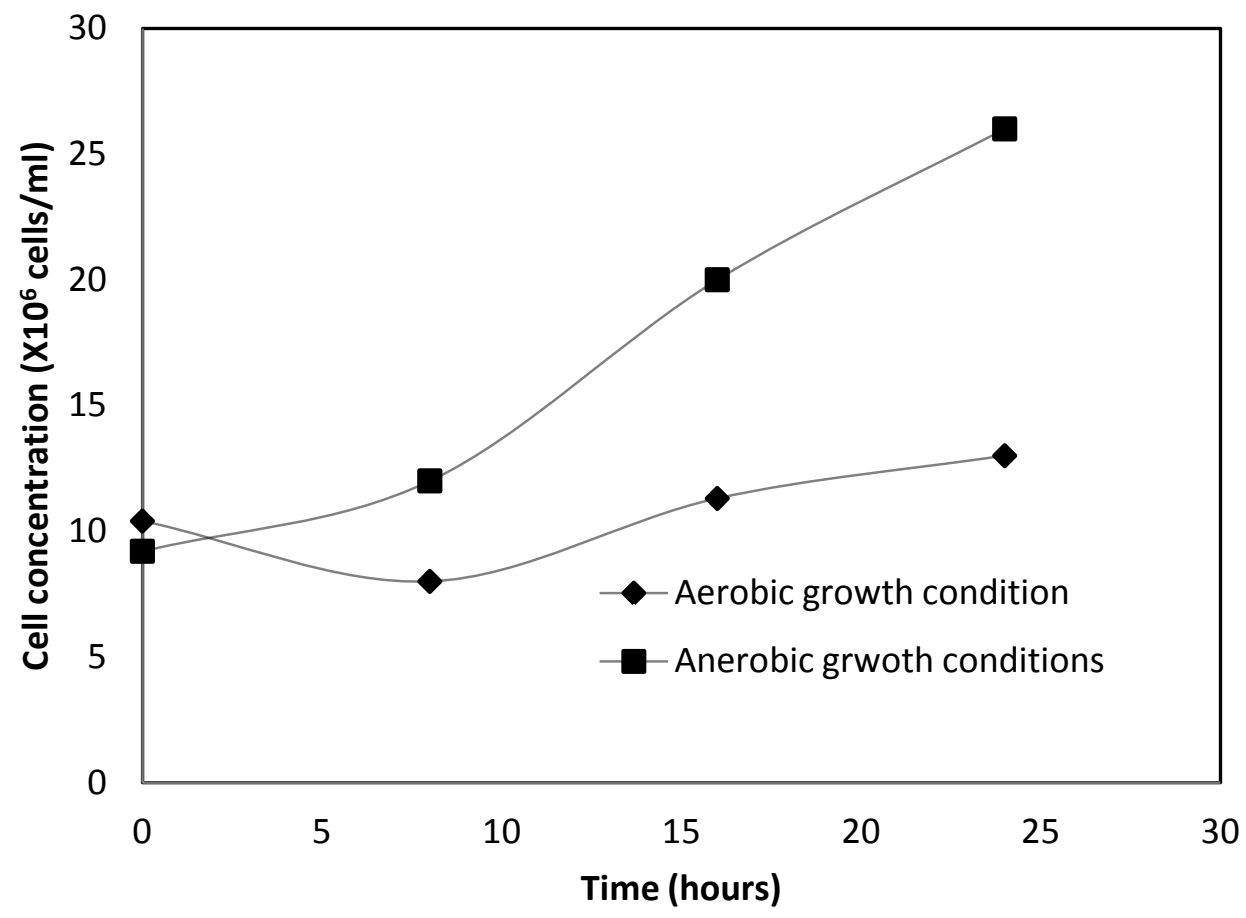

Figure 4.15 Cell count for samples grown in aerobic conditions compared with sample grown in anaerobic conditions

SSF capabilities of the strain were investigated under aerobic and anaerobic conditions. This was done to eliminate the possibility of contamination by common aerobic bacterial species and to ascertain the effect of oxygen on SSF capabilities of the mutated strain. SSF with WS and the resulting solvent production proved that the possibility of contamination by other aerobic species was minimal. The study also examined the effect of oxygen on SSF capabilities of the mutated strain. The results indicate that whereas the sample grown in anaerobic conditions showed the 
usual biobutanol concentration $(13.9 \mathrm{~g} / \mathrm{L})$, the ones incubated in presence of oxygen were not as effective, but showed some minor production $(1.73 \mathrm{~g} / \mathrm{L}$ of butanol). Figure 4.16 shows the concentration of various products produced during SSF of WS conducted in presence of oxygen and in strict anaerobic conditions.

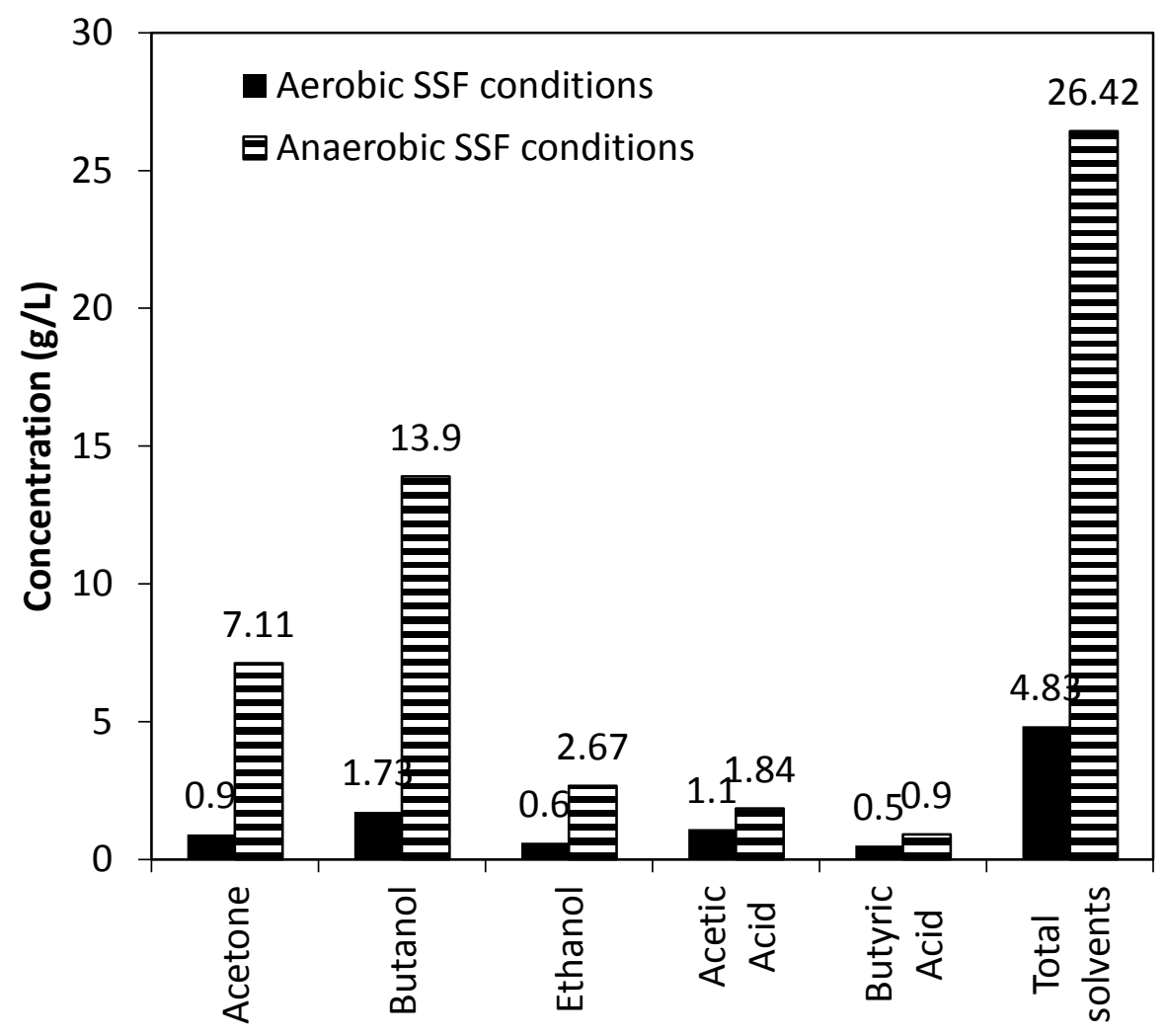

Figure 4.16 ABE production for SSF in aerobic conditions compared to SSF in anaerobic conditions

Figure 4.16 demonstrates that there was no contamination with other aerobic strains as the cells grown in presence of air did show solvent production by the ABE method. Sugar was utilised and acetone, biobutanol, ethanol as well as acetic acid and butyric acid were produced. This indicated aerotolerance of the bacterial strains. This has great potential for future production, if the strains can be trained to be fully functional in presence of air, anaerobic conditions need not 
be maintained. This has the potential to reduce the cost of the whole process associated with maintaining anaerobicanaerobic conditions, making it economically more attractive. 


\section{CHAPTER FIVE \\ CONCLUSIONS AND RECOMMENDATIONS}

\subsection{Conclusion}

The present study focussed on enhancing biobutanol production from cellulosic feedstocks. WS and algal biomass were both studied for their suitability as feedstocks. The fused bacterial strains were mutated using UV radiation and EMS, a chemical mutagen to increase resistance to biobutanol toxicity. The biobutanol toxicity resistance of the strains was raised to $15 \mathrm{~g} / \mathrm{L}$ an increase of $15 \%$ from literature value of $13 \mathrm{~g} / \mathrm{L}$ (Qurat-ul-Ain Syed et al., 2008). ABE studies on wheat straw were conducted with these enhanced bacterial strains. Moreover, mutated strains in general showed superiority in terms of biobutanol production compared to parent strains of fused $C b C t$. As described in the text, fused strains showed biobutanol concentration of $14.6 \mathrm{~g} / \mathrm{L} \mathrm{a}$

minor increase over fused parent strain of $C b C t$ which produced a maximum of $13.8 \mathrm{~g} / \mathrm{L}$. An increase in biobutanol production yield of 5.8\% was observed from the fused strains developed in the lab previously, indicating that the mutated strains were better able to handle biobutanol toxicity and thus showed higher yield of biobutanol. The growth condition for the mutated strain was studied to determine the aero-tolerance of strains. Strains were found to be slightly aero tolerant. Following the enhancement of bacterial strains, further analysis of cellulosic algal biomass as a feedstock was conducted to determine its cellulosic makeup and suitability as a potential feedstock.

A bio-refinery approach was applied and the cellulosic makeup of the algal biomass was studied. The algal biomass was processed using different methods of chemical, thermal and enzymatic hydrolysis. This pre-treated biomass was then processed using simultaneous saccharification and 
fermentation (SSF) using the mutated strain, which showed the best results during the mutation studies. The ABE yield of $0.48 \mathrm{~g} / \mathrm{g}$ was calculated. This is higher than literature value of $0.311 \mathrm{~g} / \mathrm{g}$ (Elli et al., 2012), obtained with the addition of enzymes during the pre-treatment of algal biomass.

\subsection{Future Study Recommendations}

Evaluating the mutated strains to understand their full potential, the author suggests performing SSF studies using the mutated strain on a scaled up reactor that would mimic industrial production. Pilot scale batch reactors pose additional advantages such as continuous removal of toxic biobutanol, $\mathrm{pH}$ and acid control during SSF when compared to laboratory scale batch processes. Hence, the author believes that the true potential of the strains developed in this study can be thoroughly examined in a pilot scale reactor.

While performing SSF in a batch reactor using the novel mutated strains, the author also suggests the use of gas stripping and $\mathrm{pH}$ control to further reduce the effect of biobutanol toxicity on these strains. A combination of gas stripping, $\mathrm{pH}$ control and genetically improved protoplast fused strains has the potential to produce high levels of biobutanol.

Butanol production from algal biomass has not been investigated heavily, thus an important step would be further investigation of butanol production from algal biomass (Jang et al., 2012).

In terms of metabolic improvement to strains and feedstock improvement, this work can be further extended by

1. Direct genetic manipulation of bacterial strains to increase yields (Lee et al., 2008)

2. Enhancing oxygen tolerance of strains through genetic engineering (Luque et al., 2010) 
3. Genetic manipulation of plants to increase cellulose yields (Fu et al., 2011; Sticklen 2008)

The ability to engineer novel methods to produce these high value products from an abundant and renewable feedstock such as algae and wheat straw could have significant implications in stimulating domestic energy production. It is being estimated that by 2022 eight percent of the global fuel volumes consumed by transportation will be biofuels. (Kagan, 2010). A lot of this will be met by first generation biofuels. First generation biofuels are cheaper and easier to produce right now, but use food and arable land to produce energy which would prove to be unsustainable in the future. Thus there is a need for more sustainable, cellulosic fuels to be more readily adopted as the future of biofuels. To achieve this, cellulosic fuels need to be cheaper and thus commercially attractive. By increasing yields we are making the product biobutanol, commercially viable by increasing the ERoI. This would make it competitive with first generation biofuels and help with its adoption by the market as a transportation fuel.

Algal biodiesel is often referred to as the $3^{\text {rd }}$ generation of biofuels. Algae produce triglycerides that are extracted and converted in a refinery to produce bio-diesel. Producing biodiesel from algae is widely regarded as one of the most efficient ways of generating biofuels and has great potential to replace gasoline/diesel demand in transport (Pabbi et al., 2011).

Biodiesel can not only be produced from Algae, but also once the oil is extracted the remaining biomass of algae can be utilized as a renewable and sustainable resource for carbon that can replace agriculture residues to produce biofuels such as ethanol and biobutanol. (Potts et al., 2012). Algae are known to produce biomass faster and on reduced land areas as compared with lignocellulosic biomass (Lee and Lavoie, 2013). Algae can be further modified genetically to increase yields of biofuels (Radakovits et al., 2010). 
Recently a $4^{\text {th }}$ generation biofuel has been proposed where the biofuels are created using petroleum-like hydroprocessing or advanced biochemistry. The 4th generation of biofuels has introduced the concept of cell factory" (Lu et al., 2011). Studies on metabolic engineering of algae to increase the photosynthetic ability of the cell to produce higher yield of fuel faster has shown promise (Lu et al., 2011). Joule Biotechnologies solar-to-fuel model uses sunlight, waste $\mathrm{CO}_{2}$ and engineered microorganisms in a "solar converter" to create fuel (Kagan, 2010). Also with the ultimate aim of developing renewable sustainable fuel for the future, research needs to be conducted in $3^{\text {rd }}$ and $4^{\text {th }}$ generation biofuels. 


\section{APPENDICES}

\section{Appendix A Chemicals used in the current study}

Table A.1 List of chemicals used in the current study

\begin{tabular}{|c|c|c|}
\hline Product & Company & Catalogue No. \\
\hline Glucose & Sigma-Aldrich (St. Louis, MO) & G8769 \\
\hline D-biotin & Sigma-Aldrich (St. Louis, MO) & B4501 \\
\hline PABA & Sigma-Aldrich (St. Louis, MO) & 6930 \\
\hline Thiamine- $\mathrm{HCl}$ & Sigma-Aldrich (St. Louis, MO) & T4625 \\
\hline $\mathrm{FeSO}_{4} \cdot 7 \mathrm{H}_{2} \mathrm{O}$ & Sigma-Aldrich (St. Louis, MO) & F8048 \\
\hline $\mathrm{MnSO}_{4} \cdot 4 \mathrm{H}_{2} \mathrm{O}$ & Sigma-Aldrich (St. Louis, MO) & M7634 \\
\hline $\mathrm{MgSO} 4.7 \mathrm{H}_{2} \mathrm{O}$ & Sigma-Aldrich (St. Louis, MO) & 63138 \\
\hline $\mathrm{H}_{2} \mathrm{SO}_{4}$ & Sigma-Aldrich (St. Louis, MO) & 339741 \\
\hline $\mathrm{KH}_{2} \mathrm{PO}_{4}$ & Sigma-Aldrich (St. Louis, MO) & 322431 \\
\hline $\mathrm{K}_{2} \mathrm{HPO}_{4}$ & Sigma-Aldrich (St. Louis, MO) & GO139 \\
\hline $\mathrm{NaOH}$ & Sigma-Aldrich (St. Louis, MO) & S5881 \\
\hline Poly ethylene glycol (PEG) & Sigma-Aldrich (St. Louis, MO) & $\mathrm{X} 2753$ \\
\hline Casein hydrolysate & Sigma-Aldrich (St. Louis, MO) & 22090 \\
\hline$\left(\mathrm{NH}_{4}\right)_{2} \mathrm{SO}_{4}$ & Sigma-Aldrich (St. Louis, MO) & 7783202 \\
\hline Agar & Sigma-Aldrich (St. Louis, MO) & 05038 \\
\hline Xylanase & Sigma-Aldrich (St. Louis, MO) & X2629 \\
\hline Cellulase & Sigma-Aldrich (St. Louis, MO) & $\mathrm{C} 11184$ \\
\hline$\beta$-glucosidase & Sigma-Aldrich (St. Louis, MO) & G4511 \\
\hline
\end{tabular}




\section{Appendix B Sugars, ABE, and acids Standard Calibration Curves (HPLC)}

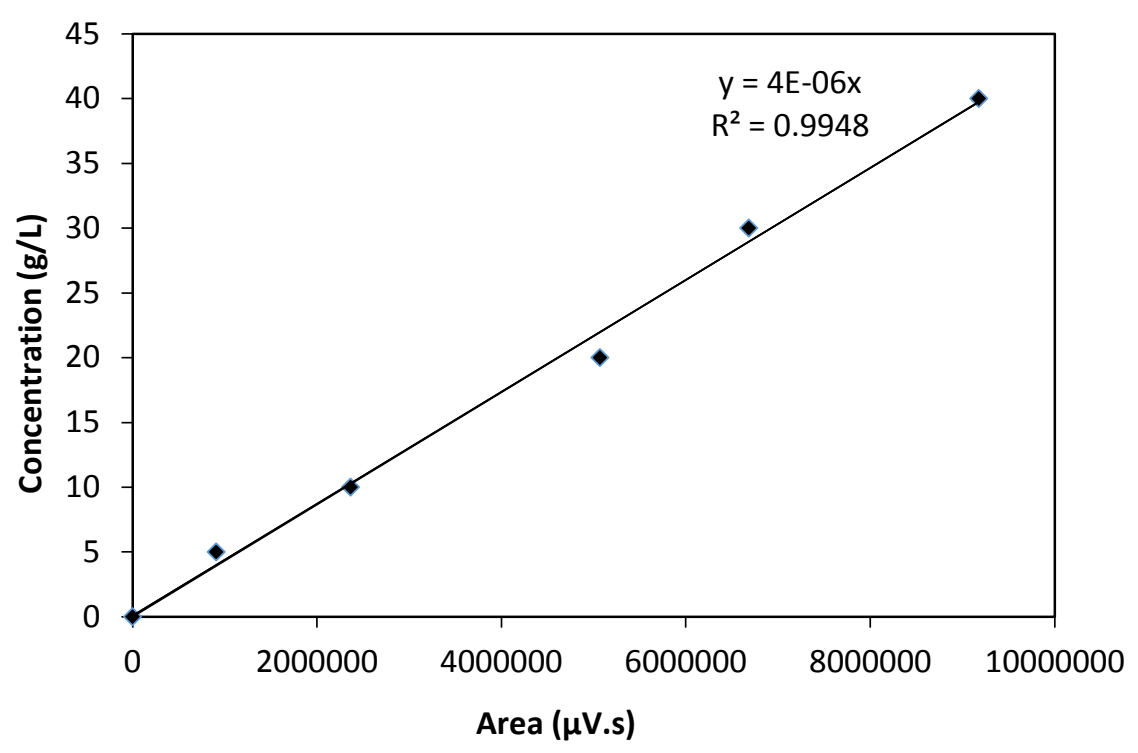

Figure B.1 HPLC calibration curve for Glucose

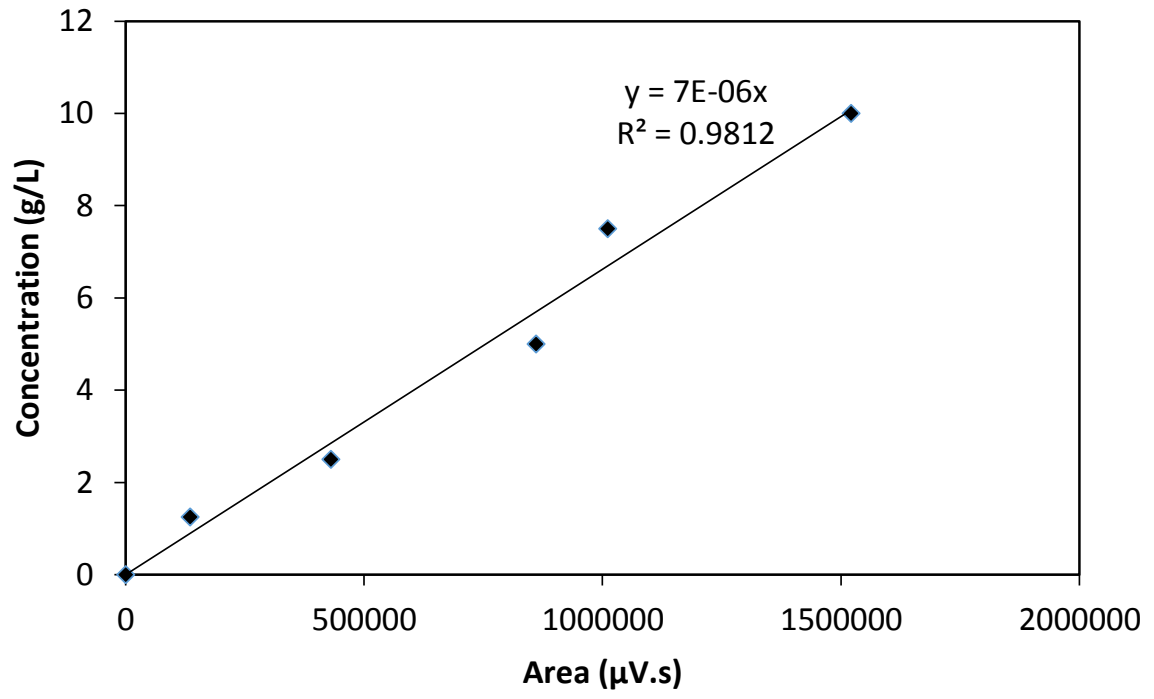


Figure B.2. HPLC calibration curve for Galactose

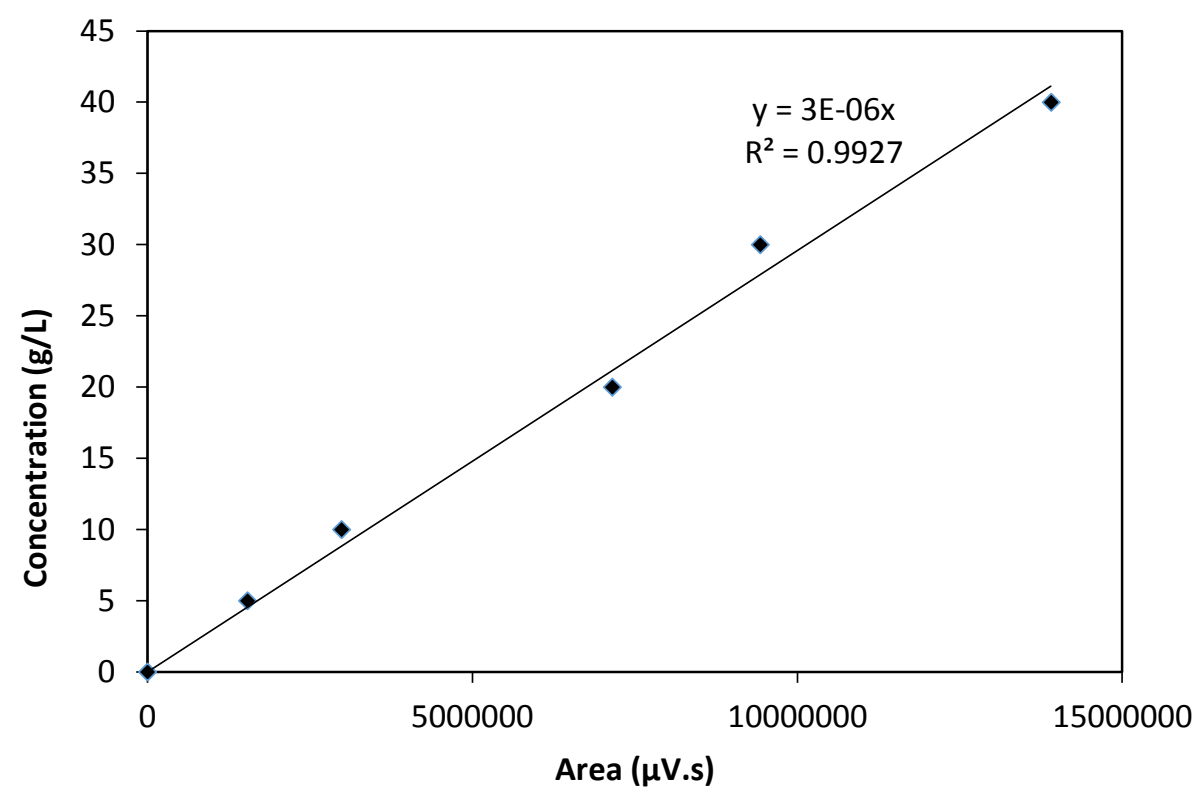

Figure B.3. HPLC calibration curve for Xylose

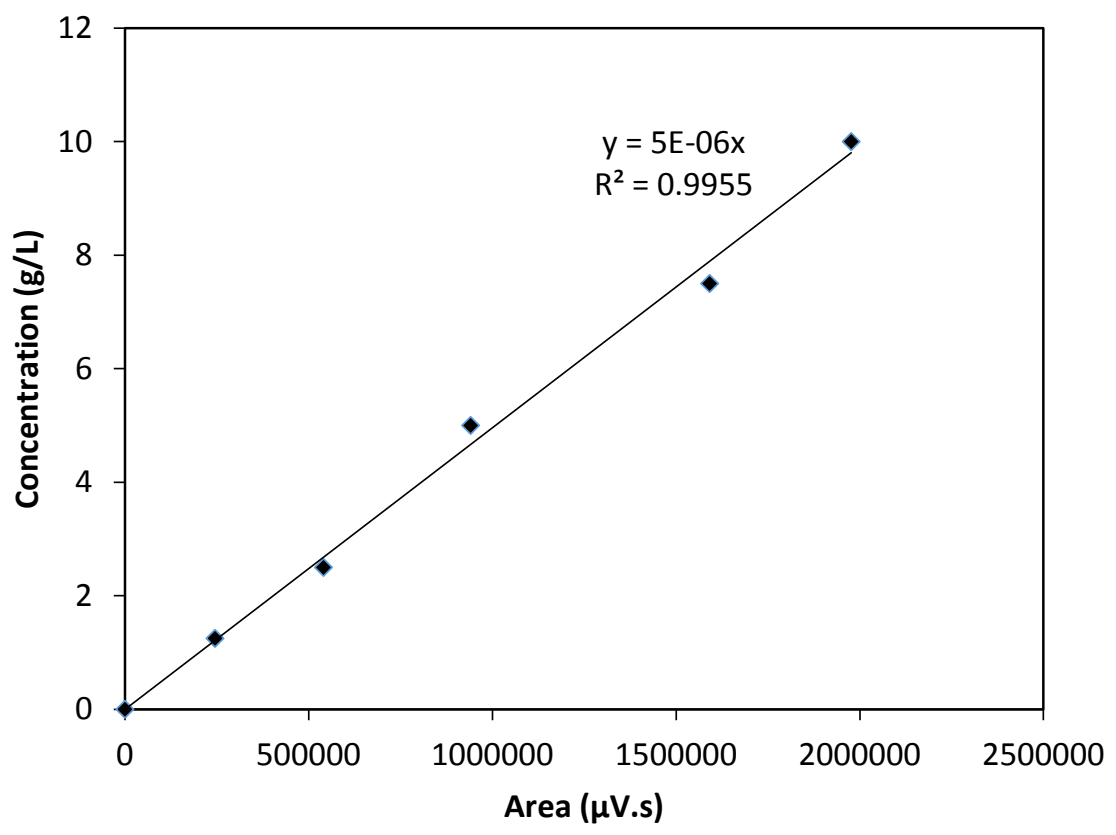


Figure B.4. HPLC calibration curve for Mannose

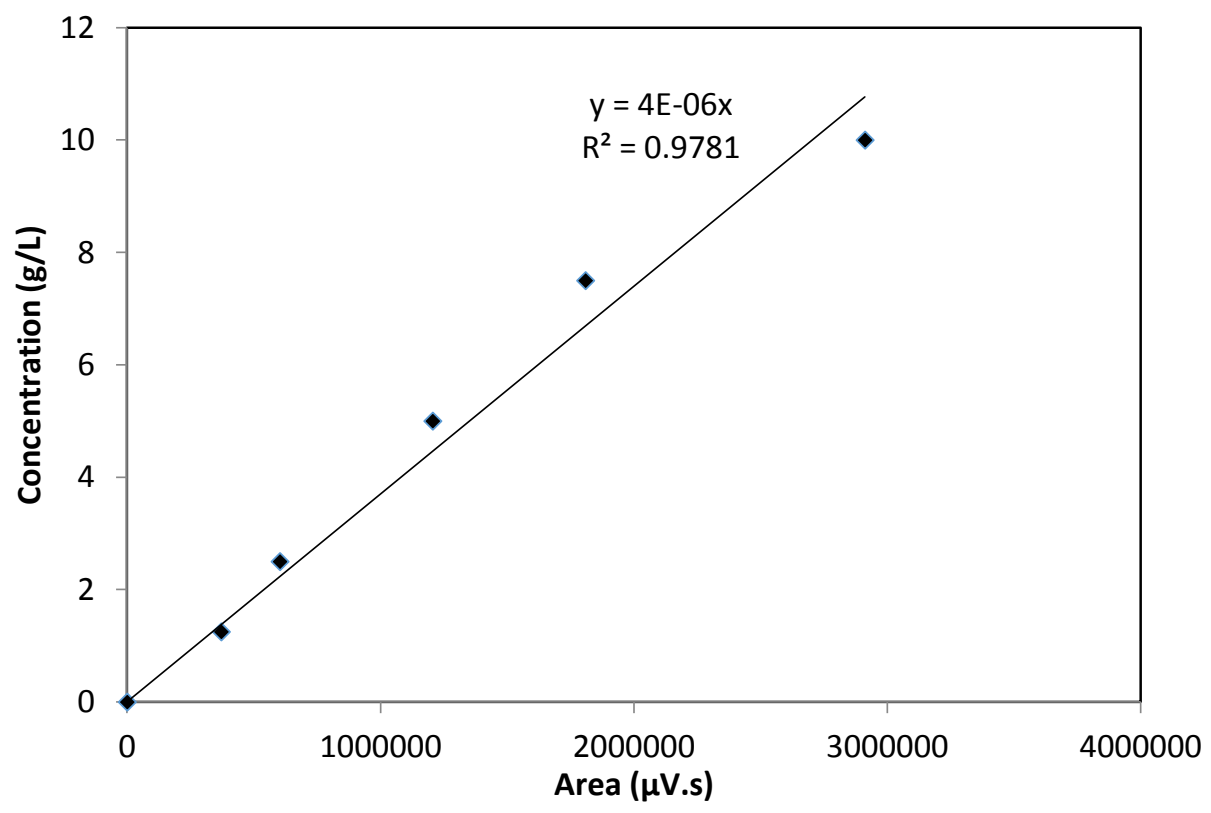

Figure B.5. HPLC calibration curve for Arabinose

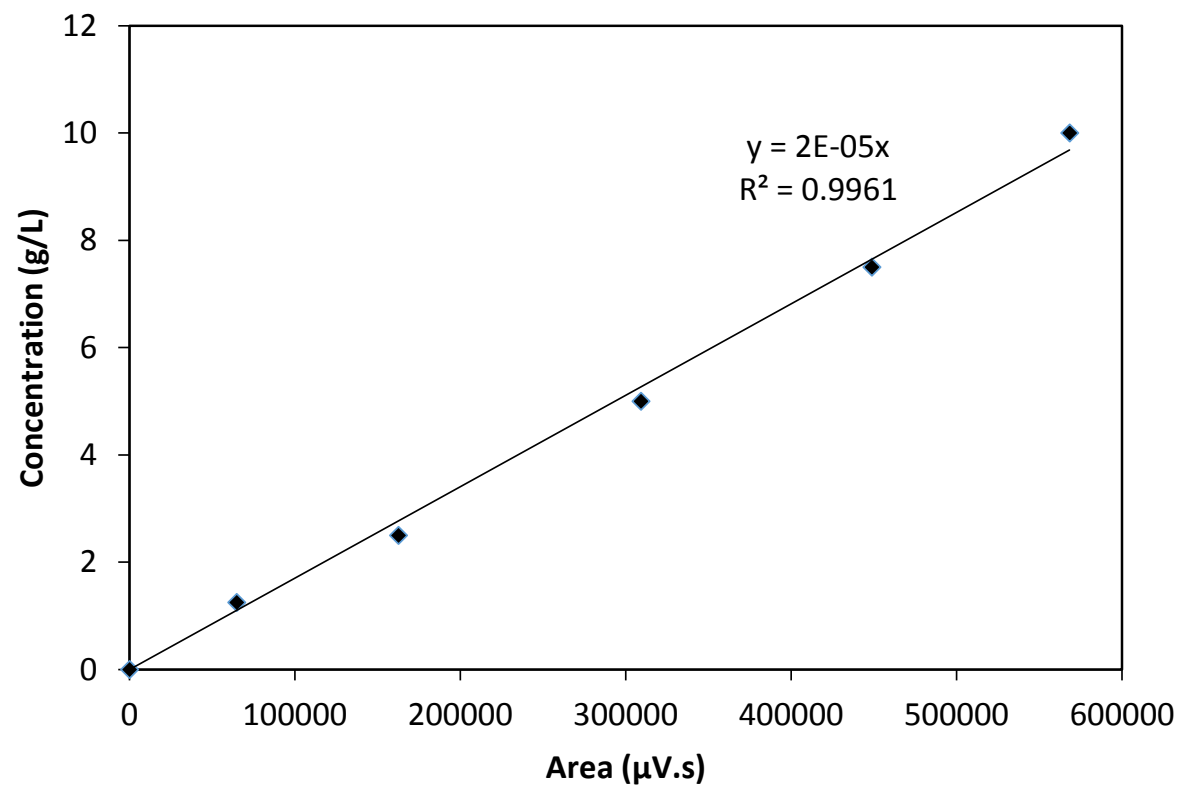


Figure B.6. HPLC calibration curve for Acetone

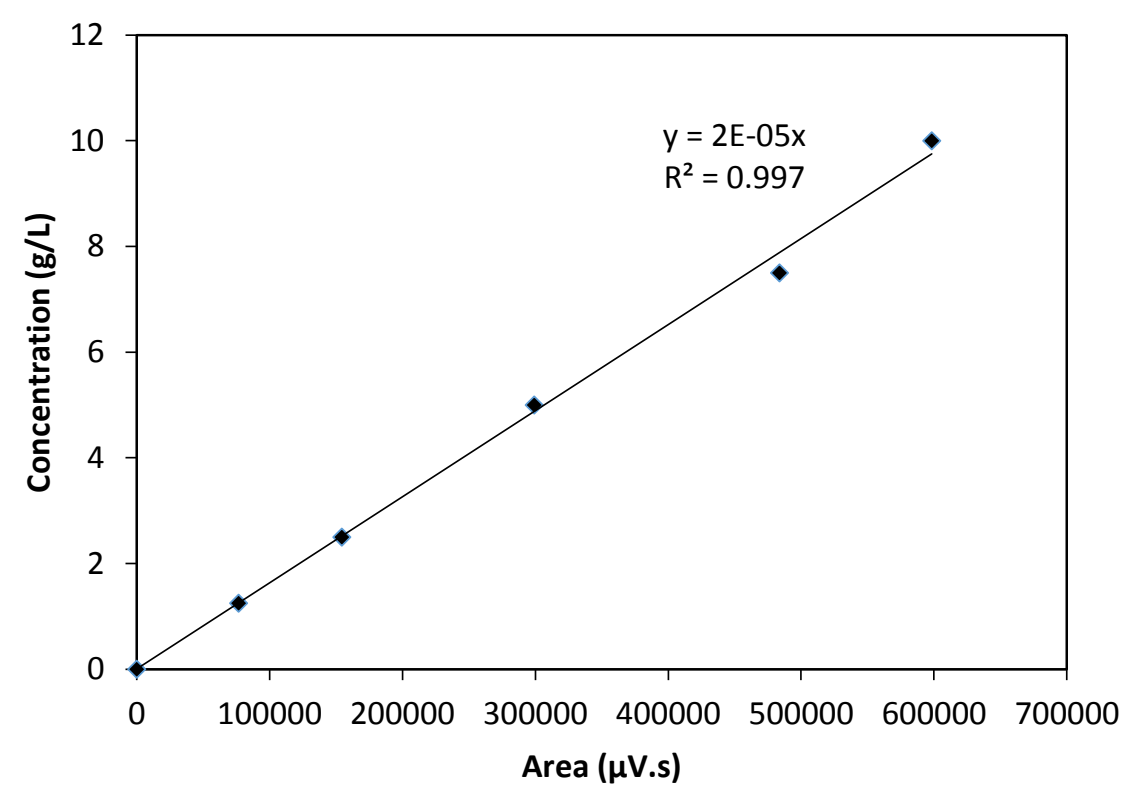

Figure B.7. HPLC calibration curve for Biobutanol

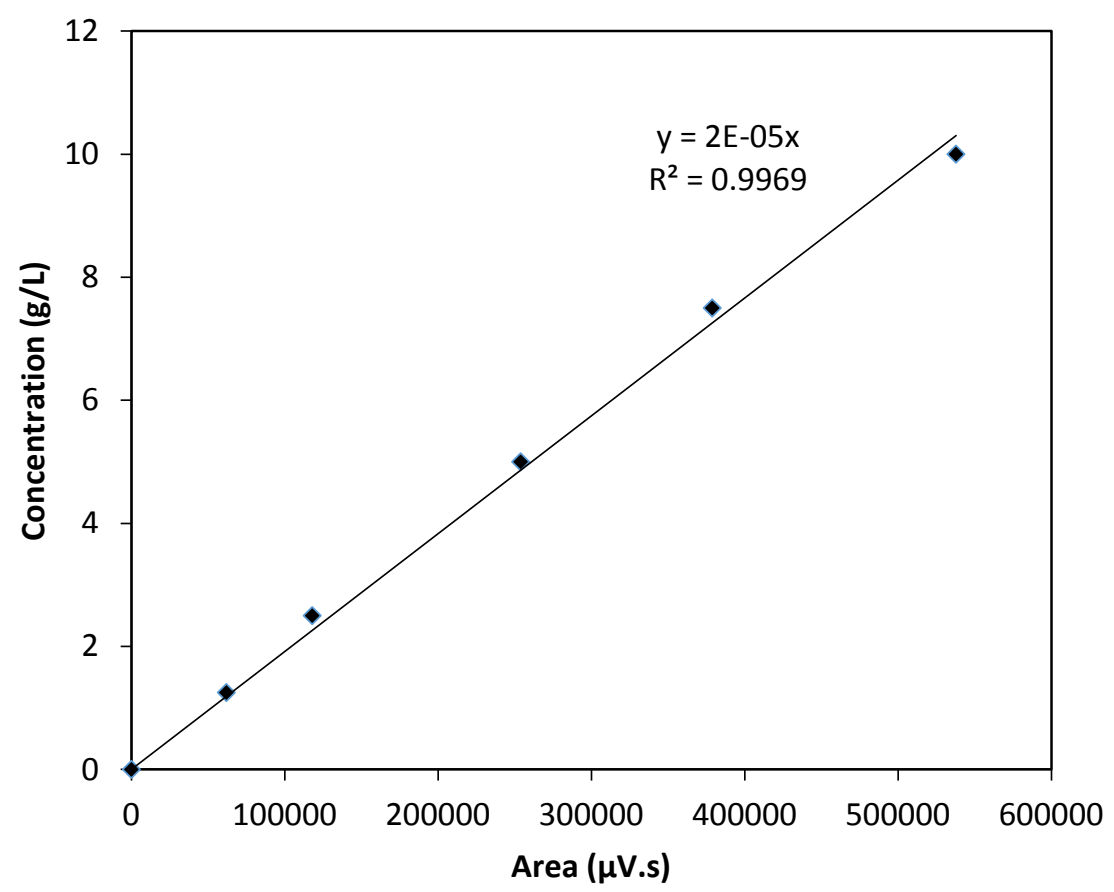


Figure B.8. HPLC calibration curve for Ethanol

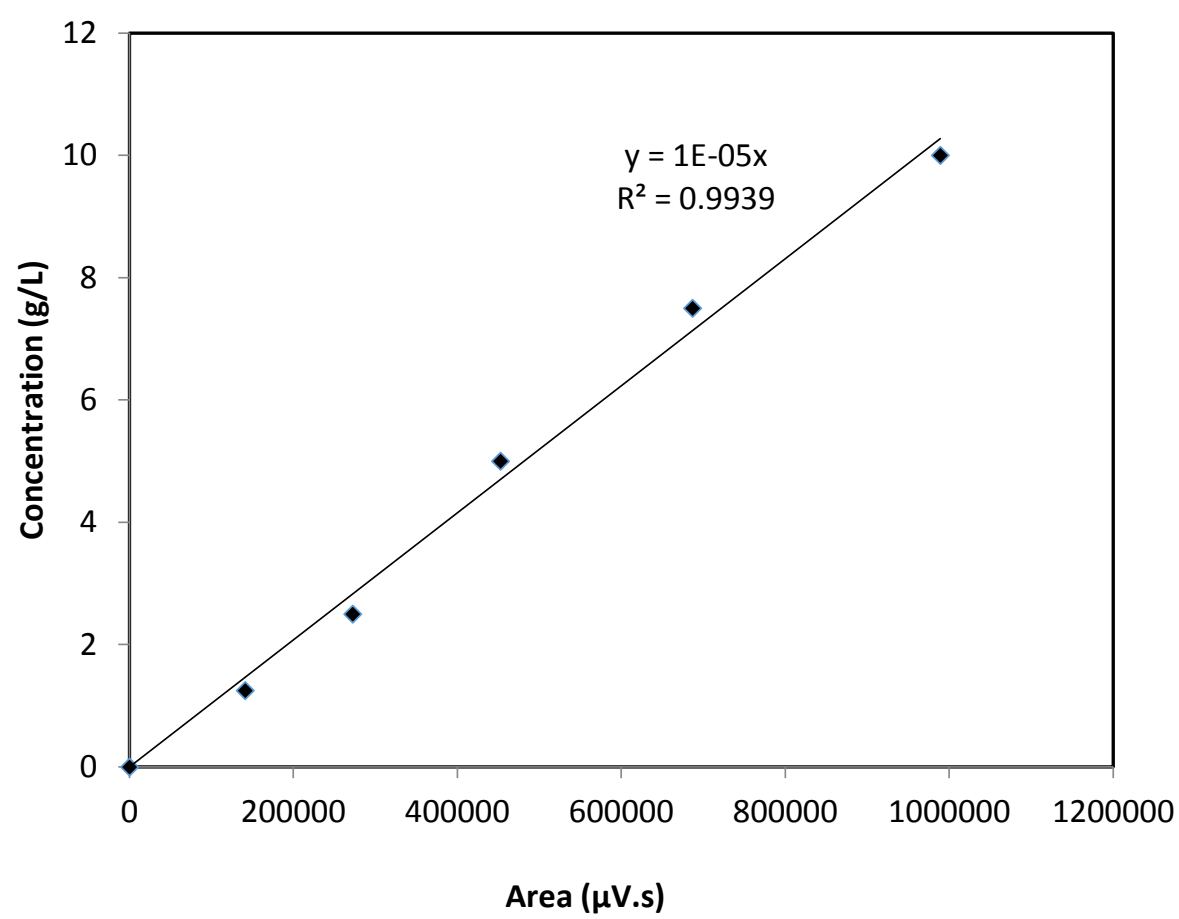

Figure B.9. HPLC calibration curve for Acetic acid

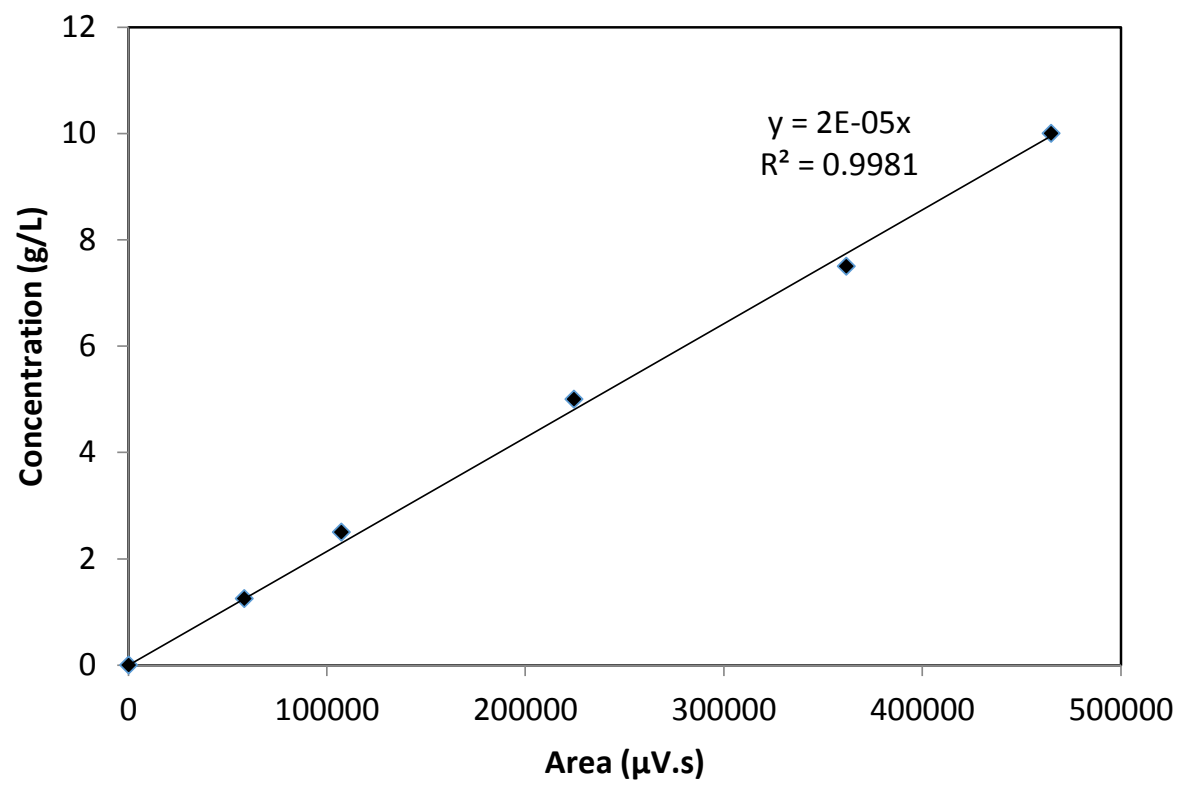


Figure B.10. HPLC calibration curve for Butyric acid

\section{Appendix $\mathrm{C}$ Raw data for mutagenesis, sugar profile, ABE and acids produced during SSF of WS and algal biomass}

Table C.1 Cell count associated with EMS mutation

\begin{tabular}{|c|c|c|c|}
\hline & Time (min) & $\begin{array}{c}\text { Cell count in } \\
\text { presence of } \mathbf{1 5} / \mathbf{l} \\
\text { butanol }(\mathbf{X 1 0} \\
\text { cells/ml })\end{array}$ & $\begin{array}{c}\text { Cell count in } \\
\text { presence of } \mathbf{1 6 g} / \mathbf{l} \\
\text { cells/ml })\end{array}$ \\
\hline 0 & 27 & 0.2 & 0 \\
\hline 20 & 23 & 0.23 & 0 \\
\hline 40 & 18 & 0.24 & 0 \\
\hline 50 & 17 & 0.178 & 0 \\
\hline 60 & 7 & 0.055 & 0 \\
\hline
\end{tabular}

Table C.2 Cell count associated with UV mutation

\begin{tabular}{|c|c|c|c|}
\hline Time (min) & $\begin{array}{c}\text { Cell count }\left(\mathrm{X}^{5} 0^{5}\right. \\
\text { cells } / \mathrm{ml})\end{array}$ & $\begin{array}{c}\text { Cell count in } \\
\text { presence of } 15 \mathrm{~g} / \mathrm{l} \\
\text { butanol }\left(\mathrm{X10}^{5}\right. \\
\text { cells } / \mathrm{ml})\end{array}$ & $\begin{array}{c}\text { Cell count in } \\
\text { presence of } 16 \mathrm{~g} / \mathrm{l} \\
\text { butanol }\left(\mathrm{X}^{\mathrm{l}} \mathbf{5}^{5}\right. \\
\text { cells } / \mathrm{ml})\end{array}$ \\
\hline 0 & 28 & 2 & 0 \\
\hline 5 & 26 & 9 & 0 \\
\hline 10 & 19 & 14 & 0 \\
\hline 15 & 14 & 12 & 0 \\
\hline 20 & 9 & 0 & 0 \\
\hline 25 & 5 & 0 & 0 \\
\hline 30 & 2 & 0 & 0 \\
\hline
\end{tabular}


Table C.3 Sugar concentration profile by non-mutated strain S1

\begin{tabular}{|l|l|l|l|l|l|l|}
\hline $\begin{array}{l}\text { Time } \\
(\text { hours) }\end{array}$ & $\begin{array}{l}\text { Glucose } \\
(\mathrm{g} / \mathbf{L})\end{array}$ & $\begin{array}{l}\text { Xylose } \\
(\mathrm{g} / \mathbf{L})\end{array}$ & $\begin{array}{l}\text { Arabinose } \\
(\mathrm{g} / \mathbf{L})\end{array}$ & $\begin{array}{l}\text { Mannose } \\
(\mathrm{g} / \mathbf{L})\end{array}$ & $\begin{array}{l}\text { Galactose } \\
(\mathrm{g} / \mathbf{L})\end{array}$ & $\begin{array}{l}\text { Total sugars } \\
(\mathrm{g} / \mathbf{L})\end{array}$ \\
\hline 0 & 16 & 10 & 1.5 & 0.1 & 2.2 & 29.8 \\
\hline 24 & 26.6 & 12.9 & 4.2 & 1.65 & 2 & 46.92 \\
\hline 48 & 9.31 & 8.31 & 2.42 & 1.24 & 1.54 & 22.82 \\
\hline 72 & 2.41 & 6.73 & 0.76 & 0.54 & 1.46 & 11.9 \\
\hline 96 & 0.85 & 6.18 & 0.04 & 0.04 & 1.41 & 8.50 \\
\hline 120 & 0.52 & 5.76 & 0 & 0 & 0.87 & 7.15 \\
\hline
\end{tabular}

Table C.4 Sugar consumption profile by strain S2

\begin{tabular}{|l|l|l|l|l|l|l|}
\hline $\begin{array}{l}\text { Time } \\
(\text { hours })\end{array}$ & $\begin{array}{l}\text { Glucose } \\
(\mathrm{g} / \mathrm{L})\end{array}$ & $\mathbf{X y l o s e}(\mathrm{g} / \mathbf{L})$ & $\begin{array}{l}\text { Arabinose } \\
(\mathrm{g} / \mathrm{L})\end{array}$ & $\begin{array}{l}\text { Mannose } \\
(\mathrm{g} / \mathbf{L})\end{array}$ & $\begin{array}{l}\text { Galactose } \\
(\mathrm{g} / \mathbf{L})\end{array}$ & $\begin{array}{l}\text { Total } \\
\text { sugars } \\
(\mathrm{g} / \mathrm{L})\end{array}$ \\
\hline 0 & 16 & 10 & 1.5 & 0.1 & 2.2 & 29.8 \\
\hline 24 & 27.1 & 13 & 4.6 & 1.67 & 2 & 48.37 \\
\hline 48 & 9.32 & 8.29 & 2.39 & 1.23 & 1.5 & 22.74 \\
\hline 72 & 2.38 & 6.73 & 0.66 & 0.47 & 1.39 & 11.63 \\
\hline 96 & 0.77 & 6.02 & 0.04 & 0.03 & 1.24 & 8.1 \\
\hline 120 & 0.52 & 5.71 & 0 & 0 & 0.88 & 7.11 \\
\hline
\end{tabular}


Table C.5 Sugar consumption profile by strain S3

\begin{tabular}{|l|l|l|l|l|l|l|}
\hline $\begin{array}{l}\text { Time } \\
(\text { hours })\end{array}$ & $\begin{array}{l}\text { Glucose } \\
(\mathrm{g} / \mathbf{L})\end{array}$ & $\begin{array}{l}\text { Xylose } \\
(\mathrm{g} / \mathrm{L})\end{array}$ & $\begin{array}{l}\text { Arabinose } \\
(\mathrm{g} / \mathrm{L})\end{array}$ & $\begin{array}{l}\text { Mannose } \\
(\mathrm{g} / \mathrm{L})\end{array}$ & $\begin{array}{l}\text { Galactose } \\
(\mathrm{g} / \mathrm{L})\end{array}$ & $\begin{array}{l}\text { Total } \\
\text { sugars } \\
(\mathrm{g} / \mathrm{L})\end{array}$ \\
\hline 0 & 16 & 10 & 1.5 & 0.1 & 2.2 & 29.8 \\
\hline 24 & 27 & 12.6 & 4.3 & 1.5 & 1.62 & 47.02 \\
\hline 48 & 9.3 & 8.33 & 2.4 & 1.23 & 1.55 & 22.82 \\
\hline 72 & 2.41 & 6.75 & 0.65 & 0.49 & 1.36 & 11.66 \\
\hline 96 & 0.77 & 6.02 & 0.04 & 0.03 & 1.24 & 8.1 \\
\hline 120 & 0.50 & 5.74 & 0.01 & 0 & 0.89 & 7.14 \\
\hline
\end{tabular}

Table C.6 Sugar consumption profile by strain S4

\begin{tabular}{|l|l|l|l|l|l|l|}
\hline $\begin{array}{l}\text { Time } \\
(\text { hours })\end{array}$ & $\begin{array}{l}\text { Glucose } \\
(\mathrm{g} / \mathrm{L})\end{array}$ & $\begin{array}{l}\text { Xylose } \\
(\mathrm{g} / \mathrm{L})\end{array}$ & $\begin{array}{l}\text { Arabinose } \\
(\mathrm{g} / \mathbf{L})\end{array}$ & $\begin{array}{l}\text { Mannose } \\
(\mathrm{g} / \mathbf{L})\end{array}$ & $\begin{array}{l}\text { Galactose } \\
(\mathrm{g} / \mathbf{L})\end{array}$ & $\begin{array}{l}\text { Total } \\
\text { sugars } \\
(\mathrm{g} / \mathbf{L})\end{array}$ \\
\hline 0 & 16 & 10 & 1.5 & 0.1 & 2.2 & 29.8 \\
\hline 24 & 26.4 & 14.2 & 4.29 & 1.36 & 1.58 & 46.83 \\
\hline 48 & 9.61 & 8.31 & 2.42 & 1.21 & 1.52 & 24.07 \\
\hline 72 & 2.44 & 6.73 & 0.86 & 0.47 & 1.39 & 11.89 \\
\hline 96 & 0.77 & 6.02 & 0.05 & 0.02 & 1.22 & 8.08 \\
\hline 120 & 0.52 & 5.74 & 0.02 & 0 & 1.02 & 7.3 \\
\hline
\end{tabular}


Table C.7 Sugar consumption profile by strain S5

\begin{tabular}{|l|l|l|l|l|l|l|}
\hline $\begin{array}{l}\text { Time } \\
(\text { hours })\end{array}$ & $\begin{array}{l}\text { Glucose } \\
(\mathbf{g} / \mathbf{L})\end{array}$ & $\begin{array}{l}\text { Xylose } \\
(\mathbf{g} / \mathbf{L})\end{array}$ & $\begin{array}{l}\text { Arabinose } \\
(\mathbf{g} / \mathbf{L})\end{array}$ & $\begin{array}{l}\text { Mannose } \\
(\mathbf{g} / \mathbf{L})\end{array}$ & $\begin{array}{l}\text { Galactose } \\
(\mathrm{g} / \mathbf{L})\end{array}$ & $\begin{array}{l}\text { Total } \\
\text { sugars } \\
(\mathbf{g} / \mathbf{L})\end{array}$ \\
\hline 0 & 16 & 10 & 1.5 & 0.1 & 2.2 & 29.8 \\
\hline 24 & 26.9 & 14.3 & 4.3 & 1.35 & 1.59 & 47.44 \\
\hline 48 & 9.52 & 8.3 & 2.39 & 1.22 & 1.53 & 22.96 \\
\hline 72 & 2.43 & 6.78 & 0.82 & 0.46 & 1.38 & 11.87 \\
\hline 96 & 0.81 & 6.09 & 0.06 & 0.04 & 1.24 & 8.24 \\
\hline 120 & 0.51 & 5.73 & 0.03 & 0.01 & 1.05 & 7.33 \\
\hline
\end{tabular}

Table C.8 Sugar consumption profile by strain S6

\begin{tabular}{|l|l|l|l|l|l|l|}
\hline $\begin{array}{l}\text { Time } \\
(\text { hours })\end{array}$ & Glucose(g/L) & $\begin{array}{l}\text { Xylose } \\
(\mathrm{g} / \mathbf{L})\end{array}$ & $\begin{array}{l}\text { Arabinose } \\
(\mathrm{g} / \mathbf{L})\end{array}$ & $\begin{array}{l}\text { Mannose } \\
(\mathrm{g} / \mathbf{L})\end{array}$ & $\begin{array}{l}\text { Galactose } \\
(\mathrm{g} / \mathbf{L})\end{array}$ & $\begin{array}{l}\text { Total } \\
\text { sugars } \\
(\mathrm{g} / \mathrm{L})\end{array}$ \\
\hline 0 & 16 & 10 & 1.5 & 0.1 & 2.2 & 29.8 \\
\hline 24 & 26.7 & 13 & 4.21 & 1.64 & 2.1 & 46.92 \\
\hline 48 & 9.29 & 8.32 & 2.43 & 1.34 & 1.55 & 22.82 \\
\hline 72 & 2.43 & 6.76 & 0.8 & 0.59 & 1.48 & 11.9 \\
\hline 96 & 0.87 & 6.2 & 0.04 & 0.04 & 1.42 & 8.5 \\
\hline 120 & 0.52 & 5.77 & 0.01 & 0.01 & 0.9 & 7.15 \\
\hline
\end{tabular}


Table C.9 Sugar Consumption profile by strain S7

\begin{tabular}{|l|l|l|l|l|l|l|}
\hline Time (hours) & Glucose (g/L) & $\begin{array}{l}\text { Xylose } \\
(\mathbf{g} / \mathbf{L})\end{array}$ & $\begin{array}{l}\text { Arabinose } \\
(\mathbf{g} / \mathbf{L})\end{array}$ & $\begin{array}{l}\text { Mannose } \\
(\mathrm{g} / \mathbf{L})\end{array}$ & $\begin{array}{l}\text { Galactose } \\
(\mathrm{g} / \mathbf{L})\end{array}$ & $\begin{array}{l}\text { Total sugars } \\
(\mathrm{g} / \mathbf{L})\end{array}$ \\
\hline 0 & 16 & 10 & 1.5 & 0.1 & 2.2 & 29.8 \\
\hline 24 & 25.9 & 12.9 & 4.19 & 1.4 & 1.59 & 45.98 \\
\hline 48 & 9.3 & 8.34 & 2.4 & 1.25 & 1.56 & 22.85 \\
\hline 72 & 2.7 & 6.77 & 0.85 & 0.59 & 1.47 & 12.38 \\
\hline 96 & 0.83 & 6.11 & 0.05 & 0.05 & 1.27 & 8.31 \\
\hline 120 & 0.53 & 5.91 & 0.02 & 0.01 & 1.04 & 7.51 \\
\hline
\end{tabular}

Table C.10 Total sugars consumed by different strains of bacteria over 120 hours

\begin{tabular}{|c|c|c|}
\hline Strain & Total Sugar Consumed (g/L) & $\begin{array}{c}\text { \% age } \\
\text { conversion }\end{array}$ \\
\hline S1 & 39.77 & 84.76 \\
\hline S2 & 41.26 & 85.4 \\
\hline S3 & 39.88 & 84.82 \\
\hline S4 & 39.53 & 84.4 \\
\hline S5 & 40.11 & 84.54 \\
\hline S6 & 39.77 & 84.7 \\
\hline S7 & 38.47 & 84.6 \\
\hline
\end{tabular}


Table C.11 Individual and total sugar yields in w/w percentage for algal biomass samples

\begin{tabular}{|l|l|l|l|l|l|l|}
\hline Sample & $\begin{array}{l}\text { Glucose } \\
\mathbf{\%}\end{array}$ & Galactose\% & Mannose\% & Arabinose\% & Xylose\% & $\begin{array}{l}\text { Total } \\
\text { Sugar } \\
\%\end{array}$ \\
\hline Algae 1 & 10.8 & 2.3 & 5.1 & 3 & 7 & 28.2 \\
\hline Algae 2 & 10.2 & 2.1 & 4.8 & 4.1 & 7.4 & 27.6 \\
\hline Algae 3 & 11.1 & 2.1 & 4.7 & 4.5 & 7.1 & 28.5 \\
\hline Algae 4 & 11.7 & 2.1 & 4.7 & 4.4 & 7.2 & 29.1 \\
\hline Algae 5 & 8.9 & 2 & 4.6 & 4.7 & 7.1 & 26.3 \\
\hline Algae 6 & 10.3 & 2.1 & 4.5 & 4.3 & 7.5 & 27.7 \\
\hline Algae 7 & 10 & 2.2 & 4.5 & 4.1 & 7.6 & 27.4 \\
\hline Algae 8 & 15.6 & 2 & 4.6 & 2.6 & 8.2 & 34.0 \\
\hline Algae 9 & 15.2 & 2.3 & 4.4 & 2.7 & 8 & 32.6 \\
\hline Algae 10 & 12.5 & 2.3 & 4.9 & 2.9 & 7.8 & 30.4 \\
\hline Algae 11 & 12.7 & 2.2 & 4.7 & 4.2 & 7.8 & 30.6 \\
\hline Algae 12 & 14 & 2.1 & 4.1 & 2.2 & 8.5 & 30.9 \\
\hline Algae 13 & 14.2 & 2.1 & 4 & 2.4 & 8.4 & 31.1 \\
\hline
\end{tabular}

Table C.12 WS vs Algae sugar yields

\begin{tabular}{|l|l|l|l|l|l|l|}
\hline Feedstock & $\begin{array}{l}\text { Glucose } \\
(\mathbf{w} / \mathbf{w})\end{array}$ & $\begin{array}{l}\text { Xylose } \\
(\mathbf{w} / \mathbf{w})\end{array}$ & $\begin{array}{l}\text { Arabinose } \\
(\mathbf{w} / \mathbf{w})\end{array}$ & $\begin{array}{l}\text { Mannose } \\
(\mathbf{w} / \mathbf{w})\end{array}$ & $\begin{array}{l}\text { Galactose } \\
(\mathbf{w} / \mathbf{w})\end{array}$ & $\begin{array}{l}\text { Total } \\
\text { Sugar } \\
(\mathbf{w} / \mathbf{w})\end{array}$ \\
\hline $\mathrm{WSH}$ & 0.32 & 0.24 & 0.063 & 0.027 & 0.03 & 0.69 \\
\hline $\mathrm{AH}$ & 0.156 & 0.2 & .046 & .026 & .0082 & 0.33 \\
\hline
\end{tabular}


Table C.13 ABE yield for different pre-treated samples of algal biomass after 120 hours of SSF

\begin{tabular}{|c|c|c|c|c|}
\hline $\begin{array}{l}\text { Algal } \\
\text { biomass } \\
\text { sample }\end{array}$ & $\begin{array}{l}\text { ABE } \\
\text { yield }\end{array}$ & Acetone yield & Biobutanol yield & Ethanol yield \\
\hline A1 & 0.465 & 0.131 & 0.291 & 0.042 \\
\hline A2 & 0.483 & 0.143 & 0.292 & 0.047 \\
\hline A3 & 0.473 & 0.140 & 0.281 & 0.051 \\
\hline A4 & 0.484 & 0.144 & 0.296 & 0.044 \\
\hline
\end{tabular}




\section{Appendix D Error calculation for SSF study raw data}

Strain S1: Non- mutated, parent $C b C t$ strain

Table D.1 Total sugar concentration profiles for strain S1 for three SSF experiments

\begin{tabular}{|c|c|c|c|c|c|c|}
\hline \multirow{2}{*}{ Time (hour) } & \multicolumn{3}{|c|}{ Total sugars (g/L) } & \multirow{2}{*}{ Avg } & \multirow{2}{*}{ std dev } & \% rsd \\
\cline { 2 - 5 } & $\# 1$ & $\# 2$ & $\# 3$ & & & \\
\hline 0 & 29.8 & 29.5 & 29.7 & 29.7 & 0.124 & 0.420 \\
\hline 24 & 46.92 & 46.8 & 47 & 46.90 & 0.082 & 0.175 \\
\hline 48 & 22.82 & 22.5 & 22.6 & 22.64 & 0.133 & 0.590 \\
\hline 72 & 11.9 & 12 & 11.8 & 11.9 & 0.081 & 0.686 \\
\hline 76 & 8.5 & 8.5 & 8.3 & 8.43 & 0.094 & 1.117 \\
\hline 120 & 7.15 & 7.2 & 7.1 & 7.15 & 0.040 & 0.570 \\
\hline
\end{tabular}

\section{Strain S2: UV 10 min}

Table D.2 Total sugar profile for strain S2 over three SSF experiments

\begin{tabular}{|c|c|c|c|c|c|c|}
\hline \multirow{2}{*}{$\begin{array}{l}\text { Time } \\
\text { (hour) }\end{array}$} & \multicolumn{3}{|c|}{ Total sugars $(g / L)$} & \multirow{2}{*}{ Avg } & \multirow{2}{*}{ std dev } & \multirow{2}{*}{ \% rsd } \\
\hline & $\# 1$ & $\# 2$ & $\# \mathbf{3}$ & & & \\
\hline 0 & 29.8 & 29.5 & 29.7 & 29.667 & 0.124 & 0.420 \\
\hline 24 & 48.37 & 48.2 & 48.35 & 48.306 & 0.075 & 0.157 \\
\hline 48 & 22.74 & 22.73 & 22.77 & 22.746 & 0.016 & 0.074 \\
\hline 72 & 11.63 & 11.58 & 11.6 & 11.603 & 0.020 & 0.177 \\
\hline 96 & 8.1 & 8.03 & 8.09 & 8.0733 & 0.030 & 0.382 \\
\hline 120 & 7.11 & 7.1 & 7.11 & 7.1066 & 0.004 & 0.066 \\
\hline
\end{tabular}


Strain S3: UV 15 min

Table D.3 Sugar profile for strain S3 over three SSF experiments

\begin{tabular}{|c|c|c|c|c|c|c|}
\hline \multirow{2}{*}{$\begin{array}{l}\text { Time } \\
\text { (hour) }\end{array}$} & \multicolumn{3}{|c|}{ Total sugars $(\mathrm{g} / \mathrm{L})$} & \multirow{2}{*}{ Avg } & \multirow{2}{*}{ std dev } & \multirow{2}{*}{$\%$ rsd } \\
\hline & $\# 1$ & $\# 2$ & $\# \mathbf{3}$ & & & \\
\hline 0 & 29.8 & 29.5 & 29.7 & 29.667 & 0.124 & 0.420 \\
\hline 24 & 47.02 & 47 & 47 & 47.007 & 0.009 & 0.0200 \\
\hline 48 & 22.82 & 22.8 & 22.7 & 22.773 & 0.052 & 0.230 \\
\hline 72 & 11.66 & 11.6 & 11.5 & 11.586 & 0.065 & 0.569 \\
\hline 96 & 8.1 & 8 & 8.1 & 8.066 & 0.047 & 0.584 \\
\hline 120 & 7.14 & 7.15 & 7.1 & 7.13 & 0.021 & 0.302 \\
\hline
\end{tabular}

Strain S4: EMS 20 min

Table D. Sugar profile for strain S4 over three SSF experiments

\begin{tabular}{|c|c|c|c|c|c|c|}
\hline \multirow{2}{*}{$\begin{array}{l}\text { Time } \\
\text { (hour) }\end{array}$} & \multicolumn{3}{|c|}{ Total sugars (g/L) } & \multirow{2}{*}{ Avg } & \multirow{2}{*}{ std dev } & \multirow{2}{*}{ \% rsd } \\
\cline { 2 - 7 } & $\# 1$ & $\# 2$ & $\# 3$ & & \\
\hline 0 & 29.8 & 29.5 & 29.7 & 29.667 & 0.124 & 0.42 \\
\hline 24 & 46.83 & 46.82 & 46.8 & 46.817 & 0.0124 & 0.026 \\
\hline 48 & 23.07 & 23 & 23 & 23.023 & 0.032 & 0.143 \\
\hline 72 & 11.89 & 11.9 & 11.85 & 11.88 & 0.021 & 0.181 \\
\hline 96 & 8.08 & 8.05 & 8.05 & 8.06 & 0.014 & 0.175 \\
\hline 120 & 7.3 & 7.28 & 7.25 & 7.277 & 0.021 & 0.283 \\
\hline
\end{tabular}


Strain S5: EMS 40 min

Table D.5 Sugar profile for strain S5 over three SSF experiments

\begin{tabular}{|c|c|c|c|c|c|c|}
\hline \multirow{2}{*}{$\begin{array}{c}\text { Time } \\
\text { (hour) }\end{array}$} & \multicolumn{3}{|c|}{ Total sugars (g/L) } & \multirow{2}{*}{ Avg } & \multirow{2}{*}{ std dev } & \multirow{2}{*}{ \% rsd } \\
\cline { 2 - 6 } & $\# 1$ & $\# 2$ & $\# 3$ & & & \\
\hline 0 & 29.8 & 29.5 & 29.7 & 29.667 & 0.124 & 0.420 \\
\hline 24 & 47.44 & 47.45 & 47.4 & 47.43 & 0.021 & 0.045 \\
\hline 48 & 22.96 & 22.95 & 22.9 & 22.937 & 0.026 & 0.114 \\
\hline 72 & 11.87 & 11.87 & 11.85 & 11.863 & 0.009 & 0.079 \\
\hline 96 & 8.24 & 8.2 & 8.23 & 8.223 & 0.017 & 0.207 \\
\hline 120 & 7.33 & 7.29 & 7.25 & 7.29 & 0.032 & 0.448 \\
\hline
\end{tabular}

Strain S6: EMS $50 \mathrm{~min}$

Table D.6 Sugar profile for strain S6 over three SSF experiments

\begin{tabular}{|c|c|l|l|l|l|l|}
\hline \multirow{2}{*}{$\begin{array}{c}\text { Time } \\
\text { (hour) }\end{array}$} & \multicolumn{3}{|c|}{ Total sugars (g/L) } & \multirow{2}{*}{ Avg } & \multirow{2}{*}{ std dev } & \% rsd \\
\cline { 2 - 7 } & $\# \mathbf{1}$ & \#2 & \#3 & & & \\
\hline 0 & 29.8 & 29.5 & 29.7 & 29.667 & 0.125 & 0.42 \\
\hline 24 & 46.92 & 46.9 & 46.9 & 46.906 & 0.009 & 0.02 \\
\hline 48 & 22.82 & 22.82 & 22.83 & 22.823 & 0.004 & 0.020 \\
\hline 72 & 11.9 & 11.85 & 11.9 & 11.883 & 0.023 & 0.198 \\
\hline 96 & 8.5 & 8.46 & 8.45 & 8.47 & 0.021 & 0.255 \\
\hline 120 & 7.15 & 7.11 & 7.14 & 7.133 & 0.016 & 0.238 \\
\hline
\end{tabular}




\section{Strain S7: EMS 60 min}

Table D.7 Sugar profile for strain S7 over three SSF experiments

\begin{tabular}{|c|c|c|c|c|c|c|}
\hline \multirow{2}{*}{$\begin{array}{l}\text { Time } \\
\text { (hour) }\end{array}$} & \multicolumn{3}{|c|}{ Total sugars $(\mathrm{g} / \mathrm{L})$} & \multirow{2}{*}{ Avg } & \multirow{2}{*}{ std dev } & \multirow{2}{*}{ \% rsd } \\
\hline & $\# 1$ & \#2 & \#3 & & & \\
\hline 0 & 29.8 & 29.5 & 29.7 & 29.667 & 0.124 & 0.420 \\
\hline 24 & 45.98 & 45.96 & 45.95 & 45.963 & 0.012 & 0.027 \\
\hline 48 & 22.85 & 22.8 & 22.76 & 22.803 & 0.036 & 0.161 \\
\hline 72 & 12.38 & 12.35 & 12.34 & 12.356 & 0.017 & 0.137 \\
\hline 96 & 8.31 & 8.25 & 8.27 & 8.2766 & 0.025 & 0.301 \\
\hline 120 & 7.51 & 7.52 & 7.48 & 7.503 & 0.017 & 0.226 \\
\hline
\end{tabular}




\section{Appendix E Error calculation for Algal Bio-refinery study}

Table E.1 Total sugar concentration for all samples over three hydrolysis experiments with algal biomass as feedstock

\begin{tabular}{|l|c|c|l|l|l|l|}
\hline \multirow{2}{*}{ Sample } & \multicolumn{3}{|c|}{ Total Sugar (g/l) } & \multirow{2}{*}{ Avg } & \multirow{2}{*}{ Std dev } & \% rsd \\
\cline { 2 - 6 } & $\# 1$ & $\# 2$ & $\# 3$ & & & \\
\hline S1 & 22.56 & 22.55 & 22.5 & 22.537 & 0.026 & 0.117 \\
\hline S2 & 22.08 & 22 & 22.1 & 22.06 & 0.043 & 0.196 \\
\hline S3 & 22.8 & 22.77 & 22.8 & 22.79 & 0.014 & 0.062 \\
\hline S4 & 23.28 & 23.3 & 22.25 & 22.943 & 0.490 & 2.137 \\
\hline S5 & 21.04 & 21 & 20.9 & 20.98 & 0.059 & 0.281 \\
\hline S6 & 22.16 & 22.15 & 22.12 & 22.143 & 0.017 & 0.077 \\
\hline S7 & 21.92 & 21.9 & 21.83 & 21.883 & 0.039 & 0.176 \\
\hline S8 & 26.4 & 26.33 & 26.34 & 26.357 & 0.031 & 0.117 \\
\hline S9 & 26.08 & 26.1 & 26 & 26.06 & 0.043 & 0.166 \\
\hline S10 & 24.32 & 24.32 & 24.3 & 24.313 & 0.009 & 0.0388 \\
\hline S11 & 24.48 & 24.47 & 23.45 & 24.133 & 0.483 & 2.002 \\
\hline S12 & 24.72 & 24.7 & 24.59 & 24.67 & 0.057 & 0.232 \\
\hline S13 & 24.88 & 24.85 & 24.83 & 24.853 & 0.021 & 0.083 \\
\hline
\end{tabular}


Table E.2 Biobutanol concentration profile for all samples at $120 \mathrm{hr}$ over three SSF experiments with algal biomass as feedstock

\begin{tabular}{|l|c|c|c|c|c|c|}
\hline \multirow{2}{*}{ Sample } & \multicolumn{3}{|c|}{ Biobutanol (g/L) } & \multirow{2}{*}{} & & \multirow{2}{*}{ \#1 } \\
\cline { 2 - 5 } & $\# \mathbf{2}$ & $\mathbf{\# 3}$ & \multirow{2}{*}{ Avg } & Std dev & \% rsd \\
\hline S1 & 6.2 & 6.1 & 6.05 & 6.117 & 0.062 & 1.020 \\
\hline S2 & 7.52 & 7.5 & 7.48 & 7.5 & 0.016 & 0.218 \\
\hline S3 & 7.3 & 7.25 & 7.23 & 7.26 & 0.029 & 0.405 \\
\hline S4 & 7.2 & 7.1 & 7.11 & 7.137 & 0.045 & 0.630 \\
\hline
\end{tabular}




\section{REFERENCES}

Awad, N. E. (2000, December). Phytotherapy Research. Biologically active steroid from the green alga Ulva lactuca., 14(8), 641-643.

Awang, G. M., Jones, G. A., Ingledew, W. M., \& Kropinski, A. M. B. (1988). The acetone-biobutanolethanol fermentation. Critical reviews in microbiology, 15(S1), S33-S67.

Balat, M., \& Balat, H. (2009). Recent trends in global production and utilization of bio-ethanol fuel. Applied Energy, 86(11), 2273-2282.

Banerjee, A., Sharma, R., Chisti, Y., \& Banerjee, U. C. (2002). Botryococcus braunii: a renewable source of hydrocarbons and other chemicals. Critical reviews in biotechnology, 22(3), 245-279.

Baronofsky, J. J., Schreurs, W. J., \& Kashket, E. R. (1984). Uncoupling by acetic acid limits growth of and acetogenesis by Clostridium thermoaceticum.Applied and environmental microbiology, 48(6), 1134-1139.

Beal, C. M., Hebner, R. E., Webber, M. E., Ruoff, R. S., \& Seibert, A. F. (2012). The energy return on investment for algal biocrude: results for a research production facility. BioEnergy Research, 5(2), 341362.

Benemann, J. R. (2008). Overview: Algae oil to biofuels. In NREL-AFOSR Workshop," Algal Oil for Jet Fuel Production.

Bjerre, A. B., Olesen, A. B., Fernqvist, T., Plöger, A., \& Schmidt, A. S. (1996). Pretreatment of wheat straw using combined wet oxidation and alkaline hydrolysis resulting in convertible cellulose and hemicellulose. Biotechnology and bioengineering, 49(5), 568-577.

Bowring, Sarah N., and J. G. Morris. "Mutagenesis of Clostridium acetobutylicum." Journal of Applied Microbiology 58.6 (1985): 577-584.

Brennan, L., \& Owende, P. (2010). Biofuels from microalgae - a review of technologies for production, processing, and extractions of biofuels and co-products. Renewable and sustainable energy reviews, 14(2), 557-577.

Brigham, J. S., Adney, W. S., and Himmel, M. E. (1996), in Handbook on Bioethanol: Production and Utilization, Wyman, C., ed., Taylor and Francis, Washington, DC, pp. 119--141.

Brioukhanov, A. L., \& Netrusov, A. I. (2004). Catalase and superoxide dismutase: distribution, properties, and physiological role in cells of strict anaerobes. Biochemistry (Moscow), 69(9), 949-962.

Brune, D. E., Lundquist, T. J., \& Benemann, J. R. (2009). Microalgal biomass for greenhouse gas reductions: potential for replacement of fossil fuels and animal feeds. Journal of Environmental Engineering, 135(11), 1136-1144. 
Buday, Z., Linden, J. C., \& Karim, M. N. (1990). Improved acetone-biobutanol fermentation analysis using subambient HPLC column temperature. Enzyme and microbial technology, 12(1), 24-27.

Burton T., L. H. (2009). Sustainable Energy Ireland. 1-88. Ireland.

Bush, R. A., \& Hall, K. M. (2006). U.S. Patent No. 7,135,308. Washington, DC: U.S. Patent and Trademark Office.

Cardona, C. A., \& Sánchez, Ó. J. (2007). Fuel ethanol production: process design trends and integration opportunities. Bioresource technology, 98(12), 2415-2457.

Carere, C. R., Sparling, R., Cicek, N., \& Levin, D. B. (2008). Third generation biofuels via direct cellulose fermentation. International journal of molecular sciences, 9(7), 1342-1360.

Chang, J. C., Ossoff, S. F., Lobe, D. C., Dorfman, M. H., Dumais, C. M., Qualls, R. G., \& Johnson, J. D. (1985). UV inactivation of pathogenic and indicator microorganisms. Applied and Environmental Microbiology, 49(6), 1361-1365.

Chisti, Y. (2007). Biodiesel from microalgae. Biotechnology advances, 25(3), 294-306.

Christenson, L., \& Sims, R. (2011). Production and harvesting of microalgae for wastewater treatment, biofuels, and bioproducts. Biotechnology advances, 29(6), 686-702.

Cleveland CJ (2005) Net energy from the extraction of oil and gas in the United States. Energy 30:769-782

Costa, J. M., \& Moreira, A. R. (1983). Growth inhibition kinetics for the acetone-biobutanol fermentation. In ACS Symposium Series[ACS SYMP. SER.]. 1983..

Coyle, W. (2007). The future of biofuels. Economic Research Service, Washington, DC.

Dahman, Y., Jayasuriya, K.E., and Kalis, M. (2010). Potential of Biocellulose Nanofibers Production from Agricultural Renewable Resources: Preliminary Study. Applied Biochemistry and Biotechnology. $162,1647-1659$.

David, K., \& Ragauskas, A. J. (2010). Switchgrass as an energy crop for biofuel production: A review of its ligno-cellulosic chemical properties. Energy \& Environmental Science, 3(9), 1182-1190.

Demirbas, A., \& Fatih Demirbas, M. (2011). Importance of algae oil as a source of biodiesel. Energy Conversion and Management, 52(1), 163-170.

Dewsbury, P., Thornton, S. F., \& Lerner, D. N. (2003). Improved analysis of MTBE, TAME, and TBA in petroleum fuel-contaminated groundwater by SPME using deuterated internal standards with GC- 
MS. Environmental science \& technology, 37(7), 1392-1397.

Dismukes, G. C., Carrieri, D., Bennette, N., Ananyev, G. M., \& Posewitz, M. C. (2008). Aquatic phototrophs: efficient alternatives to land-based crops for biofuels. Current Opinion in Biotechnology, 19(3), 235-240.

Domínguez, M. C., de la Rosa, M., \& Borobio, M. V. (2001). Application of a spectrophotometric method for the determination of post-antibiotic effect and comparison with viable counts in agar. Journal of Antimicrobial Chemotherapy, 47(4), 391-398.

Doucha, J., Straka, F., \& Lívanský, K. (2005). Utilization of flue gas for cultivation of microalgae Chlorella sp.) in an outdoor open thin-layer photobioreactor. Journal of Applied Phycology, 17(5), 403412.

Dürre, P. (1998). New insights and novel developments in clostridial acetone/biobutanol/isopropanol fermentation. Applied Microbiology and Biotechnology. 49, 639-648.

Dürre, P. (2007). Biobutanol: an attractive biofuel. Biotechnol J. 2, 1525-1534

El Kanouni, A., Zerdani, I., Zaafa, S., Znassni, M., Loutfi, M., \& Boudouma, M. (1998). The improvement of glucose/xylose fermentation by Clostridium acetobutylicum using calcium carbonate. World Journal of Microbiology and Biotechnology, 14(3), 431-435.

Ellis, J. T., Hengge, N. N., Sims, R. C., \& Miller, C. D. (2012). Acetone, biobutanol, and ethanol production from wastewater algae. Bioresource technology, 111, 491-495.

Ezeji, T., Milne, C., Price, N.D., and Blaschek, H.P. (2010). Achievements and perspectives to overcome the poor solvent resistance in acetone and biobutanol-producing microorganisms. Appl. Microbiol. Biotechnol. 85, 1697-1712.

Ezeji, T., Qureshi, N., \& Blaschek, H. P. (2007). Production of acetone-biobutanol-ethanol (ABE) in a continuous flow bioreactor using degermed corn and Clostridium beijerinckii. Process Biochemistry, 42(1), 34-39.

Farrell AE, Plevin RJ, Turner BT, Jones AD, O'Hare M, Kammen DM (2006) Ethanol can contribute to energy and environmental goals. Science 311:506-508

Fond, O., Engasser, J. M., Matta-El-Amouri, G., \& Petitdemange, H. (1986). The acetone biobutanol fermentation on glucose and xylose. I. Regulation and kinetics in batch cultures. Biotechnology and bioengineering, 28(2), 160-166

Food and Agriculture Organisation, United Nations. (2009). Algae-based bioenergy options. 
Formanek, J., Mackie, R., \& Blaschek, H. P. (1997). Enhanced Biobutanol Production by Clostridium beijerinckii BA101 Grown in Semidefined P2 Medium Containing 6 Percent Maltodextrin or Glucose. Applied and environmental microbiology, 63(6), 2306-2310.

Friedberg, E. C., Walker, G. C., \& Siede, W. (1995). DNA repair and mutagenesis. American Society for Microbiology (ASM).

Fu, C., Mielenz, J. R., Xiao, X., Ge, Y., Hamilton, C. Y., Rodriguez, M. \& Wang, Z. Y. (2011). Genetic manipulation of lignin reduces recalcitrance and improves ethanol production from switchgrass. Proceedings of the National Academy of Sciences, 108(9), 3803-3808.

Gamal, A. A. (2010, January). Saudi Pharmaceutical Journal. Biological importance of marine algae., $18(1), 1-25$.

Ge, Y., Liu, J., \& Tian, G. (2011). Growth characteristics of $<\mathrm{i}>$ Botryococcus braunii $</ \mathrm{i}>765$ under high $\mathrm{CO}<\mathrm{sub}>2</$ sub $>$ concentration in photobioreactor. Bioresource technology, 102(1), 130-134.

Goering, H. K., \& Van Soest, P. J. (1970). Forage fiber analyses (apparatus, reagents, procedures, and some applications). USDA Agr Handb.

Gokhale, D. V., Puntambekar, U. S., \& Deobagkar, D. N. (1993). Protoplast fusion: a tool for intergeneric gene transfer in bacteria. Biotechnology advances, 11(2), 199-217.

Hahn-Hägerdal, B., Galbe, M., Gorwa-Grauslund, M. F., Liden, G., \& Zacchi, G. (2006). Bio-ethanolthe fuel of tomorrow from the residues of today. Trends in biotechnology, 24(12), 549-556.

Harper, S. H., \& Lynch, J. M. (1981). The chemical components and decomposition of wheat straw leaves, internodes and nodes. Journal of the Science of Food and Agriculture, 32(11), 1057-1062.

Harun, R., \& Danquah, M. K. (2011). Influence of acid pre-treatment on microalgal biomass for bioethanol production. Process Biochemistry, 46(1), 304-309.

Helgeson, J. P., Hunt, G. J., Haberlach, G. T., \& Austin, S. (1986). Somatic hybrids between Solanum brevidens and Solanum tuberosum: Expression of a late blight resistance gene and potato leaf roll resistance. Plant Cell Reports, 5(3), 212-214.

Hillmann, F., Fischer, R. J., Saint-Prix, F., Girbal, L., \& Bahl, H. (2008). PerR acts as a switch for oxygen tolerance in the strict anaerobe Clostridium acetobutylicum. Molecular microbiology, 68(4), 848-860.

Ikehata, H., \& Ono, T. (2011). The mechanisms of UV mutagenesis. Journal of radiation research, 52(2), 115-125. 
Jacobsen, S. E., \& Wyman, C. E. (2000). Cellulose and hemicellulose hydrolysis models for application to current and novel pretreatment processes. In Twenty-First Symposium on Biotechnology for Fuels and Chemicals (pp. 81-96). Humana Press.

Jae Sue Choi, H. J. (2000). Journal of Natural Products. A cyclohexanonyl bromophenol from the red alga Symphyocladia latiuscula., 63(12), 1705-1706.

Jang, Y. S., Malaviya, A., Cho, C., Lee, J., \& Lee, S. Y. (2012). Butanol production from renewable biomass by clostridia. Bioresource technology, 123, 653-663.

Johnson, M. B. (2009). Microalgal Biodiesel Production through a Novel Attached Culture System and Conversion Parameters.

Jones, D. T., \& Woods, D. R. (1986). Acetone-biobutanol fermentation revisited. Microbiological reviews, 50(4), 484.

Kádár, Z., Szengyel, Z., \& Réczey, K. (2004). Simultaneous saccharification and fermentation (SSF) of industrial wastes for the production of ethanol. Industrial Crops and Products, 20(1), 103-110.

Kagan, J. (2010). Third and Fourth Generation Biofuels: Technologies, Markets and Economics Through 2015.

Kao, K. N., \& Michayluk, M. (1974). A method for high-frequency intergeneric fusion of plant protoplasts. Planta, 115(4), 355-367.

Kato, S., Haruta, S., Cui, Z. J., Ishii, M., Yokota, A., \& Igarashi, Y. (2004). Clostridium straminisolvens sp. nov., a moderately thermophilic, aerotolerant and cellulolytic bacterium isolated from a cellulose-degrading bacterial community. International journal of systematic and evolutionary microbiology, 54(6), 2043-2047.

Kenyon, C. J. (1983). The bacterial response to DNA damage. Trends in Biochemical Sciences, 8(3), 84-87.

Khan, S. A., Hussain, M. Z., Prasad, S., \& Banerjee, U. C. (2009). Prospects of biodiesel production from microalgae in India. Renewable and Sustainable Energy Reviews, 13(9), 2361-2372.

Kubiszewski I, Cleveland CJ, Endres PK (2010) Meta-analysis of net energy return for wind power systems. Renewable Energy 35:218-225

Kumar, A., Cameron, J. B., \& Flynn, P. C. (2005). Pipeline transport and simultaneous saccharification of corn stover. Bioresource technology, 96(7), 819-829.

Kumar, P., Barrett, D. M., Delwiche, M. J., \& Stroeve, P. (2009). Methods for pretreatment of lignocellulosic biomass for efficient hydrolysis and biofuel production. Industrial \& Engineering Chemistry Research, 48(8), 3713-3729. 
Kim, J. W., Park, J. C., Cho, H. Y., \& Kim, J. S. (2013). U.S. Patent No. 8,546,116. Washington, DC: U.S. Patent and Trademark Office.

Ladisch, M. R., \& Svarczkopf, J. A. (1991). Ethanol production and the cost of fermentable sugars from biomass. Bioresource technology, 36(1), 83-95.

Lee, S. K., Chou, H., Ham, T. S., Lee, T. S., \& Keasling, J. D. (2008). Metabolic engineering of microorganisms for biofuels production: from bugs to synthetic biology to fuels. Current opinion in biotechnology, 19(6), 556-563.

Lee, R. A., \& Lavoie, J. M. (2013). From first-to third-generation biofuels: Challenges of producing a commodity from a biomass of increasing complexity. Animal Frontiers, 3(2), 6-11.

Leung, J. C. Y., \& Wang, D. I. C. (1981). Production of acetone and biobutanol by Clostridium acetobutylicum in continuous culture using free cells and immobilized cells. Proc 2nd World Congr Chem Eng, 1, 348-352.

Liu, S., \& Qureshi, N. (2009). How microbes tolerate ethanol and biobutanol. New biotechnology, 26(3), 117-121.

Lü, J., Sheahan, C., \& Fu, P. (2011). Metabolic engineering of algae for fourth generation biofuels production. Energy \& Environmental Science, 4(7), 2451-2466.

Lütke-Eversloh, T., \& Bahl, H. (2011). Metabolic engineering of $<\mathrm{i}>$ Clostridium acetobutylicum $<\mathrm{i}>$ : recent advances to improve butanol production. Current opinion in biotechnology, 22(5), 634-647.

Lumppio, H. L., Shenvi, N. V., Summers, A. O., Voordouw, G., \& Kurtz, D. M. (2001). Rubrerythrin and Rubredoxin Oxidoreductase inDesulfovibrio vulgaris: a Novel Oxidative Stress Protection System. Journal of bacteriology, 183(1), 101-108.

Lundquist, T. J., Woertz, I. C., Quinn, N. W. T., \& Benemann, J. R. (2010). A realistic technology and engineering assessment of algae biofuel production. Energy Biosciences Institute, 1.

Luque, R., Campelo, J., \& Clark, J. (Eds.). (2010). Handbook of biofuels production: processes and technologies. Elsevier.

Lynd, L. R., Van Zyl, W. H., McBride, J. E., \& Laser, M. (2005). Consolidated bioprocessing of cellulosic biomass: an update. Current opinion in biotechnology, 16(5), 577-583.

May, A., Hillmann, F., Riebe, O., Fischer, R. J., \& Bahl, H. (2004). A rubrerythrin-like oxidative stress protein of Clostridium acetobutylicum is encoded by a duplicated gene and identical to the heat shock protein Hsp21.FEMS microbiology letters, 238(1), 249-254.

McMillan, J. D., Newman, M. M., Templeton, D. W., \& Mohagheghi, A. (1999). Simultaneous saccharification and cofermentation of dilute-acid pretreated yellow poplar hardwood to ethanol using 
xylose-fermenting Zymomonas mobilis. In Twentieth Symposium on Biotechnology for Fuels and Chemicals (pp. 649-665). Humana Press.

Melis, A., \& Happe, T. (2001). Hydrogen production. Green algae as a source of energy. Plant physiology, 127(3), 740-748.

Morgera, E., Kulovesi, K., \& Gobena, A. (2009). Case studies on bioenergy policy and law: options for sustainability. FAO Legislative Study, (102).

Mosier, N., Wyman, C., Dale, B., Elander, R., Lee, Y. Y., Holtzapple, M., \& Ladisch, M. (2005). Features of promising technologies for pretreatment of lignocellulosic biomass. Bioresource technology, 96(6), 673-686.

Mukhopadhyay, K., \& Thomassin, P. J. (2011). Macroeconomic effects of the ethanol biofuel sector in Canada. Biomass and Bioenergy, 35(7), 2822-2838.

Nigam, P. S., \& Singh, A. (2011). Production of liquid biofuels from renewable resources. Progress in Energy and Combustion Science, 37(1), 52-68.

Nguyen, M. T., Choi, S. P., Lee, J., Lee, J. H., \& Sim, S. J. (2009). Hydrothermal acid pretreatment of Chlamydomonas reinhardtii biomass for ethanol production. Journal of microbiology and biotechnology, 19(2), 161-166.

Nochur, S. V., Roberts, M. F., \& Demain, A. L. (1990). Mutation of Clostridium thermocellum in the presence of certain carbon sources. FEMS Microbiology Letters, 71(1), 199-204.

O’Connor, D. (2011). Biodiesel GHG emissions, past, present, and future.

Olofsson, K., Bertilsson, M., \& Lidén, G. (2008). A short review on SSF-an interesting process option for ethanol production from lignocellulosic feedstocks. Biotechnol Biofuels, 1(7), 1-14.

Olson, D. G., McBride, J. E., Joe Shaw, A., \& Lynd, L. R. (2012). Recent progress in consolidated bioprocessing. Current opinion in biotechnology, 23(3), 396-405.

Ounine, K., Petitdemange, H., Raval, G., \& Gay, R. (1985). Regulation and butanol inhibition of Dxylose and D-glucose uptake in Clostridium acetobutylicum. Applied and environmental microbiology, 49(4), 874-878.

Pabbi, S., Dhar, D. W., Bhatnagar, S. K., Saxena, A., \& Kraan, S. (2011). Feasibility of algal biomass for biodiesel production. Algae biofuel, 268-288.

Philippidis, G. P., Smith, T. K., \& Wyman, C. E. (1993). Study of the enzymatic hydrolysis of cellulose for production of fuel ethanol by the simultaneous saccharification and fermentation process. Biotechnology and Bioengineering, 41(9), 846-853. 
Pienkos, P. T., \& Darzins, A. L. (2009). The promise and challenges of microalgal-derived biofuels. Biofuels, Bioproducts and Biorefining, 3(4), 431-440.

Pittman, J. K., Dean, A. P., \& Osundeko, O. (2011). The potential of sustainable algal biofuel production using wastewater resources. Bioresource Technology, 102(1), 17-25.

Potts, T., Du, J., Paul, M., May, P., Beitle, R., \& Hestekin, J. (2012). The production of biobutanol from Jamaica bay macro algae. Environmental Progress \& Sustainable Energy, 31(1), 29-36.

Qing, Q., Yang, B., \& Wyman, C. E. (2010). Xylooligomers are strong inhibitors of cellulose hydrolysis by enzymes. Bioresource technology, 101(24), 9624-9630.

Qurat-ul-Ain Syed, Nadeem M., Nelofer R.(2008). Enhanced biobutanol production by mutant strains of Clostridium acetobutylicum in molasses medium. Türk Biyokimya Dergisi (Turkish Journal of Biochemistry-Turk J Biochem). 33(1), 25-30.

Qureshi N, Saha B., Cotta M.A(2007). Biobutanol production from wheat straw hydrolysate using Clostridium beijerinckii. Bioprocess Biosyst Eng 30:419-427

Qureshi, and Blaschek (2001). Evaluation of recent advances in biobutanol fermentation, upstream, and downstream processing. Bioprocess and Biosystems Engineering 24, 219-226.

Qureshi, N., \& Ezeji, T. C. (2008). Biobutanol, 'a superior biofuel'production from agricultural residues (renewable biomass): recent progress in technology. Biofuels, Bioproducts and Biorefining, 2(4), 319330.

Qureshi, N., Saha, B.C., Hector, R.E., Hughes, S.R., and Cotta, M.A. (2008). Biobutanol production from wheat straw by simultaneous saccharification and fermentation using Clostridium beijerinckii: Part I-Batch fermentation. Biomass and Bioenergy 32, 168-175.

Radakovits, R., Jinkerson, R. E., Darzins, A., \& Posewitz, M. C. (2010). Genetic engineering of algae for enhanced biofuel production. Eukaryotic Cell, 9(4), 486-501.

Ragan, M. A. (1984). < i> Fucus</i>‘lignin': A reassessment. Phytochemistry,23(9), 2029-2032.

Rogers, P., \& Palosaari, N. (1987). Clostridium acetobutylicum mutants that produce butyraldehyde and altered quantities of solvents. Applied and environmental microbiology, 53(12), 2761-2766.

Saha, B. C., Iten, L. B., Cotta, M. A., \& Wu, Y. V. (2005). Dilute acid pretreatment, enzymatic saccharification and fermentation of wheat straw to ethanol. Process Biochemistry, 40(12), 3693-3700.

Samson, R., \& Leduy, A. (1982). Biogas production from anaerobic digestion of Spirulina maxima algal biomass. Biotechnology and bioengineering, 24(8), 1919-1924. 
Sarkar, D., Schilde-Rentschler, L., Löffelhardt-Ruoß, B., \& Ninnemann, H. (2007). An electrofusionmediated improved method for donor-recipient somatic hybridization in potato (Solanum tuberosum L.). Recent Trends in Horticultural Biotechnology. New India Publishing Agency, New Delhi, 129147.

Savage, N. (2011). Fuel options: the ideal biofuel. Nature, 474(7352), S9-S11.

Schenk, P. M., Thomas-Hall, S. R., Stephens, E., Marx, U. C., Mussgnug, J. H., Posten, C. \& Hankamer, B. (2008). Second generation biofuels: high-efficiency microalgae for biodiesel production. Bioenergy Research, 1(1), 20-43.

Schoutens, G. H., Nieuwenhuizen, M. C. H., \& Kossen, N. W. F. (1985). Continuous biobutanol production from whey permeate with immobilized Clostridium beyerinckii LMD 27.6. Applied microbiology and biotechnology, 21(5), 282-286.

Scotia Captial Inc, C. (2010). Biofuels outlook, Equity Research Industry Report.

Scott, M., \& Hwa, T. (2011). Bacterial growth laws and their applications. Current opinion in biotechnology, 22(4), 559-565.

Scurlock, J. (2001). Bioenergy feedstock characteristics.

Shapouri H, Duffield J, Wang M (2002) The energy balance of corn ethanol: an update. In: USDA Agricultural Economic Report No. 814

Sheehan, J., Aden, A., Paustian, K., Killian, K., Brenner, J., Walsh, M., \& Nelson, R. (2003). Energy and environmental aspects of using corn stover for fuel ethanol. Journal of Industrial Ecology, 7(3-4), 117-146.

Sheehan, J., Dunahay, T., Benemann, J., \& Roessler, P. (1998). A look back at the US Department of Energy's aquatic species program: biodiesel from algae (Vol. 328). Golden: National Renewable Energy Laboratory.

Shoemaker, S. P., \& Pierson, M. D. (1976). "Phoenix phenomenon" in the growth of Clostridium perfringens. Applied and environmental microbiology,32(6), 803-807.

Sies, H. (1986). Biochemistry of oxidative stress. Angewandte Chemie International Edition in English, 25(12), 1058-1071.

Sims, R. E., Mabee, W., Saddler, J. N., \& Taylor, M. (2010). An overview of second generation biofuel technologies. Bioresource Technology, 101(6), 1570-1580. 
Singh, J., \& Gu, S. (2010). Commercialization potential of microalgae for biofuels production. Renewable and Sustainable Energy Reviews, 14(9), 2596-2610.

Sorda, G., Banse, M., \& Kemfert, C. (2010). An overview of biofuel policies across the world. Energy policy, 38(11), 6977-6988.

Sticklen, M. B. (2008). Plant genetic engineering for biofuel production: towards affordable cellulosic ethanol. Nature Reviews Genetics, 9(6), 433-443.

Subhadra, B. G., \& Edwards, M. (2011). Coproduct market analysis and water footprint of simulated commercial algal biorefineries. Applied Energy, 88(10), 3515-3523.

Sun, Y., \& Cheng, J. J. (2005). Dilute acid pretreatment of rye straw and bermudagrass for ethanol production. Bioresource technology, 96(14), 1599-1606.

Swana, J., Yang, Y., Behnam, M., \& Thompson, R. (2011). An analysis of net energy production and feedstock availability for biobutanol and bioethanol. Bioresource technology, 102(2), 2112-2117.

Syed, K. (2012).Development of novel clostridial fusants for enhanced biobutanol production. (Master's Theses, Unpublished)

Szulczyk, K. R., \& McCarl, B. A. (2010). Market penetration of biodiesel.Renewable and Sustainable Energy Reviews, 14(8), 2426-2433.

Takagi, M., Abe, S., Suzuki, S., Emert, G., \& Yata, N. (1977). A method for production of alcohol directly from cellulose using cellulase and yeast. Proceedings of Bioconversion of Cellulosic Substances into Energy, Chemicals and Microbial Protein. New Delhi, India, 551-571.

Talebnia, F., Karakashev, D., \& Angelidaki, I. (2010). Production of bioethanol from wheat straw: an overview on pretreatment, hydrolysis and fermentation. Bioresource Technology, 101(13), 4744-4753.

Teixeira, L. C., Linden, J. C., \& Schroeder, H. A. (1999). Optimizing peracetic acid pretreatment conditions for improved simultaneous saccharification and co-fermentation (SSCF) of sugar cane bagasse to ethanol fuel. Renewable Energy, 16(1), 1070-1073.

Thirmal, C., \& Dahman, Y. (2012). Comparisons of existing pretreatment, saccharification, and fermentation processes for butanol production from agricultural residues. The Canadian Journal of Chemical Engineering, 90(3), 745-761.

Thompson, W., Meyer, S., \& Westhoff, P. (2009). How does petroleum price and corn yield volatility affect ethanol markets with and without an ethanol use mandate?. Energy Policy, 37(2), 745-749.

Thukral, V., Dey, S., \& Panda, T. (1989). Multiple pH and temperature optimum of extracellular xylanase from Trichoderma reesei QM 9414. Bioprocess Engineering, 4(1), 43-45. 
Tredici, M. R. (2010). Photobiology of microalgae mass cultures: understanding the tools for the next green revolution. Biofuels, 1(1), 143-162.

Trinh, S., Briolat, V., \& Reysset, G. (2000). Growth Response of $<\mathrm{i}>$ Clostridium perfringens $</ \mathrm{i}>$ to Oxidative Stress. Anaerobe, 6(4), 233-240.

Tseng, C. K. (2004). The past, present and future of phycology in China. In Asian Pacific Phycology in the 21st Century: Prospects and Challenges (pp. 11-20). Springer Netherlands.

Tyner, W. E., Taheripour, F., Zhuang, Q., Birur, D., \& Baldos, U. (2010). Land use changes and consequent $\mathrm{CO} 2$ emissions due to US corn ethanol production: A comprehensive analysis. Department of Agricultural Economics, Purdue University.

Tyner, W., \& Taheripour, F. (2008). Biofuels, policy options, and their implications: Analyses using partial and general equilibrium approaches. Journal of Agricultural \& Food Industrial Organization, $6(2)$.

Vassilev, S. V., Baxter, D., Andersen, L. K., \& Vassileva, C. G. (2010). An overview of the chemical composition of biomass. Fuel, 89(5), 913-933.

Ververis, C., Georghiou, K., Danielidis, D., Hatzinikolaou, D. G., Santas, P., Santas, R., \& Corleti, V. (2007). Cellulose, hemicelluloses, lignin and ash content of some organic materials and their suitability for use as paper pulp supplements. Bioresource Technology, 98(2), 296-301.

Volynets, B., \& Dahman, Y. (2011). Assessment of pretreatments and enzymatic hydrolysis of wheat straw as a sugar source for bioprocess industry. Int J Energy Environ, 2(3), 427-446.

Von Blottnitz, H., \& Curran, M. A. (2007). A review of assessments conducted on bio-ethanol as a transportation fuel from a net energy, greenhouse gas, and environmental life cycle perspective. Journal of cleaner production, 15(7), 607-619.

Walsh, M. E., Daniel, G., Shapouri, H., \& Slinsky, S. P. (2003). Bioenergy crop production in the United States: potential quantities, land use changes, and economic impacts on the agricultural sector. Environmental and Resource Economics, 24(4), 313-333.

Wedum, A. G., Hanel Jr, E., \& Phillips, G. B. (1956). Ultraviolet sterilization in microbiological laboratories. Public health reports, 71(4), 331.

Wijffels, R. H., \& Barbosa, M. J. (2010). An outlook on microalgal biofuels. Science(Washington), 329(5993), 796-799.

Wood, S. M., \& Layzell, D. B. (2003). A Canadian biomass inventory: feedstocks for a bio-based economy. BIOCAP Canada Foundation, 18-24. 
Zandi, M., Zimmerman, W., Gilmour, J., Woolass, S., Adderley, B., Ying, K., \& Hanotu, J. Steel plant $\mathrm{CO} 2$ sequestration using high efficiency micro-algal bioreactor.

Zhao, J., \& Xia, L. (2010). Ethanol production from corn stover hemicellulosic hydrolysate using immobilized recombinant yeast cells. Biochemical Engineering Journal, 49(1), 28-32.

Zhang B, Shahbazi A (2011) Recent Developments in Pretreatment Technologies for Production of Lignocellulosic Biofuels. J Pet Environ Biotechnol 2:108. doi:10.4172/2157-7463.1000108 